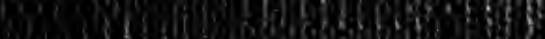

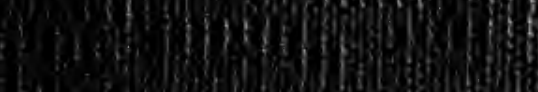

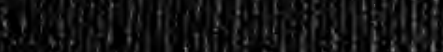
thing. Whas

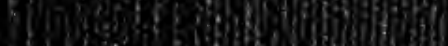

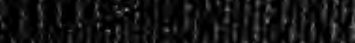

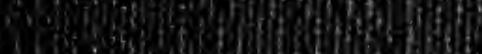

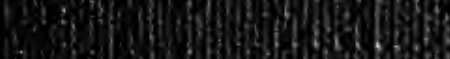

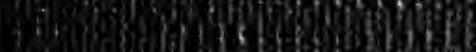

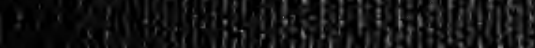
i. s.9. 1.5.

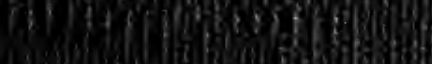

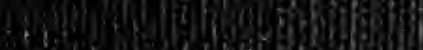

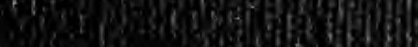

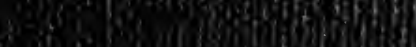
(16)

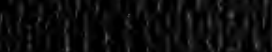
11)

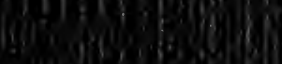
tabo. is (6)

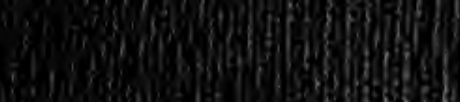
(6)

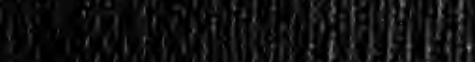

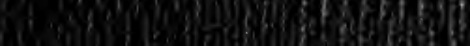

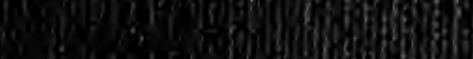
(3)

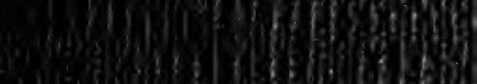
W.

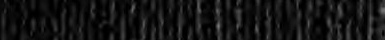
1 if

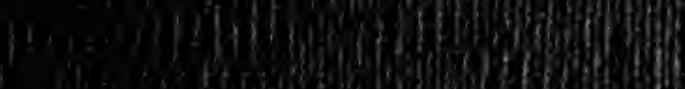

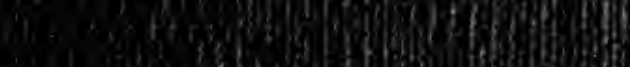

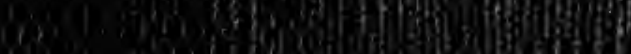

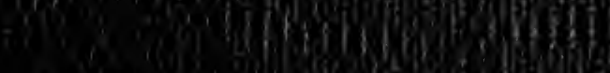

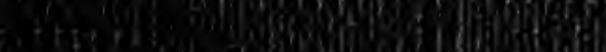







\section{CHINESE MISCELLANIES:}

A COLLECTION OF

\section{ESSAYS AND NOTES.}

By SIR JOHN FRANCIS DAVIS, Bart., K.C.B.

"Colsectanca-Scripta qua ex pluribus excerpta locis in unum lecta sunt."

$$
\text { LONDON : }
$$

JOHN MURRAY, ALBHALRLE STREET.

$$
\text { 186.5. }
$$


J.0.1100:

PRINTEI, LY WUUFALL ANI KINIER,

MILUED LAXE, STRAXIY, Wr.

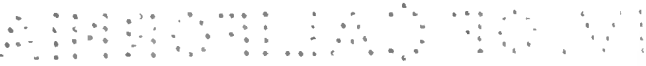




\section{DS \\ 7035
$1029 c$}

\section{PREFACE。}

THE increased facility of access to China and Japanthe combined result of successful war and diplomacy -has augmented the interest which distanco and diffiG culties had tended to keep down. Both countries may now bo reached in little more than six weeks, English law is administered under a Royal Commission on ?.the coast of China, and money coined with the Queen's simage and superseription.

The fow short Articles contained in this Volume may, from their variety, servo for the amusement or information of various readers. Somo aro printed for the first time, and the rest appear with the kind permission in the proprietors of tho. Edinburgh and Quarterly is reviews, and others.

The fears formerly entertained of Enropean nations is in both China and Japan, from the illea that their i prineipal olject was territorial possession, must have J heen greatly allayed by the moderation which lats attended our military suceesses. In the former country, we and our allies, the French, took Peling, the eapital, and then (very mulike Oriental conquerors) left the city to its owners with only the indispensal,le guarantes 
for traty angagenuents ; in the latter, mmelerons uets of trenchery and riolence were fitly punished hy allied anmaments, which withdrew when atonement had been makle. Thus both Gorernments, tho ono an absulute thongh reak sorereignty, the other a fental oligarehy of discordant elements, have been compelled to yield to combince foreign pressure. The aim of the motto on our China medal-rrmis exposeere pacem-has been attained; and now our best policy is to lope for the interual prosperity and efficiency of both Govermments as the most desirable security for our treaty rights. With all their faults they are, in their integral claracter, better than the mock Christian' Taepings of China or the rebellions and assassin Daimios of Japan.

Great as have been our exertions and success, the result was influenced in no small measure by the friendly union and combined action of the Western nations-the conlition of eivilization against barbarism. The following relates to the year 1814:- "So perfect and complete was the ackmowledgement on every side, that each was negotiating for all, that we received officially certified copies of the French and American treaties from M. de Lagrené and Commodore Parker in China, while the Clninese copies were sent us in like manner by Keying. The whole of these negotiations had, howerer, been preceded by official communications from Horgliong to the respective ministers

2 It lias betin pliain, from the first, that lisey were no mure like
Chistials than Malduent was like a Jew. 
of copies of our English treaties already concluded, with all collateral information relating to them." Had the samo weights been thrown into opposite scales -had jealousies and mutual counteraction been the rule-adrantage would certainly havo been taken of it; for the Chinese did their best at first to alienato the French from us, though they were speedily disabused by our homourable allies.

This cordial co-operation may bo traced without diffieulty to the generous and wise policy with which Great Britain extended tho commercial and other rights, which she acquired by her original and unaided war, to all other nations. ${ }^{2}$ Having been tho first to inaugurate the freedom and commmity of trade at home, she followed up that wiso policy abroad by tho moble and generous (and no less wise) course of fighting and negotiating, not for herself only, but for the wholo civilized world. It is thus that peace and mutual good oflices are perpetuated for lialf a century between the most powerful nations; and that, for just fifty ycars, England and France, instead of wasting each other's strength only to end where they legan, have combined their forces and fought side by sicle as closo allies in all parts of the worlil.

1 "China rluring the War and since the l'eace," Vol. ii., froe 89.

" "Lat Granle linetagne dans un

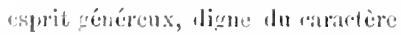

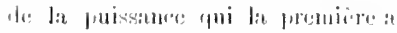

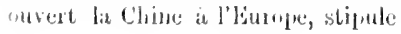

aussi four d'antres nations la lilwerté de faire le commeree dans les rim pon'ts, sons les mêmes comblitimus

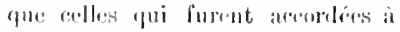

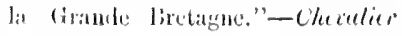
Birusen. 



\section{O NTE N T S.}

I. Calculating Machine-Common Tartar Characteristics of $\begin{array}{lllllllll}\text { Russians and Chinese } & \ldots & \ldots & \ldots & \ldots & \ldots & 1\end{array}$

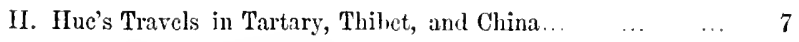

III. The Rise and Progress of Chinese Literature in England $\quad . . \quad 50$

IV. The lioots of the Language, with their Threefold Uses $\quad \ldots \quad 76$

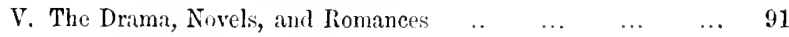

VI. Adrress to the China Branch of the Royal Asiatic Society ... 112

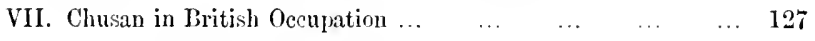

VIII. Analysis of a Work on II usbandry and lotany $\ldots \quad \ldots \quad \ldots 3$

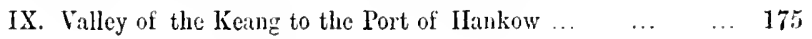





\title{
CHINESE MISCELLANIES.
}

\author{
I. \\ CALCULATING MACHINE. \\ COMMON TARTAR CHARACTERISTTCS OF
}

ERRATA.

Page 61, line 4, for Parker reed I'arkes.

Pitge 16:4, line 12, for longan recel locingun.

both originated in the facilities afforded by the binary division into halves, quarters, eighths, and sixteenths, or eight, four, two, and one.

Their numbers are grnerally written in words at length, that is, unlike the Arabic system of numeration, where the powers or values of the numbers increase or diminish decimally, according to position. I'his inconvenience is got over in calculation, and the denary arithmetic adopted, hy the assistance of a little alpharatus called a Suan-pân, or calenlating dish, having balls 



\section{CHINESE MISCELLANIES.}

\section{I.}

\section{CALCULATING MACHINE.}

\section{COMHON TARTAR CHARACTERISTICS OF \\ RUSSIANS AND CHINESE.}

WITH reference to the science of numbers, it has becn observed of the Chinese arithmetic, as well as of their weights and measures, that they proceed universally on the decimal scale, and that decimal fractions are their vulgur fractions, or those in common use. It is remarkable that the single exception to this exists in their lin, or marketing pound-weight, which, like our own, is divided into sixteen parts; and it is most probable that both originated in the facilities afforded by the binary division into halves, quarters, eighths, and sixteenths, or eight, four, two, and one.

Their numbers are generally written in words at length, that is, unlike the Arabic system of numeration, where the powers or values of the numbers increase or diminish decimally, according to position. T'his inconvenience is got over in calculation, and the denary arithmetic adopted, by the assistance of a little alparatus called a Suân-pân, or calculating dish, having balls 


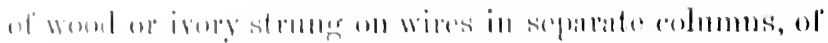

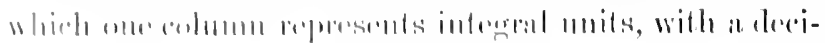

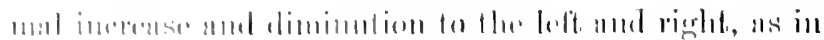

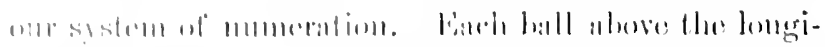

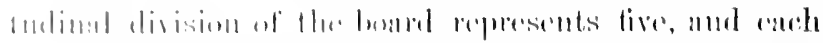

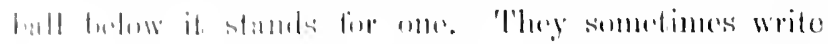

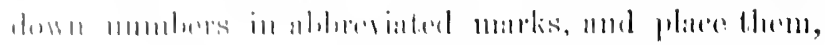

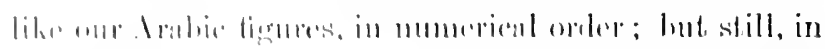

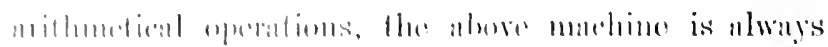

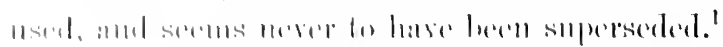

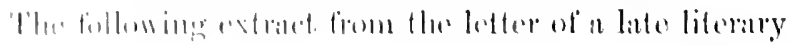

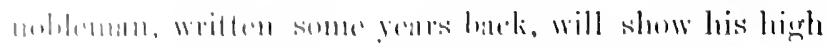

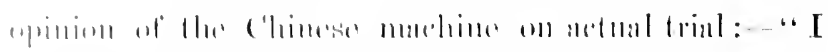

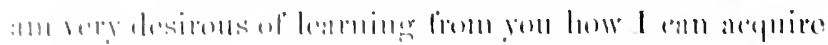

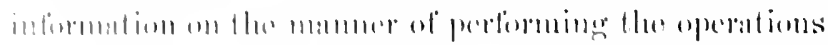

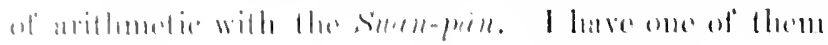

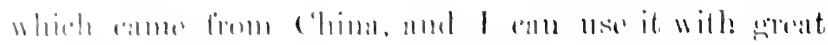

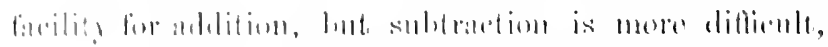

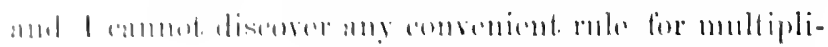

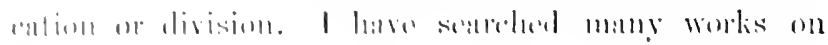

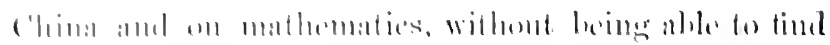

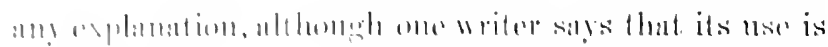
•

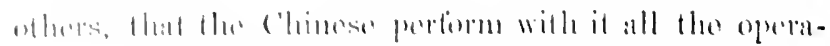

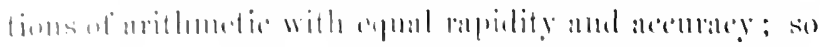

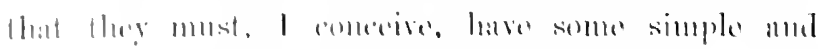

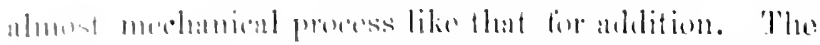

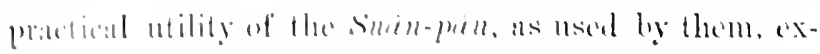

\footnotetext{
I'link, rol. ii.
} 
ceds, beyond all complatison, the fir-famed calenlating machine of Mr. Bathlarge, and is such that the mode of working onght to be generally known, and the instrument itself showth be gencrally adepted. It would save much time and tronble, and womk also have the advantatgo of verifying calconlations which are mate in the ordinary mode. It apjesen's to me to be an olject of great curiosity and importance. We have adopted so much from the chinese alrearly that this would be no great addition to the sim of our oldigntions."

The fioman abaters seems to hatve been used in the same way orcasionally for arithmetial purposes, hat with loose stones in longitudinal divisions, instead of tho monele better modo of stringing balls on wires; but the elenary mumeration would anderar to have been preserved, as with the Chinese. When emmenting on the barlarism of the linssians in the line of Peter the (ireat, Jord Nawanlay states that "their arithuctic was the arithnetio of the dark anes. 'T'le denary notation was

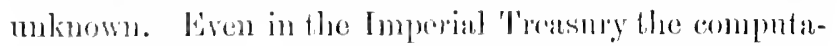
tions were mate by the help of balls stromg on wires." With all due respecet for such an anthority as leord Manambity, it seems to be omly reasomalble to smppose that tho balls strung on wires were noflhing nore nor less than the calculating appontats (of which the very hatse is the decimal sealle), berrowed by the linssians

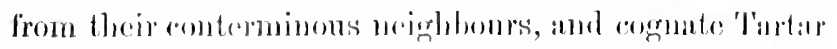
race, the ('hinese, who hal the denary notution, and

1 Concerning whith the late sir calculate when it was to be finishell" R. Pecl askesl, "Conll the machine 
constructed their Suin-pin aecortingly, when our British ancestors were content to walk about with painted slins.

Other Tartar features in the same account of the Russians assimilate them to the Chinese. "The ambassador and the grandees who accompanied him were so gorgeons that all London crowded to stare at them, and so filthy that nobody dared to toneh them. They came to the Court balls dropping pearls and rermin." I This is, though exaggerated, not very unlike some Chinese mandarins, but more like pure (or impure) Tartars." It is further stated, that the young emperor "heard with great interest the royal assent given (in the House of Lords) to a bill for raising $21,500,000$ by land-tax, and learned with amazement that this sum, though larger by one-half than the whole revenue which he could wring from the population of the immense empire of which he was absolute master, was but a small part of what the Commons of England voluntarily sranted every gear to their constitutional king." Thirty rears aro, it was remarked in the same way, with reference to China, "Our own country has proved the fact of the largest amount of direct taxation being leried under a limiter monarchy, and through the delegates of the people themselves; and the English House of Commons las done a great deal more than the Emperor of China conld probably attempt with safety.",

The following argmments were addressed by me, soon

1 Hist."r En England, vol. v., 1. $74 . \quad 3$ China, rol. ii., p. 428.

- See Huc's Travals, infra, p. 13. 
after arriving in China, in 1844, to the Emperor's Minister Keying, in farour of legalizing the trade in opium, and levying a duty on it. This has since been done.

"Your Exeelleney is aware that, in the reign of the Emperor Jien-loong, opium was subjeet, as a medicine, to a duty. The extent of its consumption was then inconsiderable. Subsequently to that, the drug was proLibited, and penalties attached to its consumption; but this prohibition, and these penalties, instead of pre. venting, appear to have inereased the consumption of a noxious article in a wonderful manner, until the value in money of the prohibited opium imported has come greatiy to exceed the amount of the lawful tea exported. This is the experience of China. You will therefore the more readily believe that the experience of England has been the same in reference to all commodities. Opinm, having never been prohibited, is consumed in small quantities, chiefly as a medicine; and the official returns of the last year show that the whole quantity used in England was only 47,432 pounds, or 355 peculs. But, in regard to many other eommodities, England formerly adopted the system of prohibitions and high duties; and these only increased the extent of sinuggling, together with crimes of violenee, while they diminished the revenue; until it was at length found that the fruitless expense of a large preventive foree absorbed much of the amount of duty that conld be collected, while prohibited articles were cousumed more than ever. 
"The disposition of men in matters of mere sensual indulgence attaches additional value to what is diflieult of attaimment. If a commodity be plentiful liy nature, its prohilition creates an artificial difficulty, and therefore an unnatural value. In China, since opium ras prohilited, it has been greedily purchased at an cnormous price; in England, where it has always been lawful, it is gencrally disliked, and scldom used, except as a medicine. England having for many years suffered from the evils of smuggling, as wcll as those of a prerentive force, was at length led to ammul the prohibitions against some commodities, and to lower the duties on others. The consequence has been that smuggling is no longer a gainful employment; and while the duties on useful and innoxious articles of trade hare been diminished, the rerenue consequent on their increased consumption has enormously increased. The total rerenue of England for the last rear was more than $150,000,000$ taels," (about $\$ 50,000,000$, in 1846.)

Keying was too polite to express any doubt of an amount so different from that of the Chincse rerenue; but ho eridently had no small difficulty in belicving it. This unfortunate minister, having failed in negociation with Lord Elgin, was ordered by his unfeeling mastcr to put himself to death ; but the Emperor himself, with a juster fate, died two years after, of chagrin at the burning of lisis summer palace, in requital of the murder of English and French prisoners. 


\section{II.}

\section{HCC'S TRATELS IN TARTARY, THIBET, AND}

\section{CHISA.}

(From the Elinburgh Rericu.)

Abour the end of 18 46 , Mr. Alexander Johnston, son of the late Sir Alexander, and secretary to Her Majesty's Minister Plenipotentiary in China, was fellow-passenger on board the steamer from Hongkong to Ceylon with a French Lazarist Missionary, named Joseph Gabet. It appeared that M. Gabet was then on his way from China to Paris, intending, should ciremmstances be favouralle on his arrival, to bring under the notice of the French Gorernment the ill-treatment which he himsclf and a brother missionary hat experienced at Lhassa, from Ke-shen, resident on the part of the Emperor of China at the Court of the Grand Lama. Some of our readers will recognise in this name that of the Imperial Commissioner who was opposed to Captain Elliot, in 1839, at Canton; and who, on account of the disasters which befel the Chinese arms, was disgraced, plundered, and even condemned to reatl by the Emperor, but has since, with marvellous expordition, contriver to resain nearly all his former honours and credit, and even a great portion of his former wealth, which was colossal, as wo shall see. 
Ur. Johnston found the narrative of M. Galet so curious and interesting, as the most recent and authentic account of 'Thibet in its relation to China, that he noted down the principal hearls at the time, and, on returning to his official post, presented the manuscript to our minister, who forwarded a copy in his despatches to Lord Palmerston.

Nothing more was heard about the matter until the appearance of the two volumes by M. Huc, the companion of M. Gabet in all his adrentures. A more interesting as well as diverting book has seldom issued from the French press. The qualifications of a Humboldt are not to be expected in a missionary priest. And though it should contribute nothing to the geographer or sacant, we might well be grateful for its information regarding countries nearly inaccessible to Europeans; while this information is conveyed in such an inexhaustible strain of good humour and fun, as amply to repay the perusal of any class of readers. In these points M. Hue hears some resemblance to his English namesake, Theodore, as we may almost call him.

Some eight years before the late "Papal Aggression," his Holiness of Rome took a rather smaller liberty with the Emperor of China, by appointing a vicar apostolic to Mongol Tartary. The next thing was to ascertain, if possible, the extent and nature of this gigantic ricariat. However dreadful the intolerance and oppression under which Romish priests groan among us, they were a good deal worse off in the Celestial Empire; and yet there, strange to say, they were as quiet as lambs, and 
the government seldom heard of them, except when some stray missionary was detected and packed off to the coast for foreign shipment. MM. Gabet and Huc, who happened to be residing a little to the north of the Great Wall, in Eastern Tartary, at the commencement of 1844 , were appointed by their spiritual superior to make their way as well as they could through Western Tartary to Lhassa, the capital of Thibet, and the holy see of the Lamas. This might look, at first sight, like taking the bull by the horns. The reader will find, however, to his surprise, that all the opposition they experienced was not ecclesiustical, but lay-not religious, but political; and that, while they received every encouragement and hospitality from the Lama's government, they were baffled, and at length expelled, by the exertions of the Chinese resident or ambassador, Keshen.

In China a Romish bishop or priest was obliged to pass himself off, as well as he could, for a native, in the lay dress of the comtry; but they were now going to enter a nation of priests, and therefore prepared to disguise themselves as Lamas. Off went the tail, which had been elierished ever since their departure from France, leaving the head entirely shaven. A long yellow robe was "fastened on the right side by five gilt buttons: it was drawn round the waist by a red girlle. Over this was worn a short red jacket or waisteoat, without sleeves; or, as they call it in Chinese, "a buck and breast;" having a narrow collar of purple velvet. A yellow hat with broad brim, and surmounted ly a red 
silk lutton, finished ofl their new costume. Their only attemdant was a young Mongol neophyte, named Samdadchiemlat, who is thus deseribed :- "Un nez large et insolemment retroussé, une grande bonche fendue en ligne droite, des lères épaisses et saillantes; un teint fortement lronze, tout contribuait à donner ì sa physionomie nu aspect saurige et dédaignenx." This Tartar Aionis had charge of tro camels and a white horse, which, with a tent, and a dog to guard it, completed the equipment of our adventurous missionaries for the desert. They had no other guide for their route than a compass, and a map of the Chinese empire, pullished in Paris.

The apprehensions expressed by the friends whom they left behind, regarding what they might suffer in the journey to Lhassa, were fully anstrered in the event. M. Gabet well nigh sank under the extreme hardships of this sarage and nomadic life-first across an inhospitable desert, and then over mountains to which the Alps are trifles. From plunder they escaped tolerably free, though the Mongol robbers would seem to be the cirilest in the world. Instead of rudely clapping a pistol to your breast they blandly observe, "Venerable elder brother, I am tired of going a-foot, please to lend me your horse; I am without money, do give me the loan of your purse; it is very cold to-day, let me have the use of your coat." If the venerable elier brother has the charity to comply, he is duly thanked; but if not, the humble appeal is supported by the cudgel; and, should this not do, by something more coercire still. Tery little better than 
the professional robbers were any bands of Chinese soldiers with whom they might have the bad luck to fall in, and whose neighbourhood, therefore, they diligently shumned. During the war with England, on the north-east coast, these ragamuffin troops were so dreaded by their own countrymen that, when the process of civilized warfare came to be known and understood by the Chinese people, the latter often welcomed us as deliverers, and their satisfiction was increased when the public granaries were thrown open to them for nothing. This confirms the dictum of their philosopher Nencins: "If, when you invade a country, the people come to Telcome you with supplies, this can only be becauso you are about to rescue them from fire and water."

Our missionaries hat a characteristic account of the war with England from a Tartar, whom they met in the desert :-

"'What, were all the Tilrtar hanners called together?'-'Yes, all. At first it jassed for a very small natter; every one sath it would never reach us. The troops of fitut (China) went first of all, but they did nothing. The banners of Solon atso marehed, but they could not resist the heat of the south. The Euneror then sent us his sacred order . . . On the sanc day we warched to Peking, and from l'uking we went to Tien-tsin, where we remained three montlss. - "liut dis you fightdid you see the enomy?'- 'No; he diul not dare to show himself. The Chinese protested everywhe that we marched to certain and nuavailing derth.-.' What san you do,' satid they, 'against these' sea nuonsters?-They live in the waters like fish. When least expected, they appear on the surface, and throw combutible balls of iron. When tho bow is bent against them, they take agrin the water like frogs.' Thus it was they tried to frighten us, but we soldiers of the eight banners aro

1 Thus, the Chinese town at Mos- Polo always callis China Ruthry. cow is ealled Kituignod, atul dlarers. 
ignorant of fear. The Emperor hal provided each learler a Lama instructed in melicine, and initiated in all the saered auguries. They would cure us of the diseases of elimate, and save us from the magie of the sea monsters-what, then, need we fear? The rebels, on hearing that the invincihle troops of Tokekr approached, were seized with alarm, and asked for peace. The sacred master (shing-rlu) of his immense merey granted it, and then we returned to our pastures and to the charge of our tloeks.'"

It is linown for certain that when the British force had reached Nanking and the Grand Canal in 1812, the Emperor so fully expected a risit at Peking that he stationed a force at Tien-tsin, as stated by the Tartar, and made every preparation to decamp into Tartary himself. In the confusion of packing up, some dexterous persons contrived to rob the treasury of sereral millions, and to this day the culprits have nerer been detected. The parties considered responsible, howerer, were, with all their relations and commexions, made answerable for the restoration of the treasure to the third and fourth generation. Without adverting to this circumstance, M. Huc observes, in another place, that during the progress of the war with the English, " nous savions que l'empereur était anx abois, et qu'il ne sarait où prendre l'argent nécessaire pour empêcher de mourir de faim une poignée de soldats qui étaient chargés de veiller à l'intégrité du territoire Chinois."

The most distinguished hero, sent by the Emperor to exterminate the English during our war, was a Chinese general named Yang. This man had enticed the unfortunate Mahommedan chief, Jehanghir, in the war with Cashgar, to trust himself in his hands, and then sent him in a cage to Pehing, where, after amusing 
the Emperor, like a trapped rat or mouse, he was cruelly put to death. M. Hue heard the following account of Yang's tacties:-

"Aussitôt que l'action s'éngageait, il faisait deux grands nnends à sa barbe pour n'en être pas embarrassé ; puis il se portait à l'arrière de ses troupes. Là, armé d'un long sabre, il ponssait ses solulats an combat, et massacrait impitoyablement ceux qui avaient la lâcheté de reculer. Cette façon de commander une armée paraitra bien bizarre; mais ceux qui ont vécu parmi les Chinois y verront que le génie militaire du général Yang était basé sur la connaissance de ses soldats."

His tactics certainly did not succeed ag'ainst onr troops, and as he nerer made his appearance, it is supposed that he occupied his favourite place of honour at the tail of the rear guard, and led gallantly in a retreat. "Nous arons demandé," says M. Huc, "à plusieurs mandarins pourquoi le Batourou Yang n'avait pas exterminé les Anglais : tous nous ont répondu qu'il on acait cu compression."

We have a terrible description in these rolumes of Tartar uncleanliness, and several of the details on this subject are quite unpresentable. The dogma of the transmigration of souls acts, it seems, with some as a protection to the vermin with which they are infested. The interior of their tents is repulsive and almost insupportable to those unaceustomed to the odours that prevail there. Dirty as the Chinese may be, their northern neighbours far exeeed them; the former at least have taken it upon themselves to settle the question, by calling the latter Chow 'Th-tsze, "stinking Tartars," as systematically as they call Europeans "foreign devils." 
This clever and indefitigahle, lut not too serupulous, race, have nearly displaced the Manchors in their original country to the nortl-east of the Great Wall, and almost as far as the river Saghalien.' The Chinese are the men of husiness and shopkeepers in all towns, and have very little merey on the eomparatively lonest and simple Tartars. It is impossible to help laughing at the stories of their ingenious raseality. They are in fact the cheraliers dindustric-the Scapins and Mascurilles of Eastern Asia. M. Huc, in the following passage, gives an account of their tricks, which might have applied rery closely to the way in which they treated our poor sailors in the sonth of China:--

"When the Mongols, an honest and ingenuous race as erer" were, arrive in a trading town, they are immerliately surrounded by Chinese, who carry them off home as it were by force. Tea is prepared, their beasts looked to, a thom-and little services rendered. They are caressed, flattered, magnetised in short. The Mongols, who have nothing of duplicity in their own charaeter, and suspect none in others, end by leing mored and touched by all these kimlnesses. They take in solver earnest all the professions of devotion and fraternity with which they are plied, and, in a word, persuade themselves that they have had the good fortune to meet with leople thescan confide in. Aware, moreover, of their own inaptitude for commercial dealings, they are enchanted at finding brothersAhaton, as they call it-who are so kind as to undertake to buy and sell for them. A good dinner gratis, which is served in a room to the rear, always ends by persuading them of the entire devotion of the Chinese confederacy. 'If these people were interested,' sass the honest Tartar to himself, "if they wished to plunder me, they would hardly give me such a coot dinner for nothing; they would not expend so much money on me.' It is generally at this first repast that the Chinese luing into play all that their character eombines of villany and trickery. Once in pos. session of the poor Tartar, he never escapes. They serve him with

1 "NIaintenant on a beau parcourir la Mantchourie jusqu'au Heuve Amour. C'est tout comme si on voyagait dans quelque province de Chine." 
spirits in exeess, and make him drink till he is fudlled. Thus they keep possession of their vietim for three or four days, nerer losing sight of him, making him smoke, drink, and eat; while they sell his live stock, and purchase for him whatever he may want, charging him generally double or triple for every thing."

M. Hue puts in a strong light that appropriation to themselves of Manchow, or Eastern Tartary (the country of their last conquerors), which has been effected by the Chinese within something more than a century, and to which we have already alluded. In a map of this country, constructed by the Jesuits, Père Duhalde states his reason for inserting the Tartar names, and not the Chinese. "Of what use," says he, "would it be to a traceller in Manchouria to know that the river Saghalien is called by the Chinese Ih-loung-Keang (river of the Black Dragon), since he has no business with them, and the Tartars, with whom he has to deal, know nothing of this name?" "This olservation might be true in the time of Kanghy," says M. Hue, "when it was made, but the very opposite is the fact at present; for the traveller in Manchouria now fincls that he has to deal with China, and it is of the Iri-lommgKeang that he hears, and not of the Saghalien." In our own colonies, the rapidly increasing numbers and wealth of the Chinese, where they exist, are apt to give them a degree of presumption which, with the aid of their vices, might make them troullesome, were it not for the wholesome dread they entertain of European power, wherever they happen to be really acquainted with it.

M. Huc explains how Thibet, and even Mongol 
Tirtary, to a considerable extent, is a nation of Lamas. He says he may venture to assert that in Mongolia they form at least a third of the whole population. In almost every family, with the exception of the eldest son, who remains "homme noir," " all the rest of the males are destined to be Lamas. Nothing can be more obrious than the fact that, in China Proper, Buddhism and its temples are in ruins, and the priests left in a starring condition; while, on the other hand, the gorernment gives erery encouragement to the Lamas in Tartary. The double object is said to be thus to impose a cheek on the growth of the population, and at the same time render that population as little warlike as possible. The remembrance of the ancient power of the Mongols haunts the court of Peking. They were once masters of the empire, and, to diminish the chances of a new invasion, the study is now to weaken them by all possible means.

With this large proportion of the male population condemned to celibacy, M. Huc gires us the following reasons for his thinking that polygamy, under all the eircumstances, is the best thing for the Mongol Tartars. ${ }^{2}$ It seems generally to have existed in the pastoral and nomadic state.

1 This is a distinguishing term for the laity, who wear their black hair, while the Lamas shave the whole head.

2 M. Huc is here treating of the Mongol Tartars; not of the Thibetians. Father Regis, in his memoir annexed to Duhalde, speaking of the polyandry of Thibet, states expressly that "the Tartars atmit of no such irregularity." T'umer, Mooreroft, and Skinner found a plurality of lusbands common at Teshoo-Loomboo, Lixlak, and on 
"La polygamie, aholie par l'Evangile, et contraire en soi an bonheur et à la concorde de la famille, doit être considérée peut-être comme un bien pour les Tartares. Tu l'état actuel de leur société, clle est comme une barrière opposée au libertinage et à la corruption des moeurs. Le célibat étant imposé aux Lamas, et la classe de ceux qui se rasent la tête et vivent dans les lamaseries étant si nombreuse, si les filles ne trouvaient pas ì se placer dans les familles en qualité d'épouses secondaires, il est facile de conceroir les lésordres qui naîtraient de cette multiplicité de jeunes persomnes sans soutien, et abandonnées à elles-mèmes."

The married state, howerer, is any thing but the conjugal, in the literal and derivative sense of the term. The lussiband can send back the lady to her parents without even assigning a reason. He is quits by the oxen, the sheep, and the horses which he was obliged to give as the marriage present; and the parents, it seems, can sell the same merchandise over again to a second biuder.

Onr travellers in their progress westward had to cross the Yellow Rirer more than once where it makes a bend northwards throngh the Great Wall and back again, enclosing in this curve an area of some three degrees square, the miserally waste and sandy comntry of the Ortous. Unhappily for the pour missionaries, this

the Ilimalayas. We fouml it too in Ceylon, as Cirear har fomm it in Jitain. Jirbsures as the custom secus to 11 , and inexplicable by any supposed disproportion of the sexws, we pereive no more satisfartory explasuation of its existence anomg the Thilutians, than among the Niars in Malalar. There is no incompatilility, it is true, betwern follynamy aml jolyandry. The Nair, we surpet, does not linit limself to lis copatrenary wife: ane in the Mibutharat, althomuh Drauparli is the wife of the live I'andus brothers, some of them, - if nut all, - end Arjunat especially, have several other wives. but, in case M. IIte fommel polyantry at Lhasea, in either form, the omision is macountable. It must have hecen as ereat a novelty to a barolo:an, ats the romom of $\mathrm{Mr}$. Morlyston's "live mincort." 
ruthless and nugainly stream (which a late emperor justly called "China's sorrow") was in its frequent condition of overflow. and we have a pitiable description of the miseries endured by themselves and their camels, of all beasts the least adapted to deal with floods. The waters of the Yellow River, pure and clear at their sonre anong the Thibet mountains, do not assume their muddy tinge until they reach the alluvial tracts of the Ortous, where they spread over thousands of acres during the inumbations, altogether concealing the bed of the stream. Being from this point always nearly on a level with the combry through which they flow, this defect of encaissement is the cause of disastrous accidents, when the rapid stream is swollen by melting snows near its source. The same relocity, which charges the river thickly with comminuted soil, prerents its deposition on the passage until it reaches the provinces of IIonan and Keangnan, where the actual bed of the river is now higher than a great portion of the immense plain through which it runs. This evil being continually agrarated by further depositions of mud, a fearful catastrophe seems to overhang that unfortunate region; at the same time that the constant repair of the dikes taxes the ingenuity, while it exhansts the treasury, of the Chinese govermment. Our pleinotentiary offered to the minister Keying, a relation of the Emperor, the aid of English engineers in an emogency where science conld scarcely fail of beneficial results; but he shook his hoad, and said he dared not eren mention the subject. 
The personal observations of M. Hnc settle the question as to the real natme and amount of what is called the "Great Wall" towards the west:-

"We had occasion," he says, "to cross it at more than fifteen different points, and sereral times we travelled for whole days in the line of its direction, and kept it constantly in view. often, in lieu of those doulle turreted walls which exist near Peking, we met with notling move than a simple piece of masonry, aul sometimes a molest rampart of eirth. We even oceasionally saw their famons wall reduced to its most simple exjression, and composed solely of some heaped stones." 1

It may be observed, with reference to the land frontiers of the Chinese empire on the west, that the authority of the Emperor, instead of abruptly encomtering the hard ontline of an entirely independent authority, is shadowed off by something of a blended jurisdiction. "Il existe daus le Kin-son, et smr les frontières de la province de Sise-Teloumen, plusienrs peuplades qui se gonvernent ainsi elles-mémes, et d'après des lois spéciales. Toutes portent la denomination de Tom-sse, à laquelle on ajonte le nom de fianille te lenr chef on sonverain." (P. 3li.) The find in another place that this prevails to the sonth-west, on the horders of Ava. "On the ontskirts of the empire, towards the west, are a number of tewns or stations,

1 "Père Gerbillon informs us, that heyome the Villow River, to its western extrenity (or for full one-litilf of its total lentlo), the wall is chictly a monend of carth or gravel, about tiftean lect in lud int, with only oestsinat towers of brick. Matren Molos silence corncerning it maty therofore be atc- comber for on the sulnosition that, hatring secu only this immerfect portion, la. alid not leem it an oljeret of sulicient coriusity to leserve preticular notice, without the neascity of imateining that le entered Chine to the south of bles gretet burier."-The chiness, vol. i. 
called Ton-sse, or 'mative juristictions,' where the aborigines are more or less independent, and where there is, in fiact, a linel of divided authority, each party heing inmuliately subject to its own chiefs. This is particularly true of the Lolós." - The Chinese, vol. i.

It is an odd iesult of on war with China, that something of the same princinle shonld have been established ly treaty at the Five Ports of trade on the opposite side of the empire. British subjects are there entirely independent of the Chinese law, and goremed by their own consuls, who act under ordinances framed by the governor and legislative conncil of Honghong, confirmed by Her Majesty in Comeil. The inference from the frepuencr of these "native jurisdictions" is, that Clinese law, as adminisiered towats foreigners, becomes intolerahle; so at least it proved at Canton.

It wonld be a pity to spoil the following passage by a translation :-

"Xrtre auberiste, un Chinois pur-sang, pour nous donner une premve de sa sagureité, nom- lemamla sans teroriverser si nons neétions pas Anglais ;

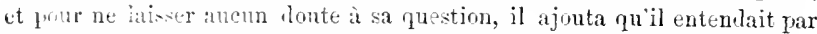
lug-lieti les ' liables marins' qui raisaient la guere a Canton.- 'Non, nous ne sommes pas Anglais; nous autres, nous ne sommes diables l'aueunc façon, ni le mer, ni de terre.' Cn désururé rint fort à propos détruire le manais effet de cette intervellation intempestive.- "Toi, dit-il

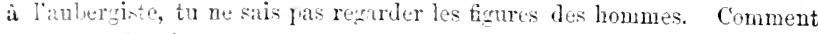
osus-tu prétendre que ces cens li sont rles Yunf-louri-tse? Est-ce que tu ne sitis pas que ceux-ci ont les yeux tout blens, et les cheveux tout rouges :- C'est juste, dit l'auber riste, je n'avais pas bien réféchi. - 'Non, certainement, ajontanues-nous, tu n'arais pas bien rétéchi. Crois-tu que des monstres marins lourraicnt, commes nous, vire sur terre, et seraient catable- d'aller a cheral ?'- 'Oh, cest juste, cot lien cela ; les Iur-kie-li, dit-un, nosent jumais quitter la wer; aussitut qu ils montent ì terre, ils 
tremblent et meurent comme les poissons qu'on met hor's de l'eau.' On parla beaucoup des mceurs et du caractère des 'diables marins,' et d'après tout ee qui en fut dit, il demeura demontré que nous n'étions pas du tout de la même race."

These volumes contain the most detailed and complete account of the Lamas that we remember erer to have met with; and they confirm, on the authority of these Romish priests themselves, the astonishing resemblance that exists between the external rites and institutions of Buddhism and those of the Clutrch of Rome. Besides celibacy, fasting, and prayers for the dead, there are enshrined relics, holy water, incense, candles in broad day, rosaries of beads comted in praying, worship of saints, processions, and a monastic habit resembling that of the mendicant orders. Althongh our worthy missionaries call the images of Buddhism idtels, and the Romish idols imuges, we do not think the distinction is morth much, and therefore may throw in this item with the rest; the more especially as, on the summury principle of inereucm viam aut furiam the commandment against idol worship has been thrust bodily out of their Decalogne by the Romanists, as may be seen from any copy of the missal. It is remarkalile that these very missionaries had an image made for their own adoration, from a European model, at a place on their journey where a lunge image of Buddha had just been cast, and sent off to Lhassil. (Vol. i., p. 41.) Thus the olject of their worship was a molten image, the work not only of men's but Pagan hands, employed indiflerently for either Buddhism or Romanism. 
It is at once curions, and an instrnctive lesson to mprejuliced minds, to observe that M. Huc, while he indulges in pleasantries at the expense of the Buddhists, entirely forepets how applicable his sarcasmes are to his own side of the question. After deseribing an assembly in a college of Lamas, where the explamations given by the priests or professors on certain points of their religion proved as rague and incomprehensible as the thing to lie explained, he adds, "On est, du reste, conraincu que la sublimité d'une doetrine est en raison directe de son obscurité et de son impénétrabilité." Let us only suppose M. Huc expounding to these Lamas the dogma of transubstantiation, and adding, in testimony of its truth, that St. Ignatius Loyola, with eyesight sharpened by faith, declared he actually saw the farinaceous substance changing itself into flesh. "Les hommes," observes our author in another place, "sont partout les mêmes !"

The jolies in which M. Hne indulges against the devotees and recluses of Buddhism are similar to what have been repeated a thousand times with reference to those of Romanism :-

"Ce jeune Lama de vingt-riuatre ans était un gros gaillard bien membré, et dont la lourde et épraisse figure l'accusait de faire dans son étroit réduit une forte consommation de beurre. Nous ne pouvions janais le roir mettre le nez à la porte de sa case, sans songer à ce rat de La Fontaine, qui jar dévotion s'était retiré dans un fromage de Hollande."

The monasteries of the Lamas, resembling as they do in so many respects those of the Romanists, differ from them on some few points. The members are all subject to the same rule and the same discipline; but they do 
not seem to live to the same extent in community, and exclusive rights of property prevail among them. Our missionaries passed some months in these establishments. Besides his Holiness the Supreme Lama at Lhassa, there are Grand Lamas, who derive their investiture from lim, and descend from past ages in uninterrupted succession. With reference to one of these it is observed :-

"Si la personne du Grand Lama nous frappa peu, il n'en fut pas ainsi de son costume, qui était rigoureusement celui des évêques; il prortait sur sa tête une mitre jaune; un long bâton en forme de crosse (crusic $r$ ) était dans sa main droite; et ses épaules étaient recouvertes d'un manteau en taffetas violet, retenu sur sa poitrine par une arratfe, et scmblalule en tont à une chape. Dans la guite, nous aurons à signaler de nombrenx rapports entre le eulte catholique et les érémonies Lamanesques." (Vol. ii., 1. 101.)

\section{Huc afterwards recapitulates as follows:-}

"La crosse, la mitre, la Dahnatique, la ehape ou pluvial, que les grands Lanas portent en voyage, ou lorsqu'ils font quelque cérémonie hors du temple; l'office à denx chrours, la psalmodie, les exoreismes, l'encensoir soutenu par cinq chânes, ct pouvant s'ouvrir et se feriner ì volonté; les bénédlictions données par les Lamas en étenlant la main droite sur la tête des fidèles ; le cliatrelet, le célibat ecelésiastique, les retraites spirituelles, le culte des saints, les jeûnes, les processions, les litanies, l'ean bénite; voilà autant de riphorts que les boudlisistes ont avec nous."

He might have added that they likewise have a goddess, whom they eall T'ien-hou, literally regine coli, "Queen of Heaten," lont witlı a different legend.

Our anthor very naturally endeavours to persuade himself and his reaters that by some process of diablevie these things have heen borrowed from his own Churelı; but why shonld we do such violence to the sulject, when there is the much easier, more intelligible, and more straightforward course of deriving both from some- 
thing older than either ; and remaining persuaded, as most of us must have heen long ago, that the Pagan rites and Pontifex Maximus of the modern Rome represent, in ontward fashion, the Paganism and Pontifex Maximus of the ancient? Strange to say, instead of blinking the matter, a sort of parallel has often been studiously preserved and paraded, as when the Pantheon, the temple of " all the gods," was consecrated by Pope Boniface to "all the saints." Is it necessary for us to compare the amnual sprinkling of horses with holy water to the like process at the Circensian gamesthe costly gifts at Loretto to the like gifts at Delphithe nums to the rirgines sanctie of old Rome-the shrines of "Maria in triviis" to the like rural shrines of more ancient idols-the flagellants (whose self-discipline Sancho so dexterously mitigated in his own case) to the practices of the priests of Isis? In rumning the parallel the only difficulty is where to stop. It is impossible to look at the innumerable rotive pictures and tablets which conceal, without adorning, the walls and pillars of many a church at Rome, and not to think of

\section{" nam posse merleri}

Picta docet templis multa tabella tuis." 1

To instance a higher department of art-as the old artist, in painting his Tenus, is said to have combined "each look that charm'd him in the fair of Greece," so the Italian painters have sometimes immortalized the features of their own mistresses in pictures of saints and martyrs, intended to adoru churches.

1 Midáleton's Letter from Rome. 
In its modern traits, as well as in its ancient, Buddhism maintains its resemblance to Romanism. Prodigies and miracles of constant occurrence come to the aid of the priesthood, and maintain their influence over the stupid multitude. Some of the instances adduced are palpable cases of ingenious jugglery; but M. Huc, with characteristic facility, belieres in the miracle, while he attributes it to the agency of the deril :-

"Une philosophie purement humaine rejettera sans doute des faits semblables, ou les mettra sans balaneer sur le compte des fourberies lamanesques. Pour nous, missionaires eatholiques, nous croyons que le grand menteur qui trompa autrefois nos premiers parents dans le paralis terrestre, poursuit toujours dans le monde son système de mensonge ; celui qui avait la puissance de soutenir dans les airs Simon le Magicien, peut bien eneore anjourl'hui parler aux hommes par la bouche d'un enfant, afin d'entretenir la foi de ses alorateurs."

Whaterer Protestants may think and say of the means by which the Romish Church has maintained and extended its influence orer the masses of mankind, it is impossible to deny the thorough linowledge of human nature on which all its measures have been caleulated. The same causes which have aided it so longr against the reforms of a purer faith are likely to aid it much longer ; and we really see very little chance of a change. The priestly array, the lighted taper, and the histrionic pantomime, are aided by smoking censers, graven or molten images, and all the paraplermalia by which so many temples of so many different roligions have heon hefore distinguished. We entircly arrece with M. Hue, that the Romish Cluurch has a fair ficld for proselytism in the rast regions where budthism at present prevails. 
In extcrual forms the transition is the easiest possible; and during his short residence at Lhassa he remarked, -. Il nous somblait tomjonrs que la beanté de nos cérenonies eut aud puissamment sur ce penple, si aride de tont ce qui tient an culte exterienr."

If the new system camot be made to supersede the old, it may at least be grafted upon it, as experience has alreaty proved at onr own colony of Ceylon; for Romanism has sometimes been satisfied with a part, where the whole was muattainalle. In a recent work by Sir Emerson Tennent, he olserves of the early converts in that island to the Romish Church, "there is no reason to douht that, along with the profession of the new faitl, the majority of them, like the Singalese of the rresent lay, cherished, with still closer attachment, the superstitions of Buddhism ;" and he attributes the ease of their external conversion to "the attractions of a

I In a hook which had belonged was found this estimate, written on to a Romish missionary in China the ty-leaf in Italian :-

"Numbers included under different known religions:-

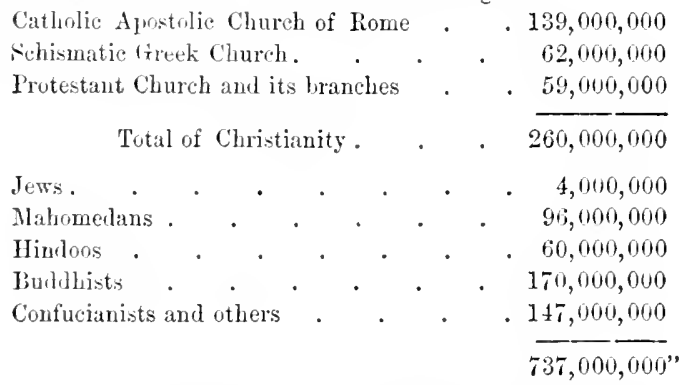

The number of Buddhists is Lhassa, and from the confines of probably not over-rated, considering Siberia to Siam. that they extend from Japan to 
religion which, in point of pomp and magnificence, surpassed, without materially differing from, the pageantry and processions with which they were accustomed to celebrate the festivals of their own national worship." We may, however, charitably and reasonably suppose that the present emissaries of Rome rould stop short of the complaisant conformity of their Jesuit predecessors, who, according to the Abbé Dubois, "conducted the images of the Virgin and Saviour on trimmphal cars, imitated from the orgies of Juggemath, and introdneed the daneers of the Brahminical rites into the ceremonial of the Church."

After eighteen months of mingled residence and journeyings throngh the immense tract which intervenes between the neighbourhood of Peking and Lhassa, MM. Hue and Gabet reached the eapital of Thibet in as very weary and exhansted state. 'The snowy range of monntains which formed the latter portion of their ronte was passed with a caravan, which is periodically collected as a protoetion against robbers; and the miscries and privations which they enchred had wellnigh proved fiatal to M. Gabet, though both travellers were in the prine of life-one thirty-two, and the other only thirty-seven. Scarcely settled in the lodging where thoy hat installed themselves, tronbles not less harassing, thongh of another kind, were to bo encomitered. "Apris les peines physiques, cétait lo tour des sonffrances morales." As fiur as rested with the native govermment of the comntry, they might lones have remained mmolested to exercise their zeal at tho 
head-quatrters of lindthism; hut obstades arose in a direction whing they were hartly prepared to anticipate. 'The minister of the Emperor of China resides at the Comrt of the supreme Lamia, something like the Austrian ambasisator at Rome, lut with a rastly greater and more melividen inthence. His spies were the first to detect the intruders; and he succeeded at length, notwitlstanding the farour and kindness shown to them ly the temporal Regent of Thibet, in effecting their explsion from the country. The whole nalrative is extremely curions, and, in fact, gives a better insight into the real relations existing between Peking and Lhassa than any other source within our reach.

In addition to the numerous and striking analogies which have been traced between the rites of the Lamas and the Romish worship, M. Huc olsserves that "Rome and Lhassa, the Pope and the Supreme Lama, might also furnish points of resemblance full of interest." The Thihetian government is altogcther ecclesiastical. The Talé or Dalé-Lama is its political and religious head. When he dies, or, as the Buldhists say, transmigrates, his indestructible personification is continued in a chilh, chosen by the great Lamas, distinguished as Inoutonlitur, whose sacerdotal rank is inferior only to that of the Grand Lama, and whom, therefore, we may compare to the cardinals. The present Dale-Lama is only nine years of age, and his three predecessors had none of them reached their majority; a circumstance which seems to indicate foul play, and which was in fact expressly attributed to treachery on the part of the 
administration of Thibet, rested chiefly in the hands of a functionary styled Nomekhan, during the Grand Lama's minority.

A party at Lhassa opposed to this Nomeklan applied secretly, in the year 1844, for the interference of the Emperor of China, who is sufficiently ready to extend his infuence on all occasions, in Thibet and elsewhere. The person selected to proceed as ambassador to Thibet, and overtmen the ill-acquired power of the Nomelihan, was Keshen, who only abont fonr years before had been mined by the result of his negotiations at Canton : but whose energy and talents appear still to have been appreciated by the Emperor's government, and whose failure might possibly have met with palliation and excuse in the still worse failures of his successors in the Sonth. On reaching Lhassa, Keshen took his measures in concert with those opposed to the Nomekahn. That high functionary was arrested; when, to aroid torture, he at length confessed to the guilt of haring taken three lices from the Grand Lama, or, in other work, haring eansed his transmigration three times by violence. To this confession the seals of Keshen and the other parties were aftixed, and it was transmitted by a special courier to Pekinger.

"Trois mois après, la equitale du Thilet etait plongée dans une affreuse

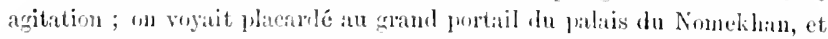
dans les rues frincipales de la ville, un édit impérial en trois lingtues sm

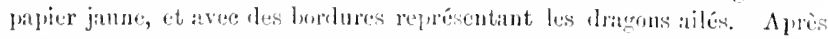

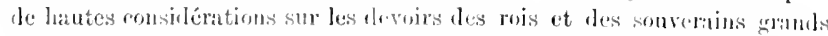

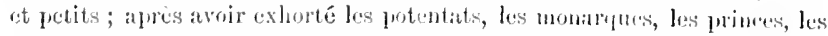

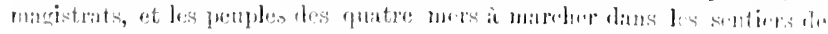

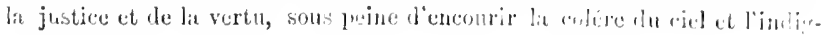




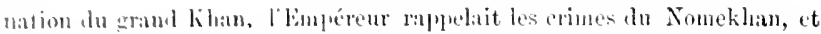

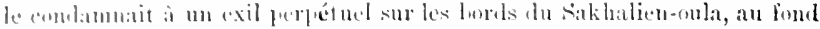

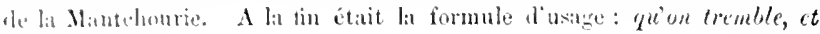
quion wheisise!"

Silch an munsual sight as this Imperial edict on the grates of their coromer exeited a general insurrection amonir the 'Thibetians of Lhassa. At half a league's listanee is a Collere of Lamas, composed of some thousands. 'These armed themselves at random, and cante down like an aralanche, denouncing death to Feshen and the Chinese. They carried by assault the residenee of the ambassator, who, however, was not to be fomnd. They next attacked those who had acted with him, and sacrificed more than one to their fury. They released the condemned Nomekhan, who, howerer. hat not the spirit to arail himself of the occasion. "Il avait" (sayss M. Huc) "la láche énergie d'un assassin, et non l'audace d'un séditieux."

The next morning, the Lamas were again agitated like a hive of beos, and again swamed down upon Lhassa. But Keshen had profited by the interval, and liss mensmes were taken. A formidable array of Clinese and Thibetian troops barred their passage; and the Lamas, whose trade was not fighting, betook themselves to their cells and their books, and were glad to aroid the consequences of their temerity in an inmediate lesumption of their clerical character. In a few days, the Somelinan, who had thrown away his only chance. was on his way "comme mu monton" to Tantary-while lieshen, clated with his triumph, shomed a disposition to extend the penalties to his re- 
puted accomplices in guilt. The ministers of the local government, howerer, thonght that Chinese influence had done enongh, and the ambassador had the prudence to forbear. The new Nomekhm was selected from the Lamas of the greatest eminence in the country; but as the choice fell on a youth of only eighteen, a Regent was appointed in the person of the chief laton, or minister. This individual soon showed that his first eare was to provide barrier's against the ambition and encroachments of the Chinese ambassador, who had so boldly taken advantage of the weakness of the Thibetian goremment to usurp its powers, and extend the pretensions of his master the Emperor.

Things were in this state on the arrival of our two missionaries, who, after some weeks of ummolested residence, began to flatter themselves that they might pass molserved. They were one day scated at their lodging in conversation with a Lama well rersed in Buddhistic learning, when a well-dressed Chinese suddenly mate his appearance, and expressed a strong desire to inspect any merchandise they might have to dispose of. They in vain declared they were not merchants: he was not satisficel, and in the midst of the discussion arrived a secoml Chinese, and then a third; after which, the number of risitors was soon swelled to five, by the "pleatrance of two bamas in rich silk scarfs. They all joincel in a multitute of purs-

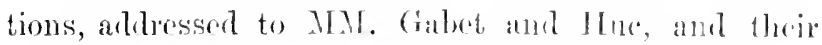
looks wore directed on all sides, in a minnto rxaminilation of the contents of the dwelling. The the at leneth 
took their kave, promising to return, and left our missionaries in an uncomfortahle state, justly thinking that the pretended chanee visit looked like a concerted mealsme, and that thoir new fricmls hat very much the nplearnence of either spies or swindlers.

When dimner was over, two ont of the late five reappeincel, and at once ammomeed that the Regent desired to see the missionaries; "and that young man," - saic they, pointing to their fathful Tartar attendant Samduhlirmba, who ered them with no very friendly looks-_." he must come too." The authorities must be obeyed, and they set out together towards the palace of the Regent. On their arrival, they were conducted through a court and passages, crowded with Thibctians and Chinese, to a large room, at the end of which was seated the Regent, with his legs crossed upon a thick cushion corered with a tiger's skin. He was a man of about fifty, stout, and remarliably fair, with a most intelligent and benerolent countenance. The strangers were invited to seat themselves on a bench covered with red carpet to their right. We must give what follows in the original :

"Anssitót que nous fûmes assis, le Régent se mit à nous eonsidérer lons-tenus en silence, et avce une attention minuticuss. Il penchait sa tìte tantót à lroite, tautôt à gaı che, et nous examinait l'une façon moitié moquense, et moitic bienveiliante. Cette espece de gantomime uous parnt a la tin si drite, que noms ne pumes nous em lêrer de rire. 'IBon! dimesnous en Frazcais, et it voix laxe, ce nonsien larait assez bon enfant; notre atfire ira lien. - Ah : Ait le léerent, d'un ton plein l'affiljilité,

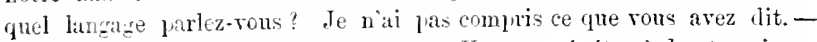
Nuns parlons le langage de notre 1nys. - Toyons, répétez à hante voix ce que rous arez lrononcé tout has. - Nous dirions: 'Ce monsieur parait assez bon cufant. - Vous autres, eomprenez-rous ce langage?' ajouta-t-il, en se 
tournant vers ceux qui se tenaient debout derrière lui. Ils sinclinèrent tous ensemble, et répondirent qu'ils ne comprenaient pas. "Yons voyez, personne ici n'entend le langage de rotre pays; traduisez ros paroles en Thibétuin.' Nons disions que, dans la physionomie du premier Kalon, il y avait beancoup de bonté. - 'Ah! oui, rous trourez que j'ai de la bonté ? Cependant, je suis très-méchant. N'est ce pas que je suis tres-méchant? demanda-t-il à ses gens. Cenx-ci se mirent à sourire, et ne repondirent pas. 'Tous avez raison, continua le Régent, je suis bon, car liu bonté est le devoir d'un Kílon. Je dois être lon envers mon peuple, et aussi envers les étrangers." "

This good-natured functionary assured the missionaries that he had sent for them merely in consequence of the contractictory reports in circulation, and without the least wish to molest them. After having found, to his surprise, that they could express themselves in the witten characters of China, Tartary, and Thibet, and having satisfied himself as to the nature of their pursuits, he informed them that the Chinese resident was himself going to question them. He advised that they should frankly state their history, and added that they might depend upon his protection, for it was himself who governed the country. As he took his departure, the noise of the gong annomed the approach of Keshen. The experiente of our travellers made them anticipate a less agrecalle interview in this quarter; but they serewed their conrage up to the sticking place, determined that, as Christians, as missiomaries, and as Fronchmen, they would not kneel to any body ; and they bule their supire and neoplyyte Samedudchiember confess his frith, if the occasion shond require. 'The portrat of the eeleliated mandarin must be given at full length. 
" Kichun, quoique aqué d'une soixantaine l'années, nous parnt plein de fores ot de vigueur. Sa tignre est, sans contredit, la phus nohle, la filus gracieuse et la plus spirituelle que nous ayous jamais reneontrée farmi les Chinois. Aussitit que nous lui enmes tiré notre chapeau, en lui fitisant une courbette de la meilleure fiaçon quil nous fìt gnssible. 'C'est bien, cest hien, nous dit-il, suivez ros usages; on ma dit que vous larlez correctement le languge de Péking : je lésire eauser un instant avec rous. Nous commettons heaucoup de fautes en parlant, mais ta mereilleuse intellizenee saura suppléer à l'obscurité de notre parole. - En rérité, voilà du pur Pékinois! Vous autres Français, vous avez une srante facilité pour toutes les seiences: Vous êtes Frangais, nest-ce-pas?-Uui, noms sommes Francais. - Oh: je connais les Français ; antrefois il y en avait heaucoup à Péking, j’en royais quelques-uns.- Tu as dû en eomnâtre aussi à Can. ton, quand tu étais commissaire impérial.' - Ce souvenir fit froneer le sourcil à notre juge; il puisa dans sa tabatiere une abonlante puise de talac. 'et la renitla de très mauvaise humeur.- 'Oui, e'est mai, j'ai ru beaucoup d'Européens à Canton. Tous êtes de la réligion du Seigneur du Ciel, n’est-ce pas?-Certainement; nous sommes même prédicateurs de cette réligion.- Je le sais, je le sais; rous êtes, sans doute, venus ici pour prêcher cette réligion?-Nous n'arons pas d'autre but.-Arez-rous déji parcouru un grand nombre de jays ?- Nous avons parcouru toute la Chine, toute la Tartarie, et maintenant nous roici dans la capitale du Thilet.-Chez qui avez-rous logé quand vous étiez en Cline?-Nous ne répronlons pas ì des questions de ce genre.-Et si je rous le commande ?Nous ne pourrons pas ohéir.' (Ici le juge dépité frappa un rude coup de poing sur la tahle.) - Tu sais, Jui dimes-nons, que les Chrétiens n'ont pas leur ; pourqui donc chercher à nous intimiler ?-Uu arez-rous appris le Chinois?-En Chine.-Dans quel endroit?-En peu partout.- Et le Tartare, le sarez-rous? Uu l'avez-rous appris?-En Mongolie, dans la terre des herbes." "

The firm bearing of MII. Hue and Gabet was properly respected by Keshen, who, horrever, did not treat with the same ceremony their Tartar attendant Samdadchiombre, on finding he was a subject of China. He ordered him peremptorily to kneel, and in that attitude

1 The Chinese gererally take snuff out of a small hottle, but Kesken probably required larger suprlies, and hal a silver hox or ressel at his side _ " rase en argent." 
obtained from him his history, which might have gone far to compromise the unfortunate squire, but for his comnection with the two missionaries. Keshen's character appears to considerable advantage throughout this narrative. Eneroaching and overbaring towards the Thibetian gorermment, according to his supposed duty to his sovereign, his personal demeanom to the two travellers proved his dne appreciation of the European character, no doubt the result of his experience at Canton. The lateness of the hour put an end to the andience, and our missionaries had an immediate interview, followed by a supper, with their kind friend the Pegent, whose solicitude may fairly be attributed as much to his jealonsy of the Chinese resident as his sympatlyy for the strangers. At this interview appeared as interpreter, on account of his knowledge of the Chinese language (the medium most familiar to the missiomaries), a certain Nahomedan ehief of the Mussulmans of Cashmere, resident at Lhassa. This little incident shows our increased vicinity to the Chinese empire, since Gholal, Singh, ruler of Cashmere, became our tributary, and bound himself in the treaty with Lord Hardinge to transmit ammally a dozen fine shawls, and a certain number of shawl goats, in acknowledgment of Britisl supremacy.

The greatest canse of anxiety to the Regent, and the ciremonstance most likely to compromise the missionaries, proved to be the supposed possession of maps of the comtry, constructed ly thenselies. It would secm, according to our anthor, that this fear originated 
sine the visit of our comntryman Mooreroft, who, acombling to the Thibrtiens, introdnced himself at Jhassa as a mative of Cashmere. They stated that, alter a resillence of some year's, he took lis departure, but was murdered on his way to Ladak. Among his eflects were a number of maps and desions which he had executed during his stay in this comtry ; and lience the fear of map-makers. The truth, lowever, is, that this farl has been of long standing, in China at least, where the common notion of an Englishman is that of a bipes implumis who goes about making maps of the comtry, with an express view to futme conquest. Keying, the most liberal Chinese we have ever had to leal with, was in a perpetual fidget about the coast survey, carried on since the peace by that able officer, Captain Collinson, between Hongkong and Shanghae, and plagned H.M.'s plenipotentiary incessantly on the sulject. It was useless to protest that nothing but the safety of our traders was in view; that the commercial treaty was altogether futile withont the safe navigation of the seas by our merchant ressels; and it became necessary at once to cut the matter short by saying that the commanders of H.M.'s ships must obey any orders they received from their government in the prosecution of their lawful business.

1 The time and plice of Monrrroft"s death near Balkh, as related by Professor Wilon, have been confirmed llorough repeited notices gathered by liarnes and others during our oecupation of Cabul and the adjacent countries, and thure is no doubt of the fact. Mooreroft's resillence for twelve years, from 1826 to 1838 , at Lhassa, withont being heard of, directly or indirectly, by any European, whether in India, Nepaul, China, or Russia, is incredible on the face of it. 
Maps of the comntry our missionaries had, but they were not autograph, nor even manuscript. A grand scrutiny took place before Keshen :-

" 'We are fortunate,' said the travellers to the Chinese Minister, 'to find you here. In your absenee it might have been impossible to convince the authorities of Thibet that we did not construct these maps ourselves; but to a person of your information-to one so well acquainted with European matters-it is easy to pereeive that these maps are not our work.' Keshen appeared greatly Hattered by the compliment. - 'It is evident at once,' said he, 'that these are printed maps. Look,' he adderl to the Regent, 'the maps, instear of being male by these persons, were printel in the eountry of France. You could not perceive that; but I have heen long aecustomed to distingnish the various objects which come from the west.",

Solvuntur risu tubule.-This incident was of more use to the missionaries, and relieved them more completely from the clond which hat hung over them, than anything else that conkt have occurred. The only fear and anxiety of the Regent himself was effectually removen, and from being virtually prisoners, and their baggage miler seal, they returned in a sort of ovation to their lodging. It did not seem unreasonable for them, unter all the eircumstances, to hope that they might remain unmolested in the country. This appeared still more probalble after their friend the Regent hat allowed them to take up their quarters in a house helonging to the Government, where they established a chapel, and where they were visited by both 'Thilhetians and Chinese, some of whom manifested no disinclination towards the Romish worship. Enongh has heen shown to prove that, in external rites, these is not a great deal of difference; and there are, besides, certain 
(iremustances which give the Papal emissaries great practical atrantages over Protestant missionaries. Whaterer may be the evils or scandals attending celibacy in the Romish Church (and Dr. Dens' miscalled "Theology" proves its dangers in the confessional), it has leen very useful to them in the case of foreign missions, and in the exploration of untried regions or new fields of action. The very undertaking we are considering could never have been accomplished by Protestant clergrmen encumbered with the "impedimenta" of wires and families. When a missionary is nominated from England, the prospect of a provision, supposing him to be single, generally induces him to marry, and he fixes himself down, say at one of the fire ports of China, for perhaps his life, with the very moderate prospect of converting the empire from a place corresponding to one of our seaports. If he dies prematurely, which is often the case, the funds which sent lim ont become charged with the maintenance of those whom he leaves behind, and we need only look over the accounts of the Propagation Society to see that a very considerable amount of their funds (most justly and unaroidably, we admit,) are swallowed up annually in this way.

The interval of prosperity now enjoyed by our travellers, but destined to be too soon interrupted, was varied by some interesting and unreserved conversations with Keshen. His Canton recollections seemed to haunt him. "Kichan nous demanda des nourelles de Palmerston; s'il était toujours chargé des affaires 
étrangères." He gave them a graphic and perfectly true description of the absolute power of the Chinese sovereign :-

“ "Notre Emperenr nous dit, Voilà qui est blane. Nons nous prosternons, et nous répondons, Oni, voilà qui est blane. Il nous montre ensuite le même objet, et nous dit, Voilà qui est noir. Nous nous jrosternons le noureau et nous répondons, Oui, voilà qui est noir. - Mais enfin, si vous disiez qu'un olyjet ne saurait être à la fois blane et noir?-L'Jinpereur dirait peut-être à celui qui anrait ce eourage, Tu as raison : mais en même temps il le ferait étrangler ou décapiter.'"

Keshen was a high authority on this sulject, for he had been one of the Emperor's privy councillors.

M. Hue persuades himself, naturally enongh, perhaps, that the Clinese resident in Lhassa became jealous of the progress made by himself and M. Gabet among the Thibetians, and therefore determined on bringing about their departure from the country; but any Chinese functionary in his position would have deemed such a measure necessary, and a mere act of prudence as concened himself, considering he served a master who, as we have just seen, treats his servants in so truenlent a style, even when they have reason on their side. Keshen had already been once condemmed to death himself.

" Un jour l'ambassadeur Kichun nous fit apleler, et après maintes cajoleries il finit jar nous dire que le Thilnet était un pays trop froid, trop pauve pour nous, et qu'il fallait songer à retourner dans notre royaume de Franee. Kichan nous adressa ces paroles avee me sorte de laisser-aller et d'abauton, comme s'il ent supposé qu'il n'y avait la moindre oljection ì faire. Nous lui dematulâts si, en parlant ainsi, il entemlait nous donner un eonseil on un ordre? - 'L'un et l'autre,' nons rélondit-il froidement."

They in vain urged that they were not (Chinese sulhjeets and therefore disclaimed his assinmer anthority 
orer them in Thilnet. The conference was abruptly terminated by their hing informed that they must prepare themselves to quit the comtry. They went at once to their friend the Regent, who, in words at least, seemed to impress them with the notion that he did not consider their departure absolutely depended on the will of the Chinese resident. The habitual insincerity of Asiatics renders them very ready to say anything that may be agreeahle to their hearers, and their love of ease makes them willing to aroid mpleasant discnssions. It is very probable that the Regent was jealous of Keshen; but we camnot go quite the length of imagining, with II. Hne, that a ready compliance with the determination of the Chinese minister on the part of himself and M. Gabet became necessary, "de peur de compromettre le Régent, et de devenir, peut-être, la cause de fichenses dissensions entre la Chine et le Thibet." We are persuaded that whaterer circmmstances may occur to occasion a war between Thiliet and China, it will not be for such a cause as this. M. Huc must before now have become sensible that he equally miscalculated in another quarter. "Dans notre candeur, nous imaginions que le gonvernement Français ne rerrait pas arec indifférence cette prétension inouie de la Chine, qui ose poursuirre de ses outrages le Christianisme et le nom Français jusque chez les peuples étrangers, et à plus de mille lienes loin de Péking." China has long exercised the same sort of power (or influence) in countries very far west of Lhassa, and therefore more distant from Peking. 
It was certainly a stipulation in 1845 , between M. de Lagrené, the French minister, and Keying, that the Romish religion should no longer be snbject to persecution in China; and Sir John Daris lost no time in obtaining for Protestants whatever privileges were to be accorded to Romanists. In 1847, however, two Romish bishops in partibus were found in the interior, and immediately sent off to the coast, whence they found their way to Hongkong, indignant at what seemed to them so direct a violation of treaties. The Chinese government declared that the privileges in question were only intended for the Five Ports where Europeans were permitted to reside, and that they did not extend to admitting the teachers of Christianity into the interior.

We altogether concur with II. Hnc on one point. If the two missionaries were to quit Lhassa, they might at least have been allowed to leare it in the readiest and easiest way. Within three weeks' jommey was the frontier of Bengal, whence it was their wish to proceed to Calcutta. Jut no-Chinese fears and jealousies had decreed otherwise. The same absurd precaution which had cansed certain emissaries from Russia to be conducted by a romdabont course from Kiachta to Peking, doomen our poor missionaries to trecail from Lhassa through Alpine passes to the frontier of China, and from thence to Canton-a weary course of abont cirht months. They protested in vain, and declared thint they wonld denomee this ernel measure to the French government. Keshen was inflexille, observing that he 
must remember what was expected of him by the Emporor, and talie care of his own head.

A srood escort, however, was provided, and every care taken for the welfare of our trarellers. A mandarin of respectable military rank, and fifteen Chinese soldiers, were charged with their safe conduct by Keshen in preson, who, moreover, in a most edifying oration, recorded by .I. Huc, pointed out their respective duties; and truly the undertaling before them was not a light one, as the description of the journey to the Chinese frontier (where the present work concludes) will easily show. In this almost impassable tract of country we may discover the real cause of the separation, for so many ages, of China from the Western world; for mountains of nearly the same Alpine character extend all the war from Tartary southwards to Yumman and the frontiers of the Burmese Empire. The hardships of the present journey, undertaken under all possible advantages, lilled no less than three mandarins, that is, their conductor and two others who joined them on the route. We must obserre, howerer, that the former had been invalided from his duties on account of swelled legs and other, probally dropsical, symptoms, brought on $b y$ the abuse of stimulating liquors. We must give our anthor's description of this mandarin's separation from his Thibetian wife, as it is a specimen of $\mathrm{M}$. Huc's style :-

"Avant de monter à cheral, une Thibétaine rigoureusement membrée et assez proprement vêtue se presenta : c'était la femme de Ly-kouo-ngan. Il l'arait épousée depuis six ans, et il allait l'abandonner pour toujours. Ces deux conjugales moitiés ne derant plus se revoir, il était bien juste 
qu'au moment d'une si déehirante séparation, il y eut quelques mots d'adieu. La chose se fit en publique, et de lit manière suirante.- 'Toilà que nous partons, dit le mari ; toi, demeure ici, assise en fraix dans ta chambre. - Ta-t-en tout doucement, répondit l'épouse; ra-t-en tont doucement, et prends bien garde aux enflures de tes jambes. Elle mit ensuite une main derant ses yeux, comme pour faire croire qu'elle pleurait. - Tiens, dit le Paeificatenr des royaumes ${ }^{1}$ en se tommant rezs nous; elles sont drôles ees femmes Thibétaines; je lui laisse une maison solideneut hâtie, et puis une foule de meulles presque tont neufs, et voili qu'elle s'avise de pleurer! Fst-ce qu'elle n'est pas contente comme cela?'- Après ces adieux si pleins d'onction et de tendresse, tout le monde nonta it cheval."

One word more about Kioshen. A most striking trait of Clinese claracter is recorded by M. Hue, just as lhe is on the point of departure. We have seen the cireumstances under which our missionaries took leare of the imperial representative at Lhassa. Whatever lhe might think or say on the occasion, they, at least, had just cause to consider themselves treated by him with umnecessary harshness; if not for their remoral from 'Thibet, at least for their remoral by the way of China, instcad of Bengal. Notwithstanding all this, he drow them aside at their last interview, and said, confidentially,_-" "I shall soon be on the way to China myself; that I may not be overcharged with eflects on my departure, I send two large chests by this opportunity; they are covered with Thibet cowskins" (showing us at the same time how they were lettered); "I recommend these two cases to your special care. When you reach the relays at night, let then be deposited in your sleeping apartment; and when you arrive at the eapital of Sise chuen province, deliver them to the care

1 A play on his Chinese name.

"The lake of Thibet, beuf is lung poil, figured in Turner's coullatey. 
of the riecroy." Thus, when a Chinese officer, a countryman and nomine of his own, was going the sime jonruley, he preferred entrusting this treasure (for such 110 doult it was) to two poor European missionaries, whom he had injured, rather than to a Chinese mandarin of respectatle station, who was, in a great measure, his own dependent. He had often sail that Le admired and respected the European probity, and this was a practical proof of it. M. Huc rery justly adds,-- "Cette marque de confiance nous fit plaisir: c'était un homage rendu à la probité des Chrétiens, et en mème temps une satire bien amère du caractère Chinois."

Some time after Keshen's disgrace, there appeared at Hongkong the copy of a Peking gazette, which detailed the circumstances of his sentence, and gave the amount of his registered property. The two ministers commissioned on the occasion reported that they found in his house, or at least in his possession, 682 Chinese pounds of gold, being about 14,560 English ounces; but of silver the enormous amount was $17,940,000$ tack, which is more than six millions sterling, or as nearly as possible the whole amount of indemnity paid to England on account of the war, including the ransom of Canton. Keshen might thus truly be said to hare "paid for the war." But, as if this were not enough, his women were sold by auction (Mr. Rolins nerer had such an opportunity), and when he reached the capital from Canton, he was without the necessaries of life, though the emperor soon packed 
him off to Elee, the Celestial Siberia. ${ }^{1}$ After all this, it was rather cool, when his services were wanted, to appoint him resident at Lhassa; where, howerer, he soon contrived to do something towares repairing his broken fortunes, by helping himself to the gold and precious stones in which Thibet abounds. The two chests in charge of the missionaries were, no donbt, an instalment of his remittances to China; and he is now viceroy of the province of Ssc-chuen (whither he sent the chests), one of the largest of the empire, being equal in area to all France. This strange history is not unlike that of many a minister of the Celestial Empire. ${ }^{2}$

Our missionaries make no pretension to learning: and are credulons in proportion. But their notices of what they saw are curions, and, we believe, truthful. We will conclude with two very extraordinary Thibetian castoms, which we do not remember in Turner : though it must be olserved that, while they did not reach Ladak or the Indian frontier, neither did Turner reach Lhassa or the Chinese.

"Les femmes Thilútrines se sommettent dans lenr toilette a un usage, ou plutôt à une règle incroyialle, et sims donte unique dirns le monde. Avant de sortir de leur maisons, elles se frottent le visige avec une espèce

I M. IIne has the true version of the story. "Limprimeur, dans sa patcruelle mansuétude, lui fit gràce de sa vie, et se contentia de le dégruder de tous ses titres, de lui retirer tontes ses acorations, de contisquar ses biens, de riser sa ratison, de fitire vendre ses femmes à l'encan, et de l'envoyer en exile au fond de la Tartaric."

2 The unfortunate keying, who negotiater the Treaty of Nanking, beinesent in 1858 to stop, by nexotiation, if possible, the puoserss of bond blgin, and having failed, was ordered to jut limsile to deatle, whild he lid, lecing wistorets of 70 years of age. 
de vernis noir et gluant, assez semblable a de la confiture le raisin. Comme elles ont pour lut le se rembe lailes et hilleuses, alles répandent sur leur fice ce fard dégontant ì tort et i trivers, et se harbouillent de manicre à ne plus ressembler à des créitures lamuanes."

It is certainly sometling altowether new to find any race of women with the amhition "de se rendre laides et lideuses," but it must he an amazing simplification of the business of the toilet. The only wonder is that such a custom wis ever submitted to, when, as M. Huc states, a certain Nomelihin, or Lama-king of the country, imposed it on the female part of the community, as a corrective of their morals and a protection to their rirtue.

"Afn d'arrêter les progrès d’une license qui était devenu presque générale, le Nomekhan publia un élit, par lequel il était defenulu aux femmes de prâtre en pululic, à moins de se barhouiller la figure de la façon que nous avons déjà dite. De hantes consilérations morales et religieuses motivaient cette loi étrange, et menaçaient les réfractaires des peines les plus serires, et surtout de la colire te le lindignation de Bouddha."

Nothing but a hierarchy, or rather, a nation of priests, could erer have succeded in so monstrous a scheme of moral or religious discipline, more unnatural than the numneries of Promanism. "One need not sure look frightful, though one's dead."

The second strange custom is a Thibetian salutation of respect, more alssurd eren than the " nose-rubbing," with which the Esquimaux greet their friends. M. Hue describes it by the terms "tirer la langue," which can only mean "putting ont the tongue." We have read that the New Zealanders have a hahit of expressing their hatred or definnce of their enemies by the same elegant gesture, and for such a purpose it might seem 
sufficiently significant and appropriate among sarages: but how a people, at least semi-civilized, like the Thibetians, could ever have fallen upon such a mode of signifying respect, is altogether marvellous. It goes far at least to prove the purely conventional nature of all such signs, when the very opposite movements have been adopted by different nations to denote the same thing. If to uncorer the head be, in Europe, a marls of respect, it is precisely the reverse in China: and though to salute with either the right or left land be a nearly indifferent matter among us, a salutation with the left is so deadly an insult with Nahomedans in the East, as to have been instantly answered with a stab or a shot. For this reason, the native commissioned officers of our Indian army, in giving the military salnte, confined it to the sword held in the right hand, and did not at the same time raise the leit hand to the forehead.

Since the ruler of the Valley of Cashmere has become a tributary to the British crown, circumstances must occasionally bring us into contact with the Chinese govermment through 'Thibet. From the first conclusion of the treaty letween Gholab Singh and the GovernorGeneral of India, Lord Hardinge, with the foresight of a statesman, turned his attention to the accomplishment of two most desirable oljects: first, the exact aseertainment and definition of the bonndaries between Cashmere and the Ladak territory ; and secontly, the continuation of the same trale letween the territory now dependent on the British government, and Landak, 
as hat heen hefore estallished by treaty between Cashmere and Latdik. We fomml, in fact, such a treaty existing, by which teal and shawl-wool were to be transmitted to Cashmere and the Punjal, by the Ladak roan ; and persons proceeding from Ladak to China, or from C'hina to Laduk, were not to be obstructed on the way. That no means might be left nutried, Lord Hardinge engaged the services of H.רI.'s plenipotentiary in Chinil, to communicate with the minister of the Emperor, Kering, on the sulject, and obtain, if possible, the alpointment of Chinese or Thibetian eommissioners to mect our own on the new frontier of India. The land distances to be traversed in negotiation were enormons. From Canton to Peking was 1,200 miles, and from Peling to our frontier more than 2,000. Various and Protean were the shifts and changes by which Keying, in Chinese fashion, endeavoured, to elude all concern or responsibility in the matter. Among others was this highly ungeographical objection: "The trading with Thibet would not be in conformity with the maritime treaty, as it is not included in the Five Ports." When convinced of the real nature of this non-sequitur, Keying admitted that the traders on the Indian frontier might carry on a commerce entirely distinct from that of the English merchants, who repair to the Five Ports of China ; and he engaged "faithfully to transmit to his sovereign the whole tenor

1 Our manufactory of tea in Kunaon is so promising, that we may one day supply it to Thibet and Chinese Tartary, where the consumption is very large. 
of the correspondence." He would hardly fail to do so, being aware that all Lord Hardinge's commmications must at last reach Peking through Thibet, and betray any concealment of the subject. Three commissioners were appointed by Lord Hardinge in 1817, to enter the Thibetian teritory, and endeavour to settle the frontier boundaries, if possible. Other objects were combined with the principal one. Lientenant Strachey, one of the commissioners, was instructed to follow up his previous researches in Ngari, and penetrate through Gurdokh to the Lake Manasarowar, and so eastward, as far as practicable, through Darjeeling or Bhotan to the British provinces. That officer has printed an interesting narrative of his first journey, in 1846 , proving the rigours of those Alpine regions to be precisely corresponding to the experience of MII. Huc and Gabet. 


\section{III.}

\section{THE RISE MYD PROGRESS OF CHLSESE LITERITLRE IN ENGLAND,}

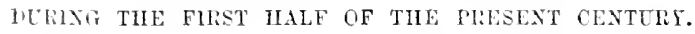

Cincse literature among us is almost entirely the slowth of the present century. In the arrangement of the cmbassy of Earl Macartney, at the close of the last, not an Englishman could be found who knew anything of the language; and, when that nobleman was appointed to proceed to Peling, we were somewhat discrectitably reduced to the necessity of engaging the services of two Romish priests to aid the important oljects of the mission in the quality of interpreters. Sir John Barrow obserred, with reference to that emlassy, that its "intercourse and communications were committed to the timidity and ignorance of two native Chinese missionaries, who had been edncated in the Collexe de Propagandia Fide" at Rome. Then it was that the advisability of remedying this state of ignorance lecame first apparent. The English are not often disposed to waste their time and energies on anything that does not offer a fair prospect of advantage in some way or other; but when once they begin the progress is commonly rapid. Sir George Staunton, at that time a boy of twelve years of age, and attached to 
the mission as page to the ambassador, was judiciously devoted to the acquisition of that "great mnknown," the Chinese langnage. There never was a stronger instance of the omne innotum pro mirifico. It was then supposed that every separate character stood apart, independent and per se, and had to be committed to memory without any associating link to aid its retention. This absurd assumption of conrse repelled and revolted all approaches even to the threshold. Time and knowledge dispelled the delusion, and young Staunton made such progress in the course of a very few years as led to his obtaining a nomination to the East India Conpany's Service in China, at that time considered a certain and rapid road to fortume, and having then in its ranks one or two seions of the house of Baring.

The tirst fruit of Sir George Stannton's lahours was a translation of the Penal Cokle of Clina, published in 1810. This system of criminal law received a high meed of praise from no less a julge than Sir James Mackintosh, who, in his critique in the Edinlumple Rerisu, pronounced it to he well adapted to the existing condition of the Chinese people-the true test of the fitness of all laws. When Hongkong fell to us by conquest as a crown colony, I fonnd no better way of goveruing the Chinese popmlation (liy far the majority) than by the "Penal Code," a copy of which always lay before the jurlge when Chinese were concemerl. Every village was placed muler the charge of its chlers, who inenred considerable responsibility on account of those under their control. 
The practical importance of the linguage being now dnly estimated, anotlyer labourer appeared in the person of Morrison, who proceded as missionary to China about the year 1808, and was soon engaged in the service of the East India Company as interpreter, remaining under their liberal patronage until his death in 1834. The quiet and leisme which this afiorded him were favourable to study, and he improsed his opportunities to the production of works ealculated to teach the language, and therefore most wanted at the time. Some nseful dialognes and a grammar were the forerunners of his chief work, the Dictionary; but the Grammar was undertaken too soon, consisting of phrases more English than Chinese in construction, and has been since far surpassed by the Grammar of Rémusat, which owed much to the "Notitiu Linque Sinice" of Prémare, then a MIS. in the King of France's library, but since printed. The Dictionary could not have been executed but by the liberal $\therefore \therefore$ of the East India Company, who from first to last expended on it some ten thousand pounds, between its commencement in 1817 and its completion in 1823. All the characters had to be expressly cut in metal, and when the Dictionary was concluded this raluable fount remained in China to print numerous other works; above all, the "Chinese Repository" in twenty rolumes.

The Dictionary of Dr. IIorrison still remains as the ereatest monument of literary labour in the cause of the Chinese language. There are six large quarto volumes. The first three are from the Dictionary of Kanghr, and follow the Clinese classification by the Roots. Had the 
plan been eompleted as it commeneed, the work would have been an encyelopedia, but it proved too vast, and was eurtailed. The two next volumes are according to the phonetie arrangement, or the sounds of the charaeters. The sixth and last volume is a not very eopious dietionary, English and Chinese. I myself derived considerable oecupation and advantage from correcting nearly the whole of the work for the press.

While this Dictionary was yet in embryo, or only begum to be eompiled, I went out in 1813, more than half a century ago, to join the same station with Sir George Staunton; and it is now almost ludierous to eall to mind the meagre helps which then existed for learning Chinese.

Professor Wilson well described, similar obstaeles to our first students in Sanserit. "The diffieulty of aequiring the knowledge of a diffienlt language without any other appliances and means than grammars and lexicons in the language itself, and preeeptors ignorant of English, and unfamiliar with our notions of elementary tuition, ean be eoneeired by none but those who have been placed in similar cireumstances."

The first step was to eopy out the whole of Morrison's grammar in MS., and then the whole of his "Dialogues." The East India Company liberally presented me with two MS. dietionaries, one of them Latin and Chinese, and the other Chinese and Latin, both compiled by Romish missionaries, and copied by a Chinese convert. It so happened that in that very same year, 
181:3, a huge folio wals printed at Paris by order of Napoleon I., being the Dictionary of P. Basile de Glemona. Notwithstanling its immense sizc, weighing as it did, with the binding, between thirty and forty pounds, the number of words was not very large; and thongly it was duly sent out from Fingland, I preferred using the more liandy dictionaries in MS. A new labourer in the same fich arrived about that time in the person of the Rer. W. Milue. He soon attained to a very considerable proficiency in the linguage, and not long after printed a translation of the shin!l-yn, or Sacred Elict, which is, in fact, a complete exposition of Clinese moral and political principles. Had Dr. Milne long survived, he would have been a rery distinguished Sinologue, being a person of much talent and sound judgment.

About the same time the Rer. Mr. Narshman, a Baptist missionary at Serampore, turned his attention to the same pursuit, and without the adrantage of a residence in the country acquired sufficient knowledge to publish a very respectable work, called "Claris Sinica," in one large quarto volume.

The embassy of Lord Amherst was despatched to Peking in 1816, some twenty-three years after that of Earl Macartney, and the impulse which had been communicated by the first mission became ausmented by the second. A new and practical turn was given to Chinese studies. The translations which had been made by the Romish missionaries of classical and philosophical works were sufficient to prove that to 
Europeans these possessed little real value. After acquiring the style of official papers, the new students turned their attention to a more attractive pursuit, the popular literature of the Chinese, as contained in their Drama, their Norels and Romances, and their Poetry. The French, meanwhile, were not idle. Without any material interests in China comparable to our own, M. Abel Rémusat had been appointed Professor of the Chinese language in Paris.

Haring thus enumerated the earliest pioneers of this branch of Asiatic literature among ns, we may proceed first to review the philolofical works which appeared in aid of Chinese studies, and then conclude with short critical notices of the translutions which have served to elucidate and exemplify this entirely new field of oriental literature. The late Professor Wilson took an extensive retrospect of all branches except the Chinese, and he then took occasion to call on the late Sir George Staunton and myself to perform our part. I alone survive to respond, however imperfectly, to the call, and with reference to the professor's illustrious memory may add-

\section{"Et fungar inani munere."}

The first printed dictionary appeared at Paris in 1813, being the one already mentioned as issued under the order of Napoleon I. This risantic monmment of typography, in above eleven humbed folio pages, loses some of its nsefulness from loulk alone, and lats nome of the Clinese character in the definitions; nothing except the words to be defined, and those in an 
immense trpe; while the dictionaries which have been sinee printed in China abound with examples in the original character. The arrangement is under the Roots, perhaps the best of all, thongh sometimes it is phonetie eren in mative dictionaries.

There is a singular parallel to the first printed Chinese dictionary in the first printed Sanscrit grammar. "It formed," says Professor Wilson, "an immense volume, extending to a thousand quarto pages. This is in great part ascribable to the size of the Sanscrit types employed, which, in the first stages of Sanscrit printing in India, were of umecessarily gigantic dimensions." It is thus that children are taught their A B C.

In the article which follows this in the present volume is a classification of all the Roots, and an account of their threefold functions; and having there provided a systematic description of the construction of the language, we may here proceed to consider what has been done to elucidate and display its contents, during the eventful first half of the present century. The dictionary next in importance to Dr. Morrison's, already noticed, is that of Dr. Medhurst, completed in 1848 . It came in opportunely for our more intimate intercourse with China, and being in octavo is more handy than its predecessor. The accurate learning of the author was a guarantee for its correctness, and it may be fairly designated as a most important and raluable work. The first two volumes are Chinese and English, and the two next English and Chinese. 
A very valuable and useful dictionary by Padre Gonsalves, of the College of St. José, in Macao, was printed by him some time before his death in 1844. From being unfortunately composed in Portugnese, the language least known in Europe, this work has suffered much in value, but all those who have been alle to avail themselres of its assistance have concurred in very highly praising it. The typography was what might have been expected from the backward state of the arts in a distant Portuguese colony; but the author's literary merits were acknowledged at Lisbon by his being enrolled as a member of the National Institute. This wortly man was driven by the colonial government of Macao, on account of his liberal tendencies, to take shelter on board the British merchant shipping in China, and he always spoke in grateful terms of the hospitality he there experienced, but complinined of being obliged to comply with the odious English custom of washing himself, and wearing a clean shirt every day.

Among works compiled in aid of Chinese literature was one printed by Dr. Morrison in 1817, and called a "View of China for Philological Purposes." This was a curious title for a quarto volume on geography, chronology, \&c., and the work was executed in a manner not less unusual, for the chronology is imerted, that is, beginning at the end, it ends at the begimning; as if one should compile a history of England, of which the narrative commenced with Qneen Victoria and ended with the Norman Conquest. Our ordinary notions of the succession of time are turned completely upside 
down, and it was snggested that, in consulting such a work, one should adopt a corresponding posture, and stand on one's herd.

I depart from the rule I had laid down, not to include in these notices the rejy latest aids to Chinese literature (thongl it is out of the first half-century by only four years), to mention the singular instance of a work which was published at the expense and with the care of a gentleman who had no professional call to study the language. The Hon. Henry Stanley edited and minted, in 1854, a most useful elementary work prepared long ago by a Frenchman in manuscript. It consists of 1500 of the most useful Chinese phrases, with a French and English translation, the latter substituted by the editor for the Latin in the manuseript, and as the sentences are of the most familiar kind they are an ample supply for common use. The characters are not printed, but taken by the new anastatic process from the writing of an Englishman with a common pen. It would have been better could types have been procured, but they are generally quite correct and easily decipherable; and this useful elementary work possesses the singularity of coming from one whose abstract and disinterested love of knowledge led lim to assist others in a department where he himself had no persomal interest whatever.

A rery useful rolume by Dr. Morrison was printed at Macao in 1816, called “Dialognes and Detached Sentences in the Chinese Langnage," a language which is rather to be acquired by examples than by rules of 
grammar. This work has become extremely scarce, from the greater portion of the impression being lost in the Aleeste frigate, which was wrecked homeward bound with Lord Amherst, in 1817.

A collection of two hundred Chinese moral maxims appeared in 1823, the original characters being inserted, with a verbal and a free translation; and this, perhaps, is the best mode of terching the grammatical structure of the language. It lias been pretty generally admitted that the proverbs and moral maxims of China possess considerable merit. The intrinsic goodness of some Chinese apophthegms has been extolled, among many others, by no less an anthority than Lord Brongliam himself. With reference to one of these maxims, his Lordship observes, "It is an admirable precept, to judlye ourseleses with the severity we appiy to others, and to judge others as indulymetly as ar do oursulves."

Our first object in England being naturally to increase our own acquaintance with the language, few attempts have as yet been mate to prepare works for the instruction of the Chincse. In 1810, howerer, Mr. Thom, who afterwards became H.M.'s first consul at the now port of Ningpo, edited a translation into Clinese of Fisop's and other fables. Among tho rest, this apologue from Horace:-

" Cerrus equam punát melior communilos herbis

Pellebat, lonec minor in certaninc longo,

Inploravit opes lominis, fronumue recepit;

Serd, postquan victor volens rliscess it ab hoste,

Non equitem durso, nrof fromm lepulit ore."

'Polit, I'hilosoltyy, wol, i., p. 172. 
Not the least useful part of Mr. Thom's work is a preface wherein much information is conveged as to the grammar and writing of the language. As might liave been expected, this book of fables, so new to the people of the Celestial Empire, took great hold of their imaginations. The mandarins, however, with the suspicion that always aceompanies guilt, saw in the falle of the wolf and the lamb, and others like it, a disagreealle resemliance to their own treatment of the people, and became hostile. Our first war was just commencing, persecution and proseription of the English were the chief study of the government, and Mr. Thom's book was condemned; but he succeeded in completing it at some risk to himself. Mr. Thom was my own official

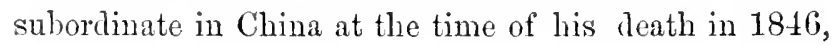
and $I$ have not forgotten the regret which the loss of so much industry and talent in the public service occasioned to all who knew him.

The principal early aids to the study of Chinese have now been noticed, and as the purport of this paper loes not extend beyond the first in point of date, it becomes superfluous to enumerate the later and better known results of a more extended range of inquiry among a much greater number of Sinologues. These are fully detailed in Professor Summers' preface to his " Handbook of the Chinese Language," printed at Oxford in 1862 ; the first work of the kind ever published at home, and in itself one of the most useful to students.

Our successful wars have entirely removed the barriers with which the native government formerly so long 
opposed all progress; md the growing exigencies of the Queen's service have given rise to many very able Sinologues, among whom the names of the late R. Morrison (son of the doctor), of Meadows, Medhurst, Wade, Parker, Lay, and Summers, figure conspicuonsly. Professor Summers, of King's College, London, has printed, as already noticed, a most useful handbook for beginners, containing a free use of the original character. He has also commenced a periodical called "The Chinese and Japanese Repository," which promises to supply the loss of the former "Chinese Repository," a valuable work, that will be noticed at the end of this paper.

China and Japan must now be treated in very near connection. Sir Rutherford Alcock observes that Japanese pictures have generally their titles attached in Chinese, and that to learn Japanese it is expedient, if not necessary, to commence with its prototype as the fomdation. In Sir Rutherford's work I can often read the Japanese titles to the illustrations. The silver coin, called itzelu, is distinctly stamped with four Chinese characters.

Le premier pas qui coute has long been surmounted, and it is perhaps desirable to place on record the difficulties and obstacles which besct the paths of the first explorers. In proof of the discouragement which opposed the acquisition of the language in the earliest times, we need only advert to the case of Mr. Flint, who, with the very slight and imperfect knowledge that conld be acpuired towards the end of the last entury, was long imprisoned by the Chinese Covernment, spereifically on account of that linowherge, and the lewitimate 
uses to which he entearoured to apply it. Our three wars have chamged all this. A large population in one of on nevest hat most flomrishing eolonies, Hongkong, necessitates the daily use of Chinese. We have a mint there stamping coins with the Queen's head, and Chinese characters on the olverse; as well as postage stamps so mirlied, which convey letters constwise to Peling, to the far extension of Sir Rowland Hill's fame.

Adverting next to the earlier translations from Chinese literature, we may class them roughly under these two heads:--I. Classical and historieal, including their sacred loooks. II. Belles-lettres, or drama, poetry, romances and norels. Travels out of China are of course few, and the little science they possess has not attracted much notice. Their industrious arts, on the other haud, might probably be investigated with considerable profit, now that we have such free access to the interior.

The "Four Boolss" of Confucius, and the "Fire King," or canonical works, constitute, from the unirersal reverence paid to the great national teacher, a species of sacred writings; and they have, for this reason, rather than their intrinsic merits, met with considerable notice in England and on the Continent. The earlier Jesuits at Peling had naturally turned their attention to these works, and Latin versions of the "Four Books" were sent to Europe, but remained generally unknown, except to the learned who could read them.

Confucius certainly influenced the opinions and destinies of a larger portion of mankiud than any other 
human teacher. Nor is he now a mere nominis umbra, but substantially represented by lineal descendants in his native province-Shantung. No other family might presume to adopt, under pain of death, the sacred patronymic of Koong, the first syllable of Koong-footse, or Confucius. The "descendants of the most holy teacher of antiquity," as they call him, have certain privileges, which the jealous goverument has taken care should (with his name) be exclusively monopolized. A lineal and undispouted descent of more than 2200 year's may certainly be claimed as the oldest in the world; and it happened to myself to come into a sort of official collision with one of them when I was Her Majesty's representative in China. The treasurer of Canton, for the time being, was one of the sacred and privileged fumily of Fomg, and I have preserved the envelope of his dispateh, bearing the much revered monosyllable.

The Lim-y", or "Conversations" of Confucius, which I have in another place ventured to call the Chinese Boswell, is somewhat like the record of our English sage, as transmitted by his humble armirer. The Ta-leco, or "Study for Grown Persons," commeneing with the government of one's self, deduees therefrom the government of a family, and thence extends the principle to the grovernment of a state, and of the whole empire-which in Chinese estimate once meant the whole world, until we first disilunsed them of the error. The 'Th-he'o properly stands at the head of the "Four Isooks," and the next to it in ordinary sequence 
is Choon!-yoong, the infillible medium or juste milieu,

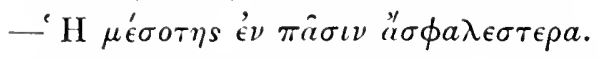

The last of the "Four Buoks" is Meng-tse, the work of Mencius, the most eminent of the disciples of Confucius, and contains maxims of government and political cconomy much in adrance of that early age, and fur more in keeping with our modern notions than eren the sayings of Confucius. I have in another place remarked some just olservations of Mencius on the division of labour, and on the necessity for distinctions of social rank. "Those who labour with their minds (he says) rule; those who labour with their bodies are ruled." The "Four Books" have during the first half of this century been more than once edited, in both English and French. The Titheo, or "School of Adults," was published so long ago as 1814, by Dr. Marshman, of Serampore, and is rendered more useful by the presence of the original text. The whole of the "Four Books" were published in English by Dr. Collic of Malacea in 1828. A more complete and elaborate edition than ever yet appeared is now in progress by Dr. Legge at Hongkong, two volumes only out of seren being completed.

With the "Four Books" come the Woo-ling or "Five Canonical Works," Confucius having been the author or compiler of all of them. For a detailed account of these I must refer to my work on China. The Ire-king, or "Book of Changes in Nature," having long ago been translated into Latin by Père Regis, was edited by Molll, and published at Stuttgard in 1834. Mohl had before edited an oller Latin translation of the Shi-king, or 
"Book of Odes" in 1830. De Guignes had, as long ago as 1770 , published his French edition of the Shooling, or "Historical Classic," and an English edition was printed by Dr. Medhurst, at Shanghae, in 1846, having the advantage of being coupled with the original text. The Chun-tsieu, a history of his own times by Confucius, has, I belicve, never yet been wholly translated into a European language; and the Le-ke, or "Book of Rites and Ceremonies," was rendered into French, accompanied with the text, by the late M. Callery.

Three smaller and more modern works are associater with the alove in the business of education, and in fact form its threshold. These are, 1. The Sin-tseling, or "Trimetrical Classic," as it has been called since I adopted that name for it in a treatise on Chinese poetry and versification. 2. The I'sien-tse un, or "Thousand Character Essay," and, 3. The Seco-heo, or "Youthful Study." These were all three translaterl by Dr. Bridgman and others. The first consists of the rudiments of linowledge in rhyming lines of three words each, calculated to help the momory. 'The second is an ingenious composition of one thousand different characters, forming sense together, and said to have blanched at onee, from the difficulty of the task, the head of the composer. These lave been lately printed in Paris by Professor Stanislas Julien, with translations in Latin and French. The third is, as its name imports, a rudimentary book for beginners.

All the foregoing works have of course less attration for Europeans than literature of a lighter and more 
popular himl: lut as the more considerable ones constitute the hasis of Chinese morals and polities, it would b. impessible to exelute them in a compenelious survey, or to deny them the first platee in it. Their general pinciples ane inculeated in the ". Sacred Instructions" of the Emperor to the people, alrealy mentioned as having heen trinsiated by the late Dr. Wilne from the original. There is no better book for learning and compariug the two styles of Chinese composition. The work comints of a text in the higher literary style, and a commentary in a more diffuse and popular pluraseology, ealculated for the masses. It is used as a lind of strmon for the people. On the 1st and 1,jth of every moon, one of the sixteen sections, under its proper text, is publicly recited by the proner of cicer ; but this Inay casily be supposed to have become a mere trite formality, which it really is.

One of the most rolmminons Chinese Histories, Thum-lien-linum-mo. was translated as long ago as 1770 by the Jestit Mailla at Peling, and printed at Paris in twelre quarto rolumes; but the profit of such a work was harly commensurate with the labour, and thominh in the course of so many years a good deal of reference has been mate to it, the work remains little known except to Sinolognes. The Sun-likrordie, which is rither a historical norel than a history, has not been much noticed. An untranslated Latin version. in the possession of the Royal Asiatic Suciety, has never been rendered into English. Thus it must ever be with the internal amnals of a nation hitherto segregated 
from the rest of the workd. The Butdhist religion having a commection with India, its history has excited more attention. M. Abel Rémusat translated the Fó kiliry-ky, or "Accomnt of the Buchllist Comntries," and the work was published in 1836, after his death. It is one of the most interesting notices of the country and the inhabitants of Easteru Asia extant, rendered especially enrious as the production of a travelled Chinese. Something analogons on this seore is the narrative of the Chinese Embassy to the Khan of the Tonrgoatl Tartars, translated by Sir George Stamiton, and pulrlished in 1821. An embassy despatehed by the Chinese gorermment through Russian Tartary, was a rare ocenrrence, and the narative loses nothing in interest from the way in which the ambassador himself hals recorded it. M. Stanishas Jutien in 1842 translated the Silcreal Jook of the Taou sect, or "Rationalists," called T'monter-line, or the "Seripture of the Way and of Virtue," by lan-tar, their tomeder. Whe introduction by the transliator does man to illustrate the tencts of this obsene sect. M. Julien hats since transtated a rery

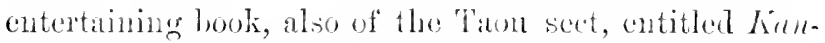
ging peren, or the " Jook of Rewards and P'mishments," by Tier sherel, or the "enceatly exilted" anthor of

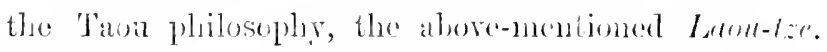
It is formded on the popular notion that every ated conormitted by a man during his life lots its rewath ol punshlunent, either in his own person or these of his

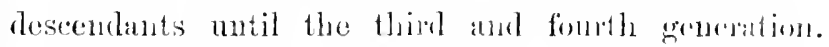
This might seem to exchule the notion of a finture 
state, hut there do ocasionally oecur the denmeiations of al hell for the wicked.

The most firomalble reception has perhaps been given to the lighter literature of Clina, or its belles lettres, comprising the Irama, Poetry, and Romances or Novels. The first specimen of their drama was given by Prémare, a Jesuit at Peling, already mentioned as anthor of the "Notitin Lineme Sinice." The "Orphan of Chaou" excited enongh notice in Europe to lecome the groundwork of Toltaire's "Orphelin de la Chine." The second specimen, in order of date, was my translattion of "The Heir in Old Age," in 1817. This play ilinstrates the importance which the Chinese attach to having a son to worship at the tombs of his family. A childless old man takes a second wife (or handmaid), with this object, and the jealousies and intrigues which arise on the birth of an heir make up the plot of the piece, at the same time that they display the domestic troubles which often naturally result from this oriental practice of having more than one partner, eren in the subordinate position of the inferior wife. This specimen of the Clinese stage had the adrantage of being edited, during my absence from England, by the late Sir John Barrow, of the Admiralty.

Six or eight translations of plays by different hands have since followed, and all have appeared in both French and English. The "Chalk Circle" was the version of M. Stanislas Julien, handsomely printed by the Oriental Translation Fund, as was also a second drama, called "The Sorrows of Han." The story of 
the "Chalk Circle" is virtually the same as the celebrated judgment of Solomon. Two women lay claim to a child, and the judge declares it must liclong to whichever shall succeed in dragging it out of the chalk circle, but awards it at last to her who, from tendemess and fear of injuring the child, fails to do so. M. Bazin translated four or five other specimens of the Chinese stage. Nearly all the above were selected from the Inen-jin-pue-choong, or " Hundred Plays of the Yuen," or Mongol dynasty. These in many respects resemble the European drama, and are mostly divided into five acts, or "breaks," as they call them.

In one of M. Bazin's translated plays a seene of genuine humour occurs in the person of a miser, which, as far as it goes, may fairly be comparred with the "Avare" of Molière.

One might not be prepared to find that the poetry of such a language as that in question possessed, in common with others so differently constituted, the properties of accent, metrical numbers, a cesural pause in the longer verses, and terminal rhymes, and was, moreorer, distingnished by what Bishop Lowth has elaborately treated in reference to Hebrew poetry, under the name of premellelism. Complets are thus distinguished, either by equivalence or antithesis of sense, or by an exact correspondence in verbal constrnction. This constitutes the merit of those ornamental lallels with which the Chinese decorate their honses ; for their characters adnit of an extent and variety of calligraphy to which onr few formal letters must of necessity be stramgers, 


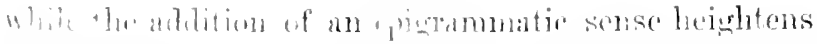

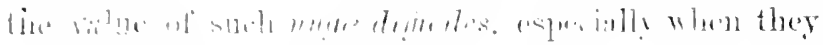

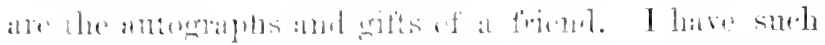

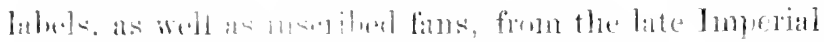

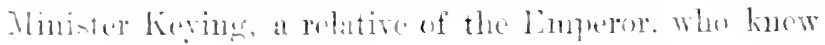

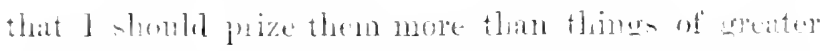
intrinsic vilue. The Royal Asiatic Society diel me the lromone, in 1829, to print in their quarto Transactions ${ }^{1}$ a treatise in which I endcaroured to exhanst the subject of the construction and literary character of chinese poetry, and in the course of more than thirty years I have not found that I conld add very much to the information therein contained.

There is ratler a favomalble specimen of poetry, with the original character added, in the eighth rolnme of the "Chinese Ropository," p. 195. The subject of it is " Gathering Tca-leares among the Hills" in spring time, and the yomg girl who is supposed to sing the ballat describes the sconery, the weather, her own dress, her feelings, …, in the most natural and therefore pleasing mamer.

It has been already observed that the poetry in question possesses the qualities of accent, measured numbers, and terminal rhymes, in common with of her languages so difierently constituted, and it is still more remarkable that they practise the somewhat refined amosement of what the French call bouts-rimes. A drawing on silk, in the Chinese style, was sent to me

1 Tol. ii., p. 398. 
by one of the captors of Peking, and I found on examination that it was a case of this description. The Emperor had given two or three of his faromite officers the Iuru yun, or "Original Rhymes," which they were to fill in on a prescribed subject. This subject was the Heang-Shen, or "Fragrant. Hills," leing the immer and more sechuded portion of the park of the Summer Palace (which was burned down by our forces in 1860, in just, though bloodless, retribution for the murder of our countrymen), and, as it turned out, the birthplace of the reigning Emperor. The following account was given of it $1, y$ an cyewitness: ${ }^{1}$-_ " Another collection of buildings, embosomed in trees, and girt round by a serpentine wall, which ran uj the face of the hills, took a turn orer their tops, and again descended to the plain. This was called Irang-shene, or the 'Fragrant Hills,' and formed the fourth or innermost parts of the Emperor. The arrangement of these HeangShan pleasure gromds was even more complete than that of the three before visited. The flights of stome steps leading from palace to palace, with the rumal summer-houses, shady bowers, and delightful terraces, mate the spot "fuite mique, and of a perfect loveliness all its own." A riew of this place, as alowe described, forms the sulject of the drawing on silk, which is stamped in red with the Emperor's private seal.

We conce, lastly, to the lighter literature of romancess and novels, on the suliject of which I have always 


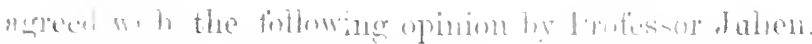

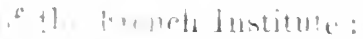

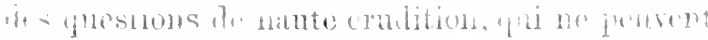

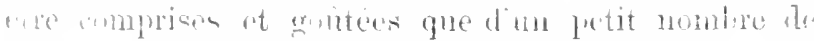

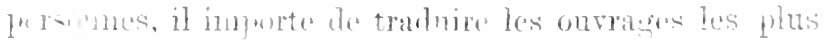

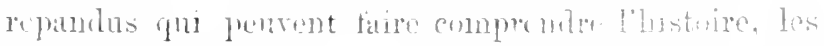
religions, les mours, les usages, et la littérature des Chinois." With similar sentiments, the late Professor Remusat unclertook the translation of a novel, which Ile styled "Les Denx Consines," though that is not the precise meaning of its Chinese title. The whole story turns rery much upon verse-making and bouts-rimés, and is not a bad illustration of their notions of poetry as an accomplishment, female as well as male. The mere ontline of a rather celebrated romance, called Inom-liew-chnen, the history of the "Fortunate or Well-assorted Cnion," had been published by Bishop Percy, from a MS. sent from Canton, being translated afterwards into French, and published at Lyons in 1766. On examining the original work, and observing how little of its merits were apparent in this brief and imperfect abstract, abounding as it did in the most palpable mistakes, a rersion of the whole was undertaken, and printed by the Oriental Translation Committee in 1829, being published in two volumes. Though a most faithful description of Chinese mamners in the upper and more enlightened classes, there is nothing in the plot to shock European sentiment; such, for instance, as the hero espousing two wives, in the ancient oriental, and modern occidental fashion among 
the Mormons. M. Rémusat olsserves, in his preface (written in 1826) to the "Deux Consines," "Un homme qui aime deux femmes à la fois est une sorte de monstre qu'on n'a jamais vu qu'au fond de l'Asie, et dont l'espèce est tout-a-fait ineonnue dans l'Oceident." He was little aware how soon erents in North America would render his observations antiquated and inapplicable to the present time.

Mr. Wade, our Secretary of Legation at Peking, and a first-rate Chinese scholar, has taken advantage of his residence at the Chinese capital to print a larger and more correct edition of the original Heto-liew-chuen than ever has been seen before. His object is, that, for the use of students, it should accompany the translation, in two volumes, made thirty-five years ago; and the recognition, in such a quarter, of the general aceuracy of the translation, is of comrse a souree of satisfaction. Mr. Wade has opened an easy way to the Peking dialect by lis "Book of Experiments," one of the most useful elementary works yet published.

"Blanche et Bleue, on les Deux Couleuvres Fées," translated by M. Julien, is a curious specimen of a fairy tale, wherein two young females are transformed into scrpents, and, after a long penance in that condition, are compensated at length for their sufferings by being restored to their original state. 'This is a tale of the Tuou sect, or Rationalists. M. Pavie has translated seven tales, illustrative of the popular Chinese superstitions, muler the title of "Choix de Contes et Nourclles." Mr. Pobert Thom, during the same state of persecution 
muler which he publishen his ('hinese version of Esop's Fables, contrived to print, at Canton, during the tronlules of 1s:39, a translation from a short tale, containing the adventures of a talented heroine. He then spoke ferelingly of the degraded condition of Europeans in Chinil: but, in three years from that time, was appointed Her Hajesty's Consul at one of the new ports, unter a state of things bronght abont by our successful witr, which completely revolutionized the old system of exchusireness and restraint.

Mr. Thom's Chinese rersion of Esop's Falles had hecn chiefly effected by the aid of an educated native, and this translition from English into the native language was, not long after, followed by a native Chinese named Tsin-shen, translating from his own language into English a work called the "Travels of the Enıperor Chingteh in Keang-nan." The story relates to the commencenent of the Ming, or Chinese dynasty, which succeeded the Mongols. To any one who lras read the San-7inro-che, or "History of the Three Kingdoms," this will appear to be an initation, on a reducer scale. The conclusion of the tale abounds in descriptions of those strange magical practices to be found in the oller work, nor can anthing more extraragant exist in the wildest Arabian fiction. The translation was revised and published by Dr. Legge of Malacea in 1843.

In conchuding this summary riew of the principal aids to the Chinese language, and the most considerable translated works which have marked its rise and 
early progress, not only in this country but in France, it becomes impossible to pass in silence a most valuable and meritorious periodical, the "Chinese Repository," which occupied the twenty years between 1831 and 1850. Published at Canton in monthly numbers, by Dr. Bridgman, an American, this became the common receptacle for contributions from Chinese scholars of all countries; while the font of Chinese types which had been made for Morrison's Dictionary rendered it easy to print a great deal in the original character. The fate of this valuable work, however, was to a considerable extent that of the Sibyl's books. One of those frequent fires which desolated Canton caused the destruction of the greater portion of the impression, and the value of the remaining parts has become, of course, enhanced in proportion. A very imperfect copy, minus sereral volumes, has been marker in a bookseller's catalogue at $\mathfrak{l} 20$, but a few individluals, including myself, are fortunate enougl to lold perfect and entire copies, the value of which, in this particular branch of literature, is not easily appreciable.

Note.-With reference to the observations at lage $6 ; 3$, on the existing dexcendants of Confueius, the following notice by (xiblon has been found in lis Autoliography,

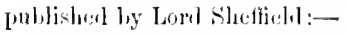

"The family of confucius is in my opinion the nost illustrioms in the world. After a latinful iseent of eight or ten centuries, our barons and princes of Europe are lost in the darkness of the millde ages; but in the vast equality of the empire of Clina the posterity of Confucius have maintained, above two thomsand two humbed years, their peaceful homours and jerpelual succession." -Misecllaueou.s Worlis, vul. i., I1, 4. 


\section{THE ROOTS OF THE LANGULGE,}

(From the Procectings of the Philological Soeiety.)

IT is pretty generally known that, under 214 Roots or radirnl and original characters, the whole of the Chinese language is arranged in the dictionaries. It is not easy to orerrate the importance of these roots, when we consider that they enter into the composition, and influence the meaning of every word in that language.

The late MI. Abel Rémusat of Paris remarked, that in addition to their other uses (which will be presently noticed) these roots singly represent or express the leading oljects or ideas that men have occasion to communicate in the infancy of their knowledge ; comprising within their number the heads of genera and classes in nature, and thus affording the elements and means of a philosophic system of arrangement. A fortunate instinct led the framers of the language, instead of 
forming characters altogether new and arbitrary, to express new objects or ideas by the ingenious combination of those elementary symbols which they already possessed. Thus among the roots we find horse, dog, metal, \&e., and the addition of some other significant symbol, expressive of some peeuliar property or characteristic, serves to designate the different species comprised under the different genera, as horse-ass, lon'ssmule; dog-uolf, dog-fox; metal-iron, metal-sitzer; the elementary or generic words, horse, dog, metal, being those under which the componnds are ranged in the dictionary.

The obvious analogy which this system (howerer imperfect in its details) bears to the principle of the Limnxan nomenclature led M. Rémusat to clissify that portion of the 214 roots, consisting of only about thirty in all, which had reference to genera in the animal, regetable, and mineral kingdoms. Whatever might be the results in a scientific point of view, and in regard to natural history only, this sort of classification appeared to me to possess considerable interest and utility on the seore of general philology, and with a view to the partienlar study of the language in question. I have accordingly attempted to perform for the whole 214 roots what M. Rémusat did for that smill portion to which he confined his attention. In so doingr $I$ lave nearly retained M. Rémusat's classification under the heads of the three natural kingroms, but extrinded the number to thirty-three roots; and the following are, in the first place, the general heads moder which 
the whole 214 roots secun most realily to arrange themsolves:-

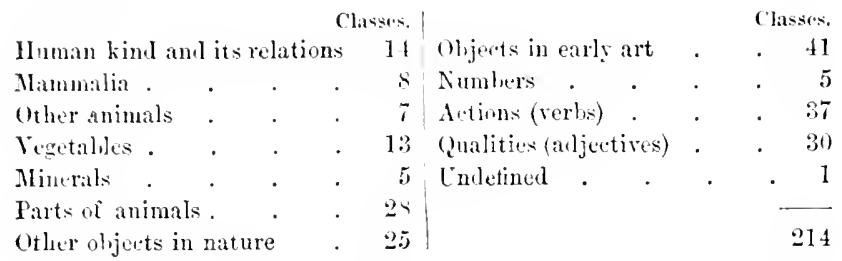

Whaterer additional interest and importance on more intimate relations may now attach to the language of China on the score of utility alone, its very singular structure entitles it to attention as a part of the listory of the homaln mind, and of philology in genexal. I hate accordingly been tempted to extend this cxaminafion from the mere classification of the roots to a computation of the proportion in which each separate root enters into the construction of the whole langruage. The dietionary which was selected for this purpose contained about 11,690 worts, the really usceful and practical part of the language. The following tables exhilit each root, arranged moler its orm particular ciass. and mumbered on the left (for facility of reference) according to its numerical order in all the dictionaries, by which it may be imnceliatcly found in the table of Morrison's Dictionary. The colmun of figures on the right shows the total number of compound words to be found under each root:-

Hesure hind and its Relotions.

No.

y. Man

11. (Another form)

23. Scholar, sage
Compinunis. 478 21

10
Nammative.

No.

Compounds.

3. Woman

. 243

39. Son

31

44. Corite. 
No.

45. Workman

49. Self

83. Family, kindred

8.5. Father .

131. Minister, servant .

132. Seli

155. Boly, person

194. Ghost, spirit

93. $0 \mathrm{x}$

94. Dor

12:3. Shetp.

141. Ticer

152. Hog

18\%. Hurse

1:4. Decr.

20s. Rat or monse

$$
\text { (Mher Inincels. }
$$

142. Insert .

2.5

15:3. Reprile

172. Hirl

195. Jish

1!ni. Latece lirals

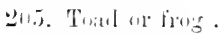

218. Turtuis:

\section{legrtaldes.}

4.). Pinl ar sprout

(i.). Jirum h

75. frees, work

97. Melun tribe

115. (irain in hask

11\%. b:tuluen

11:1. Rives

110) (irase, herbs.

151. Jic:un

179. Onion, leek .

]!). Whrott.

sii). Ilturis.

20). Millet

Mincerels.

:3. Eitrth, soil .

!);. Jales, intem

11:. Stone, ruek
Compounds. No.

Compoumts.

167. Hetal. . . . 207

197. Silt . . . . 4

Paits, ice., of Animals.

30. Nouth .

437

58. Head of a hog . . 8

59. Loner hitir or feathers . 11

61 . Heart . . . . 40\%

64. Hanl. . . . 492

29. (Another form) . . 201

8\%. Fur of animals . . 30

84. Breath, vapour . . 1

s7. Nail, claw. . . 7

92. Teeth. . . 3

114. Disease . . . 192

1117 . Skin . . . 13

1119. Lre . . . . 1 15

124. Wing feitlers . . 43

12. Haril of the fiace. . S

12̧. Ear . . . . 36

130. Flesh . . . . 220

1:5. Tongue . . . I1)

143. Lilond. . . . I11

14. Ilorn . . . . : : . 1

Tit. Fust . . . 155

17it. bitee. . . !

1>1. Ileat. . . . st

15.\%. Hewerle rief. . . . 2

14s. lime. . . . 47

1!3). Mait of the lieal . . 1:3

20.5. Nise. . . !

211. 'leeth. . . 8 87

other olligets in Nieteres.

8. Point, lut . . . 5

1:3. Wilderness, desert - 1

15. Iriele. . . li;

17. lit, recolitele . . it

2.2. buresitury . . . 1!

23. llilims-plare . . 8

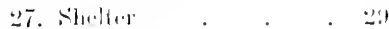

sti, Evoniug, twiliglit. . 11

li. llill, momntain . . 1f:

47. Wathreantses, stream . y 


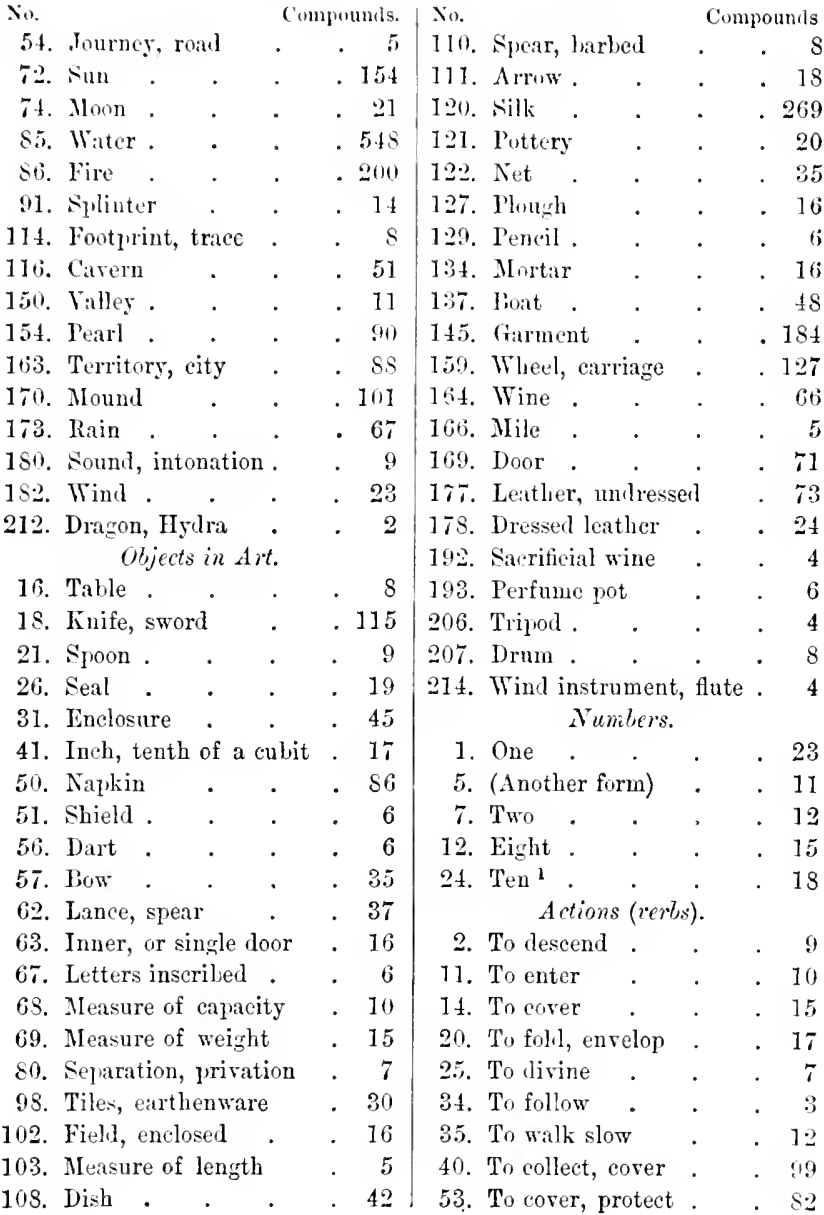

1 All the other numerals, to nine inclusive, are deriverl from these, with the exception of Four, and that was also in its original form.
The Chinese numerals 1, 2, 3, and 10, are the Roman numerals I., II., III., and X., turned the other way. 
No.

55. To join hands

Compounds. No.

Compoumis.

60. To pace, walk

19. Strong .

$6 t^{\circ}$

25. Crooked, perverse. . 7

66. To touch lightly . . 70

73. To say, speak . . 14

37. Great . • . . 49

76. To owe, want

42. Little. . . . 11

77. To stop, cease

43. Distorted

11

5.2. Slender, young . . 4

7\%. To kill

70. Square.

29

S1: To compare. . . 7

S9. To imitate. . . 4

100. To produce, give life . 6

101. To use. . . . 4

165. To stride, issue forth . 3

113. To arlmonish, by omen . 97

117. To erect, establish . 26

136. To (listurb, oppose . 4

144. To do, to act . . 15

146. To oversballow . . ti

147. To see.

71. Defective, wanting . 3

78. Bad, rotten. . 58

90. Inclining . . . 7

95. Dark-coloured . . 3

99. Sweet. . . 10

1016. White. . . . 29

125. Aged . . . . 8

133. Extreme, reaching to . 5

138. Disobedient. . . 3

139. Coloured . . . 4

155. Red. . . . 10

149. To speak, express . . 373

160. Bitter. . . . 11

15\%. To walk . . . 45

161. To mark time . . 4

162. To walk swiftly . . 145

165. To separate, divide . 4

183. To $\mathrm{H}_{y}$. . . . . 3

181. To eit. . . . 9t

191. To fight . . . 10

204. To embroider . . 3

Qualities (Arjectices).

4. Inclined, biassed . . 16

6. Hooked

165. Long, extendel . . 2

171. Reaching to. . . 3

17. Azme, blue. . . 8

I75. False . . . . 10

186. Fragrant . . . 10

1s9. High . . . . 4

201. Yellow . . . 8

2113. Black . . . . 20

210. Even, arjusted . . 5

tridrined.

8. Useal only in composition 10

Some of the results of the preceding tables are curions, especially the disproportionate importance of different roots in the general construction of the lin1guage. It appears that, of the total number of 11,600 words, no less than 8,200 are comprised under only $3: 3$ roots, viz. :-

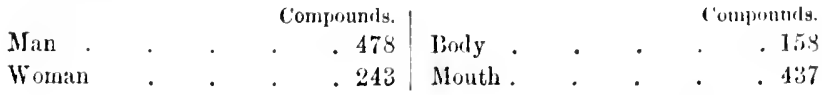




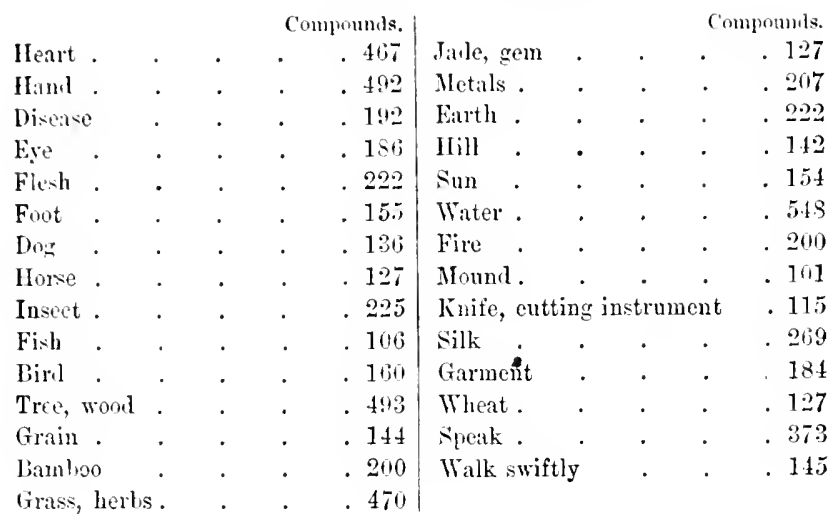

An extended analysis shows that the small proportion of only seren roots comprehend under them no less than 3,385 words.

\begin{tabular}{|c|c|c|c|c|c|}
\hline & & Compounds. & & & Compounds. \\
\hline $\operatorname{Man}$ & . &.$\quad .478$ & Tree, wood . & . & . .493 \\
\hline Mouth & . & . 437 & Grass, herbs. & . & . 470 \\
\hline Heart. & . & . 467 & Water. & . & .548 \\
\hline Hand & . & . 492 & & & \\
\hline
\end{tabular}

It is apparent that the bulk of these 214 roots, or primitive words, consists of nouns substantice, the names of the principal objects in nature or early art; and their generic character seems to corroborate the opinion of Dr. Adam Smith, in an essay concerning the first formation of languages, appended to his work on the Theory of Moral Sentiments. He observes that the assigning particular names to denote particular objects, that is, the institution of nouns sulstantire, would probably be one of the first steps towards the formation of language. The objects most familiar to 
two aborigines would have particular names given to them, as a cure, a tree, a river. Where they met with other oljects, altogether similar to these, they would give the same names rather than invent new ones; and thus these words, which were originally the proper mames of individuals, would each of them become the common name of a multitude or class. It is this application of the nome of an individual to a great multitude of similar objects that seems to bave given occasion to the carly formation of those comprehensive classes which we call genera, and which are admirably represented by the Chinese roots. With the progress of knowledge, the necessity for partieularizing and distinguishing led to the construction of those thousands of compound words or characters which the Chinese ingenionsly formed by the combinations of the simple roots, and which are arranged under the roots in their dictionaries as species under genere. We may adt, that the same punciple seems to have been finally extended by them, from sensible oljects to abstract ideas -from the concrete to the alsstract.

How superior such a rational, and often philosophieal, combination of the elementary symbols, to the more rude and inartificial scheme of continuing to form new and additional chatracters, altogether independent and arbitrary, and thus lamelhing on a sea of multitulinous perplexity, to which scarcely any luman intellect conld ever have been equal. Snch, however, has lowe tho notion attached to the Chinese by many minformed persons, who have in this mamner most armonomsly 
enhaneed the supposed amount of libour and power of memory repuired for the mastery of the limgnage, at the same time that they have innored the extreme ingennity ly which an ileographic system has been rendered comparatirely simple and easy of acquirement. Comparative simplicity, howerer. and faleility of acquirement are not the only merits of the system. These will be best explained by consideng in sucession the three distinct uses which the roots serve. First, as supplying, in their simple and nucombined state, the place of an alphabet for lexicographic arrangement and reference. Secondly, as indicating, when combined, the derivation and meaning of compound words. Thirdly, as already explained, constituting the heads of a sort of Limmean classification.

I. An alphabet the Chinese roots certainly are not, for they are not plonetic, but ileographic stmbols; but they have heen made to serre all the purposes of an alphabet in dictionaries. The arrangement and succession of the letters in onr European alphabets would seem to be purely arbitrary. There is no reason in the nature of things why $\mathrm{Z}$ might not have been the first letter in our alphalect, and A the last; or why, in the Greek, Omega shonld not have come in time to imply "the legiming," and Alpha " the end." But a good and sufficient reason exists for the arrangement of the Chinese roots. They snceed in order strictly according to the number of strokes of which each is composed. The limited number of letters in our Western alphabets renders their arbitrary arrangement of little importance ; 
for the abecendaire, as the French term it, is easily eommitted to memory; but the roots in question being rather more than eight times as numerous as our phonetic elements, this disadrantage has been greatly mitigated by the numerical classification; and those idleographie elements are thus turned to in their dictionaries and found with equal facility and despatch by the above simple method. The obrious advantage of this numerical srstem has been extended in their dictionaries from the roots themselves to the eompounds, which are arranged under them. Similar ends suggest analogous means. As the Chinese extend the arrangement by the number of strokes from the roots themselves to the compounds ranged under them, so we of the West extend the alphabetic arrangement from the letters themselves to the words ranged under thiem, according to the alphubetic suecession of the letters in each word. In turning to the Chinese root you find the compound under it in its right place, indicated as this is by the number of distinct strokes which compose it, independent of the root. Thus in looking at the charaeter or word which signifies copper, before secking it in the dictionary, the searcher sees at a glance it is the root line, or metal, with the addition of another character of six strokes, and thus easily discovers the word in its proper place, defined as the particular article "copler," under the general torm "metal."

II. Our alphabetical spelling affords no indication of the meming of a worel to him who has nexere met with it before. The first letter, M, or the first syllilble, Mim, 
would he no clue to the import of the word Mimdate. But when a Chinese sees that $人$ jhin, "a man," is the root of a character, he linows the word has a reference to the human race in some one or other of its relations ; and this at once assists his conception of the meaning, and helps him to remember it. The writing of his comntry convers at once its impression throngh the eye : erery character is a visille representation, however unlike, of the thing meant, and produces a more vivid and listing eflect on the mind than by the less lirect phonetic medium; for-

\section{"Serniùs irritant animos demissa per aurem, Quam quie sunt oculis subjecta fidelibus."}

For this reason the 214 Chinese roots are remembered with little difficulty ; but an alphabet of $21 \pm$ elements of mere sound (if this were necessary, or eren possible) would be a serious affin. A Chinese has at first no conception of the use of our letters. He sees on the page a perpetnal repetition (to use a school-boy phrase), of a few pothooks and hangers. $\mathrm{He}$ is astonished to hear that we have only about twenty-six characters in all; and if he proceeds to learn them his previous literary notions are completely upset. To him the grand difficulty is the trying to acquire mere elements of sound insteal of symbols of ideas. In lis own language he had learnt that the root $甘$, jih, meant the sun, and the root 月, yue, the moon, and as these 
bore some real or fancich resemblance to the oljects he easily remembered them. When, again, he learned that the combination of these two elements signified $B$ 月, ming, bright, enlightened, the relation was obvious, and he did not forget it. This in some measure compensates for the disadvantage of so many as 214 ideograplic symbols, in lieu of only 26 of a phonetic description. The present is not intended as a piece of specinl pleading to prove that their system is letter than ours, which it certainly is not, nor nearly as good; but to show that the case of the Chinese is not so bad as has been supposed, or guessed at.

III. The third and most interesting office of the roots is in serving not only as the elements of all compound words, but as the generic heads for their speeific classification. The associations that have governed the formation of compounds are often obvious, and they occasionally afford curious lessons in psychology, or the operations of the hmman mind. The root "man," combined with "one," simply denotes alone, deserted; with "thousand," a chiliarch, the chicf of a thousand; with "hundren," a conturion; with "white," an cldr" or senior"; with "ficld," a husbandman; with "village," a rustir, untutorerl; with "emperor," noble, clereted ; with "justice," righl, correct. 'The root T't, "great," comlined with hoong, "a low," forms the word $E e$ " "a harlarian," whiel once raised so murh troulle and discussion with the Chinese. On this point of etymology, however, we have turned the tahles 
on them, for they retain the how while we have adranced to the ritle, which latter article will in time call for the invention of a new term among them.

It maly be remarked that the root sin, "heart," enters into the composition of more worls than most of the others. With us, the heart is the seat of the affections or cmotions, but with them of the intellect also. Combined with hea, "downwards," it means literally "downhearted;" with tam, "a linife," the meaning is trom, "griered;" with sen!, "nature, birth," it implies sing, "natural disposition;" with $" w h$, "the ear," it forms che, "conscience, a sense of shame," thus presenting in a single word the itlea conveyed by our plurase "the whisperings of conscience."

With regard to the classification of the three lingdoms of nature, we find unter the root che, "hog," the compound scand, "an elephant," which, as one of the pachydermata, might be correct enough. Nany of the compounds, however, are rery incorrectly classed, and have not the remotest affinity with the root. Under new, "ox," is found, se, "rhinoceros." The wolf and fox are properly ranged under the root kenen, "dog," but so also is the ape, and, strange to say, the lion.

The regetable kingdom, with the exception of a very few instances-as rice and bamboo, which are themselves roots par excellence,-is arranged mainly under the roots, muh, "trees," and tsaou, "herbs," the former indicating not only all species of trees, but everything composed of, or haring a relation to, wood; the latter all herbaceous plants and regetable 
productions that are not ligneous. The cereal grains are, from their importance, arranged under a single root 秉, ho. From imparting their direct meaning to compounds, the roots proceed to convey a figurative signification. Thus, 禾, ho, "grain," in composition with 火. ho, "fire, or heat," means the autumn; 条, tung, "winter," is distinguished by the presence of ping, "icicle;" the meaning of 春, chun, "spring," is indicated by the "sun" appearing from below. If Anglo-Chinese dictionaries would always point out these relations between the composition of words and their import, not only would the meaning be elneidated, but the memory of the searcher at the same time greatly assisted. He las gencrally been left to do this for himself.

The mineral kingdom is classed principally under 土, too, "earth," and 金, liin, "metal," and these roots also compose the names of the implements or things having a relation to those materials. A philosophical Chinese chenist, in advance of his conntrymen, might arrange all alladine sulsstances, under the root too, "cartlı," and their metallic hases muler likn, " metal." But their nsual mode of designatingr any new foreign importation is ly adopting the name of something native, that hears a real or fincied rescmblinee to it, and adding the term "foreign." 
Tho poenline atrantages of this metium, such as they are, latre rembered it a miversal charatere not only anong the 300 millions of Chima, but in the lingtoms of .T:pan and Ammam, Corea and Tumghing; in fact ucarly half the hmman race. I proceeded in 1847 with two of Her Majesty's ships to 'Turom Bay, in Annam (where the French lave now by military pressure acquired rather an mprofitable colony), with the view of trying to conclude a commercial treaty, and there I found that witlout knowing a syllable of their spoken language I could correspond with the officers of goverument as completely as in China. With regard, also, to Japan, it is clear, from Sir Rutherford Alcock's work, that the pure Chinese character is very generally used and understood. Mr. Medhurst likewise states, "From my recent risit to Japan I have been much struck by the general and familiar use made by the Japanese of the Chinese witten language, in its own regular construction." It is no doubt the fons et origo of Japanese letters. 


\section{T.}

\section{THE DRAMA, NOYELS, AND ROMANCES.}

(From the Quarterly Recicu.)

The Chinese stand eminently distinguished from other Asiatic nations by their early possession, and extensive use, of the art of printing-of printing, too, in that particular shape, the stereotype, which is best calculated, by multiplying the copies and cheapening the price, to promote the circulation of every species of their litcrature. Hence they are, as might be expected, a rending people; a certain quantity of edueation is universat among even the lower classes-and among the higher, it is superfhous to insist on the great estimation in which letters must be held, under a system where learning forms the very threshold of the gate that conducts to fime, honours, and civil employment. Anichst the vast mass of printed books, which is the natural oflspring of such a state of things, the circle of their popular literature las the best claim to our atterntion; and there anpears no readier or moro ancealle mode of lecoming intimately acquainted with a peeple, from whom Europe can have so little to learn on the score of either moral or physical scienere, than by drawing laugely from the inexhaustible steres of their lighter liendere. The publication, hy that very active 
association, the Oriental Translation Fund, of the Chinese tragenly, which we are to analyse in this article, furmishes an oceasion of introducing some ohservations on the sulject-of throwing, we trust, some new lights upon it, and inresting it with additional interest.

The Chinese themselves make no technical distinctions letween tragrdy and comedy in their stage pieces; - the dialogne of which is composed in ordinary prose, while the principal performer now and then chants forth, in unison with music, a species of soug or vandeville, and the name of the tune or air is always inserted at the top of the passage to be sung.

A translator from their language seems, howerer, at liberty to apply those terms, according to the serious and dignified, or comic and familiar character of the composition which he selects. In choosing his own specimen from among so many, the translator of the Sorrows of Han, "was inflnenced by the consideration of its remarkable accordance with our own canons of criticism. The unity of action is complete, and the unities of time and place much less violated than they frequently are on the English stage. The grandeur and gravity of the sulject, the rank and dignity of the personages, the tragical catastrophe, and the strict award of poetical justice, might satisfy the most rigid admirer of Grecian rules. The translator has thought it necessary to adhere to the original, in distinguishing by name the first act, or proem, from the four which follow it; but the distinction is purely nominal, and the 
piece consists, to all intents and purposes, of five acts. It is remarkable that this peculiar division holds true with regard to a large number of the "Hundred Plays of Tuen"-from which the present drama is taken.

Love and war, too, very legitimate suljects of tragedy, constitute its whole action, and the langnage of the imperial lover is frequently passionate to a degree one is not prepared to expect in such a country as China. The nature of its civil institutions, and the degraded state of the female sex, might generally be pronounced unfarourable to the more elevalted strains of the erotic muse. The bulk of the people, it might be thought, are too much straitened for the bane means of subsistence, throngh the pressing demands of an excessive population, to admit of their singing after the most approved manner of idle shepherds and shepherdesses; and the well-educated clatss, which comprehends almost all the higher ranks, or those in the employ of the gorermment, too proud and unfeeling to make love the theme of their compositions-which are doubtless chiefly confined to moral and speculative, or descriptive suljects. The drama in question, howerer, may teach us not to pronounce too dogmatically on such points ly reasonings is priori, lut to wait patiently for the fruts of actual research amt experience.

The moral of this play is evidently to cxpose the evil consegnences of luxnry, effiminaty, and supincuess in the sovereign-

"When love was all an easy monardi's care, Seldom at council, never in a war." 
The suljeet is strietly historical, and relates to that interesting period of the Chinese anmals when the declining strength of the government emboliened the Tartars in their agoressions, and gave rise to the temporising and impolitic system of propitiating those barharians ly alliances and tribute, which at last produeed the downfall of the empire and the estallishment of the Mongol dominion. The drama opens with the entrance of the Tartar Khan, reciting these rerses :-

"The autumnal gale blows willly through the grass, amilst our woollen tents,

Alul the moon of night, shining on the rule huts, hears the lament of the mournful pipe;

The countiess hosts, with their bended lows, oleer me as their leader ; Our tribes are the distinguished friends of the family of Han."

This formidable Scythian displays his friendship after a singular faslion, as we shall see presently. He ends a speech, which may be considered either as a soliloquy or as an address to the andience, thus:-

"We have mored to the south, and approached the border, claiming an alliance with the Imperial race. Yesterday, I despratched an enroy, with tributary presents, to demand a princess in marriage, but know nnt if the Emperor will ratify the engagement with the customary oaths. The fineness of the season has drawn away our chiefs on a hunting excursion, araidst the sandy steppes: may they meet with success! for we Tartars have no fields; our bows and arrows are our sole means of subsistence." [E.cit.]

The Clinese leare more to the imagination than we do ; for they neither contrive that the action should all proceed on one spot, as in the Greek tragedy, nor do they make use of shifting scenes. "You can nerer bring in a wall," says Snug, the joiner-so say the Chinese; and their contrivance, thongh not quite so 
absurd as those of the "Mechanicals" in Midsummer Night's Iream, are searcely more artificial.

The next personage that appear's is the minister of the emperor, and he at once displays his character by these four verses, with the recital of which he enters :-

"Let a man bave the heart of a kite, and the talons of an eagle;

Let him deceive his superiors, and oppress those below him;

Let him enlist flattery, insinuation, protligacy, and ararice on his side, And he will then find them a lasting assistance through life."

The falsehood of this bad morality, howerer, is ultimately proved in the fate of its author, who thus continues :-

"Iyy a bundred arts of specinus flattery and address, I have deceived the Emperor, mutil he places his chicf lelight in me alone. My words he listens to, and he follows my counsel. Within the grecinets of the palace, as without them, who is there hut hows betore me, who is there but trembles at my alproach! But olserve the chiel art which 1 have learned-it is this: to gersuade the emperor to keep aluof from his wise counsellore, and seek all his pleasures amilst the women of his palace. Thus it is that I strengthen my pwwer and greatuess; lut in the midst of my lucalnations, here cones the emperor."

(Entor the Emperor Yuente, attended by cunurhs and umon.)

"Emp. (Revites verses). - During the ten generations that have sucecederl our acruisition of empire,

My race has alone possessed the four hundred districts of the world : I

Long have the fronticrs been bound in trampuillity by the ties of mutuld oaths ;

And our pillow has been unisturbed by grief or anxicty."

The worthy minister and his sovereign angree that there is no lecter morle of improving these pipinger times of peace, than by arling to the mumbers of the imperial harem: the forrourte is appointed on the spot commissioner of selection, desired to scareh dilingently 
through the realm for all that is most beatiful of wominlind, between the ages of fifteen and twenty, and then furnish his master with portraits of each, as a means of fixing his choice. And so cnds the introductory act.

The minister proceeds on his commission, and does just what Falstaff did on his recruiting service"misuses the ling's press most damnally." The Knight, howerer, takes money for letting off the proper objects of his selection, and discharges those likely fellows, Bullcalf and Mouldy, while he marshals in his ranks the half-faced Shadow, the forceless Fechle, and the ragged Wart. Our emissary, on the contrary, was lribed to take, and not to reject. He met at length with a maiden of uncommon attractions :-

"The brightness of her charms was piercing as an arrow! She was perfectly beautiful; and doubtless unparalleled in the whole empire. But nnfortunately her father is a cultivator of the land, not possessed of much wealth. When I insisted on a hundred ounces of gold to secure her leing the chief olject of the imperial choice, they first pleaded their porerty; and then, relying on her extraordinary leauty, rejected my offers altogether. I therefore left them. (C'onsiders authile.)-But no! I have a better plan. (He linits his brous, and matures his seleme.) I will disfigure her portrait in such manner, that when it reaches the Emperor, it shall secure her being doomed to neglected sechusion. Thus I shall contrive to make her unhapy for life ${ }^{1}$-l lase is the man who delights not in rerenge!"”

We next see the lady herself, who appears soliloquizing amidst the shades of night :-

"My mother dreamed, on the day I was born, that the light of the moon shone ou her bosom, but was soon cast low to the earth. ${ }^{2}$ I was

1 Because, once admitted within the precincts of the palace, she could never return home.
2 Boding a short, but fatal dis. tinction to her offepring. 
just eigliteen sears of age when chosen as an inhabitant of the imperial palace : but the minister, Maousenshow, disappointed in the treasure whieh he demamled on my account, disficurer my portrait in such manner as to keep me out of the empreror"s presence, and now I live in neglected solitude. While at home, I learned a little music, and could play a few airs on the lute. Thus sorrowing in the stillness of mirlnisht, let me practise one of my songs to dispel ny griefs. (Begins to play on the lute.)

\section{(Enter Emperor, attended by a cumuch, carrying a light.)}

"Emp. - Since the beanties were selected to grace our palace, we have not yet discorered a worthy object on whom to fix our preference. Vexed and disaplointed, we have passed this day of leisure, roaming in search of her who may be destinel for our imperial choice. (IIetr's the lute.) Is not that some lady's hute!

"Attend.-It is; I hasten to arlvise her of your Majesty"s approach.

"Emp.-No, hold! Keeper of the yellow gate, discorer to what part of our palace that lady pertaius, and lid her approach our presente; but beware lest you alitum her.

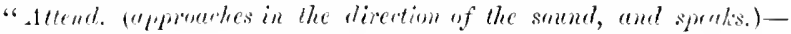
What lawly plays there? The esuperor comes; ajproach to meet him. (Lady adveluers.)

"Limp.- Keeper of the yellow gate, see that the light burns brightly within your ganze lanmp, and holl it nearer to us.

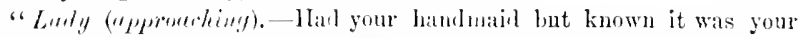
majesty, she would have been les tarly ; forgive, then, this delay.

"Emp.-Truly this is a very perfect bealuty! from what quarter come such superior charms ?"

The secret is now discovered, and the lady nakes known to his majesty the cruel perfidy of the minister.

"Eimp.-Keejer of the yellow gate, loring us that pirture, that we may riew it. (Soess the perture.) $A l_{1} !$ how has lie dimmes the purity of the

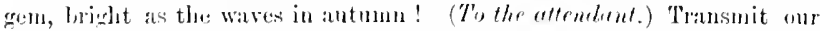

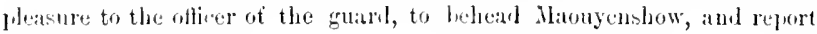
to us his execution."

The traitor, however, contrives to escape forn this tranchent sentence, and, in the next act, flies to the 'Tartar canty with a true likeness of the laty (now 
created a mineess), which he exhibits to the barbarian king, and perstandes him, with ingenious villany, to demime lecr of the emperor. No sooner said than done: an enroy is despatehed by the khan, who alis-" should he refuse, I will presently invade the sonth : his hills and rivers shall be exposed to ravage. Our wariors will commence by hunting, as they proceed on their ray; and thus, gradually entering the fronticrs, I shall be ready to act as may best suit the occasion."

The unfortunate emperor's fondness continues to increase; and the arrival of the Tartar envoy fills him with perplexity and despair. He calls on his servants to rid him of these invalers; but they berail the wealness of the empire, point ont the necessity of the sacrifice, and call on his majesty to consult the peace and safety of his realms by complying with the lihan's demani. He consents, after a struggle, to yield up the princess; but insists on accompanying her a part of the way. In the following act we have the parting scene :-

"Enroy.-Lady, let us urge you to proceed on sour way; the sky darkens, and night is coming on.

"Prin.-Alas! when shall I again behold your majesty? I will talse off my robes of distinction and leare them behind me. To-day in the palace of Hān; to-morrow I shall be espouserl to a stranger. I cease to wear these splendid vestments; they shall no longer adorn my beauty in the eyes of men!

" Enroy.-Again, let us urge you, princess, to depart; we have delayed but too long alrearly !

"Emp.--"Tis done! Princess, when you are gone, let your thoughts forbear to dwell with sorrow and resentment upon us. (They part.)Aud am I the great monarch of the line of Hän? 
"Presid.-Let your majesty eense to dwell with such grief upon this sulject!

"Emp.-She is gone! In vain bave we maintainel those armed herots on the frontiers. Mention but sworls and spears, and they tremble at their hearts like a young deer. The princess has this day pritormed what belonged to themselves; and yet do they atfect the semblanee of men!

"Presirl.- Your majesty is cutreated to return to the palace; dwell not so bitterly, sir, on her memory ; allow ber to depart!

"Lims.-Dill l not think of her, I hadl a heallt of iron-wa heart of iron! The tears of my grief stream in a thousanl channcls. This evening slatl her likeness be suspender in the palatce, where I will sacrifice to it; and tapers, with their silvery light, shall illuminate her charnter."

Then comes the catastrophe. The Tartar amy retires with its prize, and they proceed on their marcls towarts the nortl, nutil they reate the bankis of the river Amoor, or Saglalien, which fialls into the sea of Ocluotsi.

"Prituerss. - What place is this?

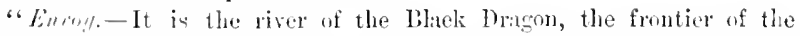
Tartar territuries and throse of China. This sonthem shoure is the

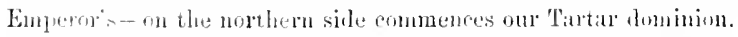

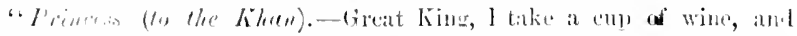

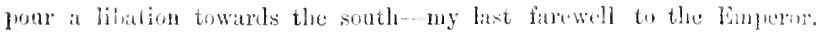

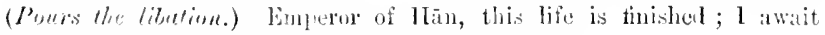
thee in the next! (Therows lecreif into the ricer.)"

The lady is drowned, and the klan, in grat somow, decrees that her sepmlelure shall be planere on the river's bank, and ralled "the verolant toml,." This is salil to cxist at the jusesent day, and to remain soren all the year remurl, while the vereotation of the desert in whirh it stamels is fatredere ly the smmmer sum. With more

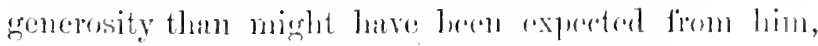

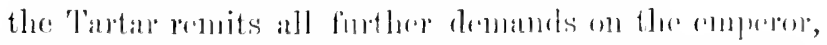
and directs that the wiclied canse of these misfontmos 
shall be dilivered orer to the Chinese, to receire the just reward of his miskededs.

The last act opens with the grief of Yuente at his recent loss: and the princess appears to him in a vision, which vision, however, is not a whit more extravagant than the similar secue in our own tragedy of Richard III.-crnm multis nliis. But let our readers judge for themselves.

"Emp. - Since the trinces was yielded to the Tartars, we have not hell an awlieme. The lonely silence of nirht inereases our melandholy : We take the picture of that fair one and suspend it here, as some suall sulace to our grief. (To the attendunt.) keejer of the rellow gate, behold the incene in gonder vase is burnt ont ; hasten, then, to arld some more. Though we cannot see her, we may at least retain this shatow, and, while life remains, betoken our remard, but, oppressed and weary, we would fain tike a little repose. (Lies down to sleep.)

(The Princess appars before lim in a vision.)

"Princcss. - Deliverer over as a captive to ajpease the harharians, they would have conveyed me to their northern country; but I took an occasion to elude them, and have eseaped back. Is not this the Emperor, my Sovereign? - Sir, behold me again restored.

\section{(A Tartar soldier appears in the visima.)}

"Sold. - While I chanced to sleev, the lady, our captive, has made her escape, and returned home. Is not this she? (Caries hor on.)

(The Emperor starts firm lis slerp.)

"Emp.- We just saw the Princess returned; but alas, bow quickly has she ranished! In bright day she answerer not to our call, lut when morning dawned on our troulfled sleep, a rision presented her in this spot. (Therrs the vild-fort's cry.) Hark! the passing fow screancoi twice or thrice! Can it know there is one so desolate as I? (C'ries repeated.) Perhals, wrorn out and weak, hungry and emaciated, they lewail at once the broar nets of the south, and the tough bows of the nortl. (cries repeated.) The screans of those water-birds but increase our melancholy!

"Attend. - Let your majesty cease this sorrow, and have some regard to your sacred person.

" Emp.-My sorrows are leyond control. Cease to uplraid this excess of feeling, since ye are all subject to the same. Yon doleful cry is not 
the note of the swallow on the earred rafters, nor the song of the variegated bird on the llossoming tree. The Princess has alnandont her home! Know ye in what place she grieves; listening, like me, to the screams of the wikl bird?

\section{(Enter President.)}

"Pres. - This day, after the elnse of the morning comncil, a foreign envoy alpeared, bringing with him the fettered trator, Maouyenshow. He annonnces that the renegite, by deserting his allegianere, led to the breach of truce, and oceasioned all these ealamities. The Princess is no more:-and the Khan wishes for peace and friemblip hetween the two nations. The envoy attends with reverence your imperial decision.

"Emp. - Then strike off the truitor"s heal, and be it presented as an offering to the shale of the Princess! Let a fit limpret be got ready for the envoy, weparatory to his return. (Recites these erries.)

"At the fall of the leaf, when the will-fowl's cry was hearl in the re * cesses of the prilice,

Sind dreitus returned to our lowely pillow-we thought of her through the night :

Her verlitht tomb remains-lut where sluall we spek hrrest?

The grerfidions painter's heal shall atous for the beaty which he wringel :"

This may, perhaps, be considered as no unfiromialle specimen of dramatic taste in Chinil. One thing, at least, is certain, thit Voltaire comstructed a tragedy ("L'Orpluelin de la Cline") which pleased his fistidlions countrynen, ont of the materials afforded him by a less inviting selection from the "Hundred Plays of Yuen," translated by Pere Premare. The richness of their theatre is proved by a list of two lomedred rolumes of plays, appended by the antloor to his perefiace. It lass been very truly olserered of the Chinese, that, like the rabble of innerial linme, the two things whels they

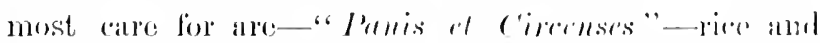
rarec-shows; the policy of despotisun in either anso 
finding it conveniont to fill the bellies and amuse the minds of its suljoets, in order to keep them quict. In China, no sooncr does a famine take place, tham revolts are immediately apprehender; and mess the cravings of the populace can be allated by supplies from the pulblic gramaries, these apprehensions are schlom gromdless. Taught, according to their paternal notions of goremment, to consider the good which they enjoy in prosperity as resulting from the eare of the emperor and his representatives, the people rery naturilly refer the erils which they suffer in adversity to remissness and improvidence in the same quarter; and the government, not ignorant of the danger, is proportionalys cautions in guarding against it.

Another observation or two, and we have done with the Chineses drama. In their play-books, certain words are adopted, to point out the general characteristics of the different dramatis persone, and these particular words are made use of in every play indiscriminately, whether its complexion be tragic or comic. No similar usage cau be found on the European stage, unless, indeed, we except the invariable terms of Harlequin, \&c., copied in our English pantomime from the early Italian theatre,-still marking with precision the station and character of the sereral performers, however varicd may be the action of the piece. The great divisions of a play, or the acts, as we style them, exist, perhaps, rather in the book than in the representation, being, on the Chinese stage, not so distinctly marked as on ours, by the lapse of a considerable interval of time. The 
opening act, or proem, in which the different cluracters introduce themselves very much after the fithom of the Greek tragedy, is called by a mane which means literally a door, or the side posts of a door, and hence metaphorically the opening. The rest are styled brealis. The words sheng and he't, to "alseced" and " descend," are used for enter and crit.

In the department of Romances and Norels, a specimen appeared under the same anspices as the play. The title of the work, correctly expressed in English, is the "Fortunate Union." The term "romance" may be properly applied to any fietion, of which the personages and incilents are above the level of ordinary life. The orthodox rule used to be, that the hero should sally forth, and fight with everything either bigner or stronger than himself; and the preut of the "Fortunate Cnion" really answers pretty nearly to this description. He is attended, too, by a follower, who does him as good service as ever was performed by trusty squire to knight-crant; and, after a multitude of alventures and serapes, produed by the malice of foes and rivals, the heroine is happily and honouralyy mited to her lover, in whom she origrinally met with a protector from her enemies. It may appear stringo that any fietion on so lecritimate a plan shonld be met. with in China-sueh, howerer, is the ease; and it was this eircmustane, joment to the spirit of the dialomene, and the uncrits of the style, which indnerd the translator to nurlertake the task of makiner a complete

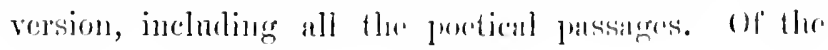


Haoukersehuen, for that is the Chinese title, Sir George staunton expressed a rery high opinion in his miscellaneons notices of China. It is about a century since Dr. Forey, Bishop of Dromore, edited from a manuseript, partly English and partly Portugnese, a sort of skcleton or alstract, rather tham a translation of this romance, and without the poetical passages, under the title of the "Pleasing History," which is not the meaning of the original name. Although it abounded in both errors and omissions, this work, at the time when it appeared, was by fur the best picture of Chinese manners and society that we possessed; and Dr. Perey was not answerable for the imperfections of his materials. He was naturally.puzzled ly some parts of his manuscript, and expresses his surprise in notes at a number of incongruities, which, on a reference to the original, are not found to exist. In fact, at the distance of more than one hundred years since, for that is the date of the manuscript, no countryman of ours could possibly be competent to the task of translation; and the work in question appears cvidently to hare been taken down in great part from the mouth of a native, probably in the imperfect jargon of English spoken at Canton.

The "Fortunate Union" may be considered as a truer picture of existing Chinese manners, inasmuch as the hero espouses but one wife. 'It is not strictly true that their laws sanction polygamy, although they permit concubinage. A Chinese can have but one wife properly so called, who is distinguished by a title, espoused 
with ceremonies, and chosen from a rank of life totally difierent from his handmaids or mistresses, of whom he may have as many as he pleases; and though the offispring of the latter possess many of the rights of legitimacy (ranking, however, after the children of the wife), this eiremustance makes little difference as to the truth of the position. Even in the present romanee the profligate rival of the hero aims at effeeting his mion with the heroine only by setting aside his previons marriage with her cousin as informal. Any Chinese fiction, therefore, and of these there are many, which describes a man espousing two wires, is in this respect no trner a picture of existing mamners than in respect to any other amnsing or silly extravaganee whieh it may happen to contain. These olserrations are not hastily made, being the result of careful cximination and infuiry, and the "Fortmate Lnion" affords suflicient corroboration, were any' required. The resolution of the unfortunate seholar to suffer death rather than allow his dimghter to be degruted to the rank of a liandmaid, even to a noble, and the attempt of the same noble, towards the conchusion of the story, to espouse the heroine as his wife, herouse he hatd just lost his former spouse, are alhmolant confirmation of what we arlvance. In faret the rifo is of cepull rank with her husband by birth, and esponsend with recrular

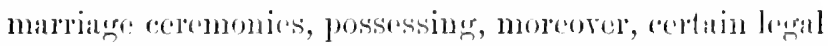
rights, such as they are-the homdmain is bought for

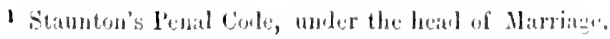


money, and redived into the house like a mere domestic. The principle on which Clinese law and custom admit the oflispring of comeubinage to legitimate rights is ohrious the importance which attaches in that comntry to the secming of male deseendants.

Many remarkalle points of rescmblanee will be discovered letween the "Fortunate Lnion" and on own novels and romances. Every chapter is headed by a few verses bearing some relation to its contents, and some appropriate lines are occasionally introduced as embellishments to the story. After a corresponding fashion, too, with the designations of persons in our own farourite fictions, we should find, on translating them literally, that most of the names in similar Chinese works have some allusion to the characters of those who bear them. Thus the hero of the Haonkewchuen is named from iron (quasi Ironsicte); the literal inport of the heroine's mame is "Icy-hearted," a term which in her country implies chaste, and not what we slould call cold-herrted; her father's designation literally means " Twelling in singleness of purpose," which sufficiently expresses his inflexible character; and so of many other appellatives. The most adrantageous point of comparison, however, lies in the spirit of the dialogue, for which the "Fortunate Union" is distingruished abore any Chinese work of the lind hitherto translated, and we proceed to make some extracts from it. In the ninth chapter the rorthless mele of the solitary and secluded heroine hears some false rumours to the disadvantage of the hero Teilıchungyu, and being a bitter enemy 
of his, proceeds mith great glee to inform the roung lady:-

" 'Niece,' sail he, 'have you houl the strange news?' She plealed the retirel life of a female in her situation as a sufficient reason for leeing igmoraut of what wats ]nssing alroal. "Well, then, continueil her unele, 'you must know that when I advised you to mary Teihehungy 1 hat the best opinion of his elaracter; most fortunately, however, you refuner steadily to give a hasty asient-your hapluness woulh otherwisc lave leten runed for life: ean you gutss what sort of jerson he lats profed himself to be?' 'I know nothing of his birth and fanily, 'replied the young laty:; 'but from what I lave olserved of his conduct it would plainly alyear that he is a roung man of extraordinary virtue.' 'of extraorlinary virtue, indeed!' exclamed the other, im]atiently; 'you userl to have some share of penctration once, niece! - what has heerme of it on this oceasion?" 'But how has le lelied his former character?' inquired Shueypingsin. "Why, he is nothing better thatn a practised sechetr, rejlied her unele. 'I know not what seluemes he might have had in view when he fretended sickness, and eninerl a louging in this house; but you may comsider it the height of goed lurk on your lart that he was obliged, ly the somml rating I gave him, to desist, awl took his departure in an atterted jasion. The

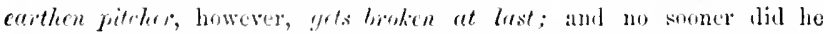
reach the meighlouriug vitlize than he lectrayed hinself.' 'l'ray, what was it he dif to leetray himseli ?' asked the young lawly."

\section{Ife now relates to her the story that he hat heard,} and talies care at the same time to put in some embellishnents of his own.

" 'Well,' sainl his niece, smiling composcully, "let Teihchungyn he what you say he is ; it concerns myself no more than if the favourite disciple of Confurius haw really lecen proved to be a muderer.' 'I know it does not conern gou!' exclatined he; 'but this event shows how very

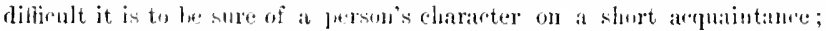

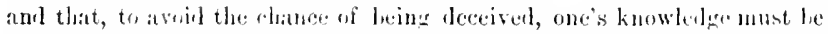
lectler foumbel than on a rastal meeting.' 'In a matter with whi.lo I have

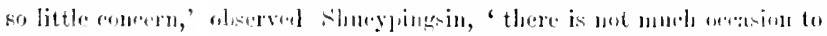

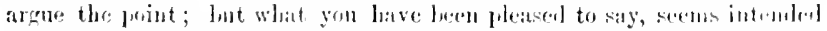

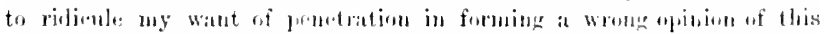

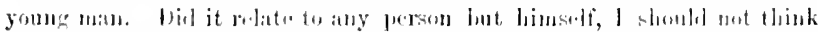

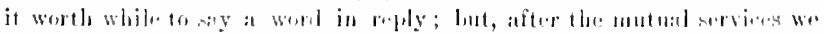

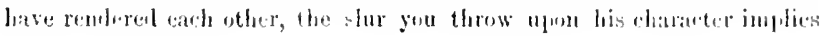


that our acquaintance was dishonet, and slanders my own reputation equally with his. I have, therefore, a gool reason forie repulling it,' 'I

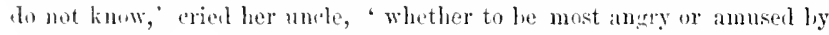
what you say. I never had any eanse of cumity towards this youne man;

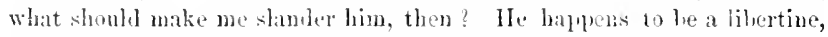
anl entices away a young woman. You live quietly at houle, and know nothing about it ; hat the people near the magintrate's office rejort it to me: why hame me on their aceount! If you choose to say that you mintook his character, and that this was a thing you could not hell, I can understaml you : but if you attempt to maintain that lue really is not guilty, I sulect all the water in the fellow River will never wash him clean from the imjutation.' 'If I think it worth while to maintain anything, replied shuevpingsin, 'it will be that he is not what you cill him, and that the whole is the slandernus invention of worthless people. You may then learn that I was not deceived in ny gool opinion. Any other point I to not think it necessary to arme.' 'My gom niece, you are very olstinate, saiul Shueyun. 'That he is cuilty, has leen proved by a number of witnesses. What is there for yon to say on the sulject?' 'You assert that it has been proved hy mitnesses,' answered she; ' and until we hear something authentie, I will not lebate the point with you ; but, judging from reason and principle, I must still maintain that this young man eannot be what you say; and though such a relort may have gone ahroal (aduitting that it be not a falrieation altogether), there must Yet be something more in it than has come to light; for, shonld he really prove to he guilty of the charge, I will engage to forfeit both my eyes to sou.' 'Why, the woman he carried off has leen apprehended in his compang,' exelaimed Shueyun, 'and taken before the village officer, who transferred them both to his superior. They are now on trial-there can be no fabrication in this. Your attempt to rindicate his eharaeter, after matters have reachet this point, proves only that you are binded by excess of love.' 'It is vain attempting to persuade you at present, uncle,' sail the young lady; "but do not be too positive. Inquire a little farther, and you may arrive at the real truth.,"

The result is, as usual, the entire discomfiture and confusion of the unhappy uncle, whose character for low cunning, and mischierous intrigue, is in perfect lieeping throughont; and the same remark applies to all the personages of the romance, of every description. We will give one more scene, from the fourteenth chapter. The hero Teihchungyu discovers, by accilent, that one 
of the emperor's generals, at present uncler sentence of death, in consequence of certain reverses which he hard suffered on the frontier, is the rictim of combinations and intrigues among lis enemies, and fitl of resentment at such injustice, wallss straight into the court which has condemned him (of which on hero's fither, by the way, is a member), and there stontly pleads the lettler"s canse.

"The three members of the triple cont hat not rentured, aftur the

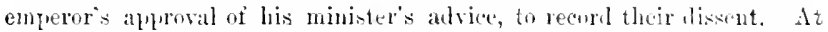
the same time, however, that they confined the sentene of helkan!ing, and waited only for the Imperial warmant to execute the sane, they stih felt a secret uneasiness at the prisoners fitte; and when at jeron was seen entering the eonrt, and thus loully addrewing them, they experiencen? a mixed sensation of alarm at the disturlanee, regert for their sentence, and reacutment at the intrusion. Discovering, on at cliner viww, that it was Teiledaneyn, the other two members felt unwilling to be harsh; he his father struck the talle with fury, and rated him in romed terms, de-

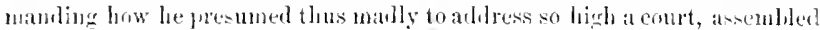
there by Imperial connuision to deciale on a capital atse. "The laws almit of mo private feetings, cried he, and ardered the intrules into

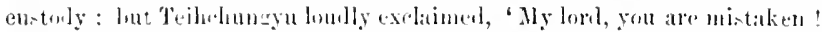

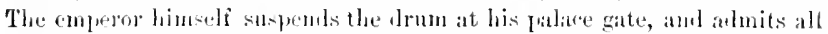

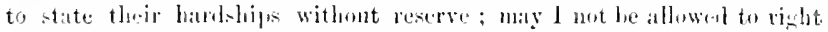
the injured lefore this very thilunal of life and death!" "What have.

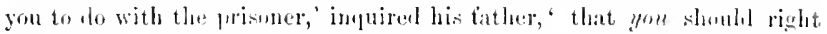

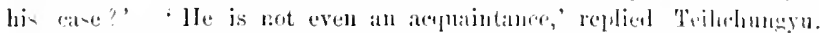
'I can have no reasiss on his own acenunt; fout the diflienly of fimdine

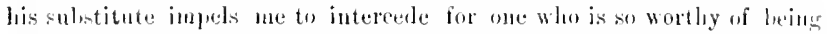

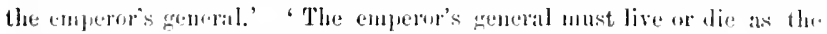

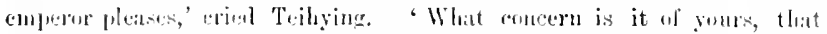
you may behave in this mat style? Seize him instantly!' 'T'lu.

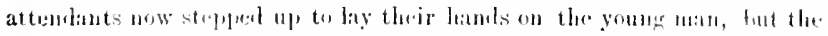

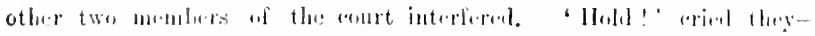

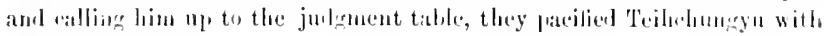
goond worits.

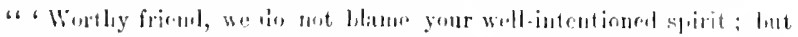

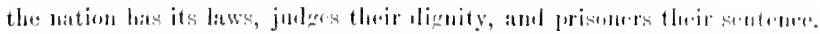

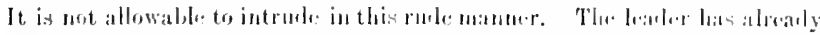

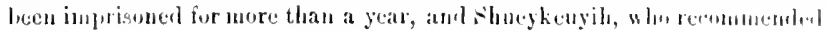


him, exiled on his aceount. Itis offenees being proved hy screral comcurrent atuthrities, how slatl he now he fouml guittless by his jumlges? The matimis laws, the julges' lignity, and the prisoner's cake, alike forlid this! Mlunittine, however, that we proposed a mitication of his punishment, it wonlul be impossille to remit the heaviest prit of the sentence. But the minister has alvised his decapitation-the emperor has assented -low, then, slatl we attempt to oppose it?'

“ 'Alik, 'replied Teihchungyu, sighing, 'your lorkhip's worls would better leeme those ordinary ministers who abanden what is riglit for the sake of their places, their emoluments, or their personal safety: they pertain not to that disinterested spirit which ilentifies your country's welfare with your own! Were the truth as you state it, the lowest callatcity minlit be more than sufficient to conduct the business of the state: what need of personages of your lordshipis weight to minister for the sovereicn: Let me ask you, what meant that saying of the ancient emperor, "Thrice lie death delayed,'" or of the ancient minister, 'In three cases only he death inflexibly awarded?' Your reasonings, if true, would go far to le lrive these sacred characters of their repntation for wishom.'

"The two otlier julges answered not a worl, but his father loroke silence, 'Foolish boy, say no more! This man's death is ineritable.' Teihchungyu, however, rejoinerl with warmth, 'Brave men anl worthy leaders are the rare productions of hearen: if your lordships are inflexible, and lersist in condemning Howhe:lou to death, let me entreat you to condemm me with him!' 'But his guilt and incapacity have been proved,' said Teibying, 'it is only condemning a worthless servant: is there anything extraorlinary in that?' 'Men's capacities are not so easily known,' said his son ; the courage and ability of this learler are such, that, if lie be re-appointed to the frontier, he shall prove another " wall of a thousanl leagnes "-no hero of the age may compare with him.' 'Allowin his capacity to be great,' olsserved the father, 'his delinqueney is still greater.' 'The allest lealers,' said Teihchungy, 'must ever be lialle to connmit errors; and hence, it is customary for the emperor to reprieve them for a while, that they may redeem themselves by acts of merit.' 'IBat in that case,' remarked one of the judges, 'somebody uust be surety; will you venture to be answerable for him?' 'If Howheion be restored to his command, replied he, 'I entreat that my own heal may answer for his misconduct, as the jast punishment of such

1 Such is the actual practice, in ordinary cases, at the present day ; first, by the local magi-trate, who refers to the provincial julge; next, by the provincial julge, who refers to the criminal tribunal; lastly, ly the criminal tribunal, which refers to the emperor.

2 The Chinese name for their great wall. 
rashness.' The nther two julges now turned to Teilying, am satid, - Since sour londhip's son thus publicly tenders his personal responsibility, it hefits ns to make a formal representation, and rerpest his majesty's lleasure.' Teihying was compeller, under the cirenmstances of the case, to assent to this: the leater was accordingly remumled to prison; and Teihclungsu, being called ulon to enter into a written engagement on the spot, was liked in custory for the time leing."

This novel, or rather romance, is a favourable exposition of whaterer is best in the Confuciatn colle of philosophy and morals; and the conchusion is a complete awad of 'poetical justice' to the good and had actors. All parties, on account of their lauk, are smmmoned before the "Son of heaven" limself, and receive at his hands the proper recompense of their respective decels.

"Teildiuneyu, his bride, and the assemhled court then lowed lown and ackmwledicel the inperial bounty, and the hum of joy and gratulation resemblid the distant roll of thumber. The attemlants han receised their wolere: aml, as they lifed ofi in pars, the ornanental lanterns in all their radiane, the harmonious baml in full souml, and the matrolled

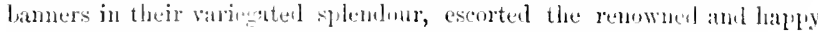

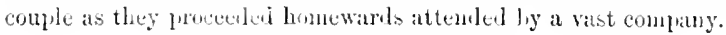

"The dhicest hul, mblown, exhales no swets,

No ruliance can the untried geem displily:

Misortune, like the winter coll that linals

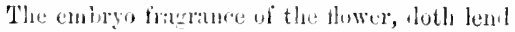

A iresher claru to fair prosereity." 
TT.

\section{ADURES TO THE CHIXI BRINCII OF THE ROYAL ASIATIC SOCIETY.}

aN ITS IXATGLLATION AT HOXGKONG.

Wiтnoct abusing the patience of the Society by any diffuse or trite generalities on the adrantages of those inquiries which it is the olject of this new institution at once to encourage and to prosecute, I shall save their time and my om ly going at once into the question of what is likely to be acquired by the future labours of our members, and by taking a rapid riew of the prospects before us.

It may be remarked incidentally, that, on some points, the neighbourhood of Canton, as a field already gleaned, may probally afford less of novelty in researeh than the more northern localities, which have been open now for about five years, - "depuis" (to use the honest expression of a foreignex") "depuis que par un noble et généreux désintéressement la Grande Bretagne a ourert le commerce de la Chine à tontes les nations."

I will just remark, that if the cursory and imperiect sketeh which is to be presented in this paper shonld prove to be rery difierent from the prounctious of learned

\footnotetext{
1 Count de Pollon.
} 
leisure, or the furniture of "academic bowers," it will be only just to explain its defects by the constant demands on my attention of two separate publie oflices, from whose graver and more imperative calls such digressions can occur only as ehance recreations-as impermissu reptim gumlia, and I may add, in the absence of my books (though not exactly in the meaning of the poet), luminibus remotis. At the same time, the spontaneons proposition of the Society, that I shonld be its first President, was at once too flattering and too congenial to my own inclinations to be declined on the ground of any other than insumomntable obstacles. I will, therefore, elaim its indulgence to my imprerfect serrices in the words of the Seottish Erasmus,-_ "Aceipe, sed facilis!"

Io eommenee with the language of China, ats the key to a great deal that remains to he known. With rewarl to the intrinsic qualities of that very peculiar literature which constitutes the arrehives of this langurage, my own experience does not leal me to be orer samguine in expectations from the finture. My old preceptor and friend, Mr. Malthes, who left behind him an Einropeatu reputation, applicel to some of it (jutging of andse from translations) a remark which is true of a great deal of Asiatic literature,--lhat it was "childisly" ; in firct, a

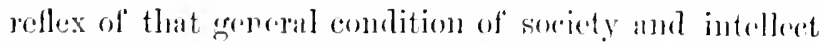
in which it origrinates. Somo of the loest sperimens that contd be discosered of their drama, therir poctery,

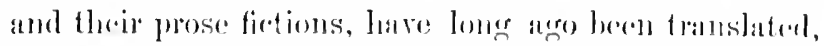
and the chice value of these has eomsisted not more in 
their own alsstract merits than in the light whith they threw on a people so long self-insulated, and shut in from the reach of foreign influence or investigation. Their saceed and historical works, and more particularly the latter, which ar' lane chronicles of events little conneeted with the rest of the world, have hardly repaid the pains of translation.

Some light might possibly be obtained as to Indian history from the Butdhist books, if the recorts which they contain could be made out. Lord Auckland obscrves to me,-"I mention, as a particular olject of inquiry, that Pali phrases expressed in the Chinese character are said to be found in Chinese works, and that Pali works (or coplies of them) taken from India to China between the second and tenth centuries of the Christian era by Buddhist priests, are supposed to exist in the libraries of China."

In its practical uses, homerer, the importance of the langrage has lately increased in proportion to the extension of the field for its exereise. The best proof of this lies in the great accession to the number of persons who make it their study, and who have gained an extensive knowledge of it. The importance of this linowledge in promoting and ailing all our relations with China is sufficiently obrious, and Sir Henry Pottinger informs me in his last letter that there is a growing impression at home to this effect.

On the other hand, in consequence of the umpliant nature of the Chinese medium, and the difficulty of conveying foreign ideas through it, we nerer shall be 
able effectually to impart European information to the Chinese, unless they learn our language. For this purpose, howerer, it is remarliable that there are no less than three separate institutions already in this colony, while I am not aware of any express establishment for teaching Chinese to Europeans, here open to the public.

Abstractedly, and apart from its positive uses, the Chinese, in a mercly philological riew, may be considered as a species of miracle. It is, in fict, the most ingenious and nearly the most perfect applieation of the hicroglyphic prineiple that ean he imagined. The classification and analysis of the characters afford a sulject of endless metaphysical amusement, and a new or additional languige might he constructed ont of the infinite combinations of their distinct constitnent portions. (See Article IV.)

I am alle to hand to the Society a paper, drawn up by Sir George Staunton, of gencral hints as to varions points of inquiry to be suggested to residents in China and at Hongkong. The consuls at the five ports hare been instrueted by me to grive erery enconragement and assistance to pursuits of this nature, in conformity with the wishes of Her Minjesty's Govermment.

Under the hearl of arts, we are alrearly too mucll beholden to Chinese ingemity to be altogether withont lope of something from the futnre. The people who appear from the best aceomits to have originated amonis themselves the inventions of munpowder, printing, and the compass, as well as the mmuliketures of silk, frat, and porcelain, must carry into the operations of their pro- 
ductive industry a constitution of mind rich in results, of which something still remains to be linown. It was only a few dars ago that I was shown some white English poreclain very well painted at Hongkong, with figures and flowers by Chinese workmen.

I have by me several letters from the Earl of Aucklind, the active President of the Royal Asiatic Society, in which his lordship suggests subjects on which information would be interesting. "I may premise," he observes, "that in our present state of linowledge regarding the gorernment and people of China, and the arts, manufactures, and agriculture of that country, scarcely any information in detail could be given to us which would not be regarded as valuable. I observe that a Medical Society has been established at Honglong, which it is proposed shall correspond with scientific societies in England. Wight it not be of adrantage to all parties if this society were to place itself in direct communication with the Royal Asiatic Society of London?" The Medical Society seems, from what I hear, to have been the germ in which our new institution originated, and if we should hereafter desire to be anmitted as a branch of the Royal Asiatic Socicty (of which I happened to be one of the serenteen or eighteen original members, in 1823). I camot doult of the accession being welcomed by that body.

It appears to mrself that one of the most promising departments of knowledge which have been opened out to us since the war is that of natural science, and that the mineral, regetable, and animal kingdoms (to take 
them in the aseending series) afford a comparatively mexhausted field for research.

Geology, indeed, considered as the ancient record of our planet, "rich with the spoils of time," camnot be expected to mroll one of its most interesting or alluring pages in the east and south of China. The primary, unstratified, or non-fossiliferous rocks, which there seem almost exclusively to prevail, contain none of those remains of organized existence, vegetable and animal, in which the more recent formations of our ou'n islend are so rich-having given birth indeed to that remarkable rule, "that the surest way of tracing the same furmation in different comntries or sitnations, is not by the identity of structure, but the identity of the fossil remains containcd in it.'

Of the secondary formations-the fossiliferous strata -in which the remains of organized existence show themselves, the highest or most recent that we have yet hearl of in our neighbourhood are the coal-beds, which Sir Thomas Cochrane's visits to Formosa have proved to exist near the northern extrenity of that country, at Quilon or Kweiloong. Some Formosam coal (of which a specimen is on the table) was lately brought to this colony and sold at 15 rupees or aloont 30 shillings a ton, but will in all probalility be obtainerl much cheaper. It is necdless to insist on the inportance of such resomees for om steamers. Now laere the protical value of greology may comme into play, by conbling persons to follow ont those rertain indications which are aflorded by the struta that 
invarialbly lie in immediate contiguity to coal-beds, and which are a much more infullible guide to hypogene discorery than the divining wand of Dousterswivel in "The Antiquary."

If the Primary rocks of China are in some respects deficient in geological interest, they form a class that is rich in metallic treasures, and for some time past the govermment of the country has evinced an extraordinary desire to discorer and work additional silver mines. During my stay at Florence, in 1837, I spent some time in the Grand Duke's IInseum of Natural History, where, in the department of Minerals, there is an admirably arranged series of metallic substances. It so happens that I have by me the rough notes of observations which were made on the spot, and I will produce them here to show that the sites in which metals are found, or what may be called their habitats, are principally the granitic and other Primary rocks. The substances with which they are usually combined or alloyed when not in a native state are added.

Platina.-Found in tranite rock-native or in company with iron.

Gold.-Whe Primitive rocks- native and often mixed with the sands of rivers; of course a mechanical result.

Silier.-The granite rocks, and carbonate of lime-native or combined with sulphur and antimony.

Mercury.-In quartz, and in the primary calcareous rocks-native, or combined with sulphur and sulphurie acid.

Lead.-The granite rocks, fluate of lime and carbonate of lime-comlined with sulphuric acid, with crome, carbonic and phosphoric acid, and with molyblenum.

Nickel.-Found in quartz and carbonate of lime-combined with arsenic--a coustituent of aërolites, or meteoric stones.

Copper.-In the granite rocks, in carbonate of lime, and abont roleanoes, in union with sulphuric acid. In the natural state, when pure, 
nothing can exceed the fine crimson colour. It is foumt as an oxide, and also comlinel with pyrites, zinc, the arsenic, muriatic, and cartunic acids; and as a curbonate abounds in China, in the shape of muluthite, which is folind in lime rocks.

Tir.- Exists in company with quartz and mica, two of the constitnents of granite-almost always as an oxide, for we learn from experience that tin rusts almost as readily as iron.

Iron.-In the ranite rocks and in carbonate of lime. It is fouml generally as an oxide, but the Grand Duke's museum contained some tine crystals from the Isle of Elha in the neighbourhood. These the ltalians eall origisto, I presmme from their rarity.

Zinc.-In the gritnite rocks-found as an oxide, and comlined with carbonic and sulphuric arirls.

bismuth. - In the primary rocks-exists native, as wetl as comtined with sulphuric acid, and also as an oxide.

Cobult.-Found in the granite rocks, and in carbonate of lime-exists as an oxile, and in couldination with arsenic acid. With this substance the Chinese prepare the blue culour of their porcelain.

I may here lemark, as a motive to the Society to collect a musemm, the rreat use of such collections in concentrating. and thus subjecting to observation in a condensed view, the more rare or interesting productions of the natural world. Buffon himsell is said to have conmenced lis carcer from the moment he became intenclant of the Musem of Natural History at Paris. "Jues lors," says his biographer, " lardemr de Jinflon se fixa sur un seul oljet-etndier, emrichir les dépots d'histoire naturelle, et, a cotéde ceséchantillons tonjours si incomplets de la natmer, dérire la nature elle-néme, en raconter l'histoire, en expliquer los lois, en retracer les monmments." Such a depot Jesides lass the arlvalutare of smply lying a place of reception to masy oljects which would otlecrwise become lost of destroyed.

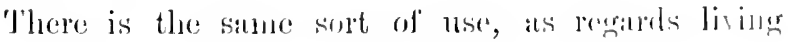


plants, in a small botamical garden, for which I should he willing to grant (and I feel persuaded H.MI.'s Government wonld sanction it) a moderate piece of gromel. Lord Anckiand wrote to me when leaving England,"since I saw you I have had some communication with the Colonial Secretary, who seems to be most farourably disposed to the view which I have taken, and who will, I trust, give his official authority to the proceedings which I have in vier. I wish that he may be led to sanction a moderate expense for a garden at Hongkong, which may serve as a depot for the introluction of plants to China, and for the transmission of plants to Englancl." An official dispateh was sulsequently addressed to me from the Foreign Office conveying a general authority for the encouragement of scientific and literary pursuits in this country.

I have now in the gromul attached to my house three flourishing plants of the European olive, brought out by Mr. Fortune of the Horticultural Society. It is satisfactory to see them thrive so perfectly in this climate, for, according to the Grecian fable, the olive was deemed the best gift that Ninerva was able to confer on mankind; and at the close of a war, whose object it was armis exposcere pucem, this was the most appropriate and auspicious symbol that England conld send to China.

We mar hope that XIr. Fortume's last valuable collections reached home in safety with himself, as the

1 On the China medal. 
supplement and completion of the previous consignments which he had made. But his stay was of course too brief to exhanst the boundless stores of botany which must still remain to reward research, in a comtry to which we are already much beholden.' With regard to what may now be called the old and new systems of botanical classitication, every one will choose for himself; but the scheme of Limnens secms for some years to have lost something of its authority in competition with that perfected hy Jussieu. Indeed, in the botanicil garden at Geneva I could not pereeive any allusion to the Linnexm plan. By an amateur of the seience they maly both be valued for their respective merits. The precision with which the Swedish naturalist divided the vegetalle workd into twenty-four classes, determined by the number, sitnation, or proportion of the stamens in flowers, still further suldividing these classes into orders, fomuld on the mumber of pistils, or their styles, is certainly highly ingenions and attractive and what is perlaps most remarkalle in this method, is the finct, that it has completely comprehended, not only the plants known to Linneus, but all that bace berte discosered siner!

At the same time, this system is so entirely artifiedal, that plants which are nearly allied in natme alre sometimes widely seprataterl in rassitication; while, on the other hame, many which are classed muster the salne hear have unt the remotest natural aftinity. I muy

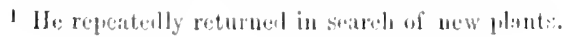


instance the sacred lotus of China and the poppy,they helong not only to the same cless, lut the same order, in the Limnean system: yet the one has been regarded as something sacred by the Chinese, (being in fact a stmbol of Buddhism,) while the other is proseribed and its cultivation prohibited. They have not the most distant affinity in nature.

The Nitural System of Jussien is less of a mere nomencluture, and I may here give in a few rords the outline of its principles from his French liographer. There are among regetables certain natural families, as the oromineous, the umbelliferous, and the leguminous. It having been obserred that in each of these families some of the distinctive organs are constant, while others are varied, the first, as the most important and useful, were made to serve as the heads of the principal divisions, and the others in their turn came in to form the sublivisions under them. By this natural procedure, one certainly arrives less easily at naming any new plant than by the artificial nomenclature of Linneus; but it has been found that the juices and substances of regetables naturally allied have generally similar qualities, and hence the Natural System is a great help in materia medica and economics; at the same time that great aids may be derived from it in gardening and agriculture, particularly with reference to grafting and the rotation of crops, on account of the similar organization and habits of plants belonging to the same natural families.

The most raluable shape for transmitting home a 
new plant is of course in the living state; but there is much less difficulty, and sometimes equal utility, in sending the seeds. Dried specimens of plants answer the purposes of the hortus siccus; while fruits prescrre their perfect shape, and sometimes their colour, in spirits. Some regetable productions, as the nutmeg, are so highly antiseptic that fine specimens of the fruit and leares of that spicy aromatic have been preserved in a bottle of plain water.

Lastly, as to the animal kingdom. The greatest encouragements are afforded by the Zoological Socicty of London to the transmission home of living specimens, chictly of rare mammalia and birds. I have te letter from the Earl of Derby, the president of the society, in which his lordship suggests the promotion of their objects by transmitting home any really new or scarce animals from Clina in a living state, and offer's to defray the charres on their being delivered at Lirerpool, which is not far distant from Knowsley, his seat.

But in cases where the difficulty of transmission, or the mode of capture, renders living specimens impossible, the oljects of plyssiology, at least, may be partially answered in otler ways-lyy the skin or the slicleton of quadrupeds or birds, or in the case of the smallest animals (reptiles especially), by entire specimens in spirits. In this manner sporting may sometimes be marle sulsidiary to science, and the gun may occasionally serve as purvegor to the museun.

The minister Keying scut me from Canton an alult 
male and female and a fawn of what I had hoped, before they arrised, might turn ont a new species of deer; but they prover to be identical with the fallow deer which we have at home. Among the natural productions of this island, I have seen a small variety of the deer kind, a fox, and a civet eat, which last was eanght among the rocks by the sea-side, a circumstance which may seem to imply that it preys occasionally upon fish. It is well that the snakes appear to be neither numerous nor of a malignantly poisonous character. A rariety of the boa constrictor has been proved to exist here; but its size is fortunately not such as to render it formidable.

In the sereral departments of natural history the Society may look especially for assistance from its medical members, in addition to their professional contributions. In language and literature, the increased number and extended range of the new race of Chinese students ought to do something; while in arts and manufactures the ordinary channels of commerce will hardly fail to supply much that is raluable. It is at onee unnecessary and impossible to particularize everything that may be comprised within the sphere of an association like this, whose objects are so general.

I have a note from Dr. Buckland, at Oxford, adaressed to Sir George Staunton, conveying the request of Professor Liebig to be furnished with all possible information as to the details of Chinese agriculture, and especially the question of manures. The whole subject of field eultivation las become of momentous interest, 
since the farilure of one of our main aticles of food appears to have imposed the necessity of a sort of rerolution in a long established system. It is not likely that the proluctions of the extreme south of China would be suited to our climate; but we know from experience that towards the north a great varicty of the cereal and other dry grains are produced in licu of rice, and some of these might be profitaluly adopted as articles of food. ${ }^{1}$

To trespass no longer on your attention, I will merely ald, that the pursuits which it is the olject of this Society to encourage and to cultivite are a fertile source of amusement and ocenpation, and that they are respectable even when mattended with snecess. The useful and heneficial exercise of superior intellect is the main distinction between men and the bute creation, with which the former are so nearly allied in their animal orgmization, their animal wants, and their animal gratifieations, as to have led an amejent philosopher to define man as a mere "lipes implumis," a two-lenged creature without feathers. Bnt the best answer to this bad compliment is the practieal one. In a sense allied to that of the joprolar saying, that " the boy is father to the man," gouth and midtle life may, by the improvernent of time and opportmities, bequeath to age a species of inheritane whing is no hate cont-

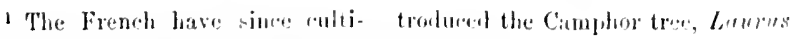

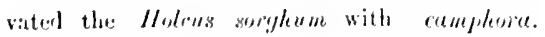
great suecess; inut, moreover, in- 
pensation for the loss of other advantages. Let us believe our old teachers;

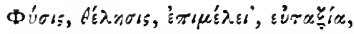

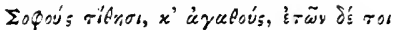

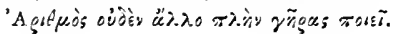

The insulated exertions of individuals, howerer strenuous, must be weak in comparison with the union and co-operation of an associated body like this institution, which I hope will assume a sort of adventitious maturity by being incorporated with, or grafted on, the Royal Asiatic Society. 


\section{YII.}

\section{CIIUSAK IN BRITISH OCOUPATTOK.}

(From the Proceedings of the Royal Goographical Suciety.)

Tne importance of this island was sufliciently demonstrated in its capture on two suceessive oceasions by a British force, and its retention (on the list) for a period of four years, as a guarantec for the fulfilment of the stipulations of the treaty with China. If any allitional considerations could angment the importance of Chusan, it would be the vicinity of the position to Japan, and its intersening between the mainland of China and that other nation which once actually oceupice it, and which is fast hecoming an olject of interest and speculation to the civilized world. Whatever may be the result of the penting American expedition to Japan, it is certain that the new enrent of adventure, settinge westwarl across the Pacifie, most find Jilpan, with Clunsan, the first outpost of the Asiatic contincnt in that direction; and Clnistian states must inevital,y be involved in relations, anicalle or otherwise, with those hitherto secluded recrions. The oligect of this paper was to illustrite a map of Chosan, (oompleted by actual survey during our last orempation of the island, when Brigadier Colin Canpledl (since lord 
Clyte) had the command, and to add such other details as could be eollected from varions somrees (chiefly through Dr. Gutzlaff') in sereral risits to the spot. The last was in 18th, on my surrendering Chusan to the Chinese Govermment, after the full payment of the indemnity, according to the prorisions of the treaty of Nanking.

The Chusan group appears at first to have been occupied by fishermen. The islands were in the serenth century incorporated with China, although the control at first exercised was of a precarious nature. Tradition states, that an emperor of the Soong drnasty, who held his court at Hang-chow cluring the Mongol invasion, flect to Chusan for shelter. During the Ming, or next Chinese dynasty, the Japanese, then the most commercial nation of Eastern Asia, made Chnsan their entrepot, and carried on a lucrative trade. Having afterwards gone to war, on account of the illtreatment of their countrymen by the Chinese, they took possession of the island, and kept it for many years. This forms a singular parallel, as far as it goes, with our orn case. Chusan subsequently rererted to the Ming, or Chinese dynasty, whose representatives, long after the Manchow Tartars had taken possession of China, songht refuge there and defended themselves. But the Nanchows at length became masters of Chusan and surrounded Tinghae, the capital, with a wall. They made it, moreorer, a naral station, such as it was found by our force in $18 \pm 10$.

The latitude of Jos-house Hill, to the right of the 
landing-place, near Tinghae, is $30^{\circ} 0^{\prime} 24^{\prime \prime} \mathrm{N}$., and its longitule $122^{\circ} 6^{\prime} 24^{\prime \prime} \mathrm{E}$. of Greenwich. The island lies from N.W. to S.E., with a circumference of $51 \frac{1}{4}$ miles, the extreme length being 20 , the extreme breadth 10, and the least breatth 6 miles. The hills, which traverse the whole island with their valrous spurs, render the divisions of the territory natural ones; and the valleys hetween them contain the small towns or villages with their population, which all belonged to the Hien of 'Tinglate, dependent in its turn on the superior district, or Foo, of Ningpo. The town of Tinghine stamels alhout half a mile from the beach, of irregular form, nearest approatching a pontacon ; in length about 1,200 pardeds from X. to S.. and 1,000 in arerage breath. The smromenting wall is nearly 3 miles in circuit, with fonr gates, anch defomited ly an onter gate having a side appromed. The diteh on the ontsinte of the wall is intermptert on the X.W. side by a spur from a meighboning hill, which projects into the town, and forms an casy aceress to an atturling force on that side. Thlis hill ronstituted the hemiquarters of the Cameronian resinent in 1810 . () the arrival of the british force in that pard, the popmlation of 'Tinghate mumbered from $2.5,0(0)$ to 30.0000 .

Epon the s. coast of the island, the plinins ansist mainly of alluvial tratets andined frem the seit, and still

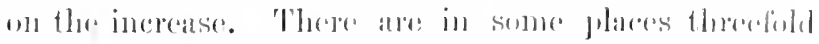

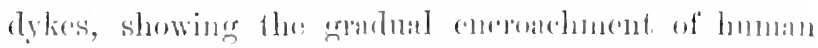

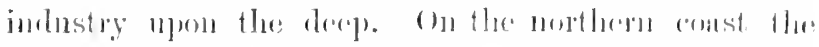
"ase is diflerent; there the seat, uncherlind ly these 
numerons islands which to the S. act as natural breakwaters, heats with gleat violence on the shore, urged by the prevailing N.W. winds; and the inhabitants liave with incredible labour reared solid stone walls in the most exposed spots, to prevent the salt water getting into their rice-fields.

The valley in which Tinghae stands is called Iungtum, and is one of the most extensive in the island, being 4 miles long by 3 broad. Standing nearly on a level with the sea, and copionsly irrigated by canals, it is well suited to rice cultivation. It is enclosed along the S. front by an extensive dyke. This was, in 1811, considerably raised, and converted into a line of batteries, which our force easily took in flank, much to the surprise of the Chinese, who expected us to attack them in front.

The Map of Chusan shows the direction of the mountains rumning principally across the breadth of the island. The greater part of the surface is hilly ground, in geological character generally corresponding with the adjacent gromp, and consisting chiefly of granite. No rolcanic traces have yet been discovered, although sereral of the Japanese islands, at a short sailing distance, are of that class, and among them Sulphur Island has an actually burning crater.

On most of the hills there is a moderate coating of earth, which permits the growth of grass and fir-trees; and industry has improved these natural adrantages to the production of sweet potatoes and other regetables. The climate of the island, in $30^{\circ}$ lat., is admirably 
suited to the vine, as are also the declivities of the hills; but the Chinese make little or no wine from the grape. Bamboo groves are planted, notwithstanding the comparatively high latitule. The tea-shrub grows in many places luxuriantly. An exception occurs in the highest ridges about Secou-shu, Chac-ho, and II Aou, which are comparative barremness, fit only for herds of goats. In some places artificial terraces have been constructed, and, as the supply of water is considerable, the earth thus retained by stone walls produces good crops of rice. The inllabitants have been very diligent in the construction of pared paths across the hills, which facilitate the communieation at all seasons of the year. There are also small Buldhist temples luilt in these passes, where the passenger is supplied with tea, the leaves of which the surrounding peasantry contrilunte gratuitously.

At a distance these clevations often look very wild, but on a nearer approach it is fomd that no soil has been lost, the smallest patches having some productive cultivation. Erery poor man may choose an unoccupied spot on the hills and prepare the soil for trees or vergetulbles, paying little more tham a nominal rent, and remoining the mulisputed owner as long as le contimues to enltivate it.

'The remome rent of the whole islinel appents to be very light. Aceosliner to a returu obtained by Limut. Shatwell, of the 98th Reginnent (for some time holling civil cmploy), there are three rates of rent, as in tho rest of China. The irrigated gromed, or T'i'll, pays 
ammually per mou, 110 copper coins in money, and something maler 2 catties of rice. The dry ground, or 'T', where corn and regetables are grown, pays 88 copper coins, and abont $1 \frac{1}{2}$ catties of rice. The remaining ground, called Sham, or hills, pays only three copper coins, and nothing in kind. The object of a part payment in grain may be to preserve something like an arerage corn-rent.

There are many small streams rumning from the mountains and crossing the plains into the sea, of which the largest is the Tung-keang, east of the tomn, which reaches the harbour close to Jos-house Hill. At high water the native boats can ascend this only a short distance, to a place called Tung-keang Poo, where a number of merchants carly on an active trade with the neighbouring main. There is not a valley without its stream: some with boats, sluices, and bridges. Many are dry during the summer, but when the rains fall they furmish sufficient water for the canals and reservoirs. The canals in some places form a network, and furnish a supply to every rice-field. Though not constructed by persons of professed science, they prove to have been laid out on the best plan, and are examples of practical skill. It is only within the town of Tinghae itself that these canals are noxious, exhaling most offensively in summer.

During part of the winter the canals of the lowest valleys overflow and corer the fields, though most of the roads and paths are sufficiently raised for keeping up the communication. The inundation which occurred in 
1843, at the commencement of Octoher (during our occupation), was unprecedented. The clouds secmed to come down in a mass, and the water aceumulated with such rapidity that no precautions could abate its violent effects. The western part of the island exhibited a sheet of water, out of which the hills rose as islands. Inmense pieces of rock were swept down by the torrents from the mountains, bridges and causeways destroyed, some of the rivulets changed their beds, while many of the most fertile fields remained covered with grarel; hut on ordinary occasions the sluices are sufliciently adapted to letting off the waters, however great the quantity. The wet and dry seasons here and at Hongkong ${ }^{\prime}$ are reversed : in the sonth the winter is dry, and the flooding rains fall during summer. The difference of lat. about $8^{\circ}$.

As to climate, very aceurate talles were kept during our long tenure of Clnsan. Consirlering the position of the island, in $30^{\circ}$ lat., the average temperature is remarkably lon; but the influence of the sea tempers both the extremes in comparison with the opposite main. In the begrinning of the winter of 1811, while the snow at Ningpo fell above a foot in depth, and remained on the ground for several days, there was a mere sprinklingr at Chusan. North-westerly winds prevail throughont the year, and it is only during . July and Augrast that the hent is oppressive to Europeans.

1 This worl is often written as two scparate ones; but there is no than Chu Siun or Lon Don. 
In 1843 the weather was still so cold luring some part of May as to renter a fire comfortalıle. Nature revires generally about the beginning of February, when the first blossoms of the plum-tree make their appearance. The real flower season is in April and May, when the whole surface of the country is decked in the brightest colours. Cherries are ripe in May, and a great rariety of regetables brought to market, including peas and beans. In June the grain harrest commences, and most of the blossoms diminish. A new cultivation takes place this month. Crops of rice, with millet, coriander, and other seeds, are then sown, and rain falls to July. In September the weather is generally cool and dry, and the temperature delightful in October, during which the last of the rice harrest is brought in. The sweet potatoes are ripe in September. The first hoarfrost is seen in Norember, and during December it often freezes severely; but the ice does not remain so long as on the main. Most of the trees being deciduous, the island looks bleak during the winter. The fanpalm, howerer, grows in the open plains, and even the plantain in sheltered nooks; but this last, thongh it blossoms, brings no fruit to maturity. Opinions were at first very unfarourable as to the healthiness of the climate, and the terrible mortality among the troops in 1840 seemed to justify the worst that could be formed. Certainly the rice-fields, which are nothing but marshes, alternately flooded and dry, might lead to the conclusion that the exhalations must he unfarourable to European constitutions. But in $18 \pm 0$ much of 
the ill effect might be ascribed to the inflnence of the war. The fever was then mevalent among the matives, and carried oft large numbers of them. Subsequent experience, from 1842 to 1846 , when the islant was peaceubly restored, convineed the most doulutiul that the climate is really salubrious, and that the mortality among the troops in 1840 was caused chiefly by the want of wholesome provisions and good lodging, joined to the effects of sumshoo, the deleterious Chinese spirit. Ferers occasionally prevail during the summer months, but they seldom resist the use of quinine. The Scpoy troops from India suflered from the cold of the winter.

In its productions Chnsin does not materially differ fom the adjacent mainland of Ningpo. The sleck and small cattle, and the buffiloes, linger tham those in the sonth, are used exclusively for the plongh, and never slanghtered for the use of the Chinese, so nen to the head-quarters of Budhhism in the neighbouring island of Pooto. The sinall cultivators do not lieep a bullock, but there are men who hine them ont for the value of about 8d. a-thy. There are no grazing pastures, the cattle being driven to the momtans, and receiving very little fodter lesinles. The soil leing rlose and adhesive, ploughing is a diflicult process; hut, notwithstanding the smalhess of the cattle, they are very officient, and more than one is seldem or nexer seen in a plomerh. Horses are not used for andiontural proposes, and the Chinese Government does not allow the commonn pereple

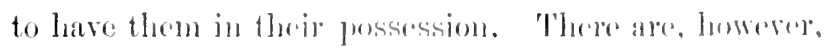

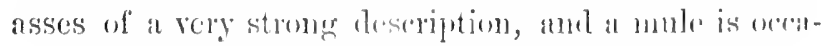


sionally met with. These are used exclusirely for riding, while all burthens are either transported in boats or on men's baclis. A small species of goat is killed for its meat; but they give very little milk, an article of which no Chinese ever makes any use whatever. During the British occupation many flocks of Tartar sheep were brought over from the main, and throve extremely well, but they were killed entirely for the consumption of the English. Pigs are not so numerous as on the main, and are sometimes imported from thence. The dog is of the common Chinese breed, like the Esquimaux variety; and occasionaliy a very diminutive Japanese $\log$ is met with. The island is too well peopled to leave much range for wild animal: - a few small deer seem to be the chief.

Fowls are of the largest description, in fact of the Ningpo breed. Ducks are reared in immense quantities by the peasantry. There are large establishments where the young are artificially hatched, and sold at the rate of forty ducklings for a dollar. Eren geese are hatched in a similar manner. A few pheasants and woolcocks were found by English sportsmen. Wild swans come during the winter in hundreds, and ocenpy the extensive watery flats; as also wild geese and wild ducks. Our people shot snipes in the rice stubble, but they are not disturbed by the natives. The presence of our force, and the demand for game, gradually indnced the Chinese to pursue it, but the principal part comes from the main.

One of the dainties in the waters of Chusan is the 
yellow, or mandarin fish, which, during April, May, and June, is canght round the island in such quantities as to occupy above a thonsand boats. It is a large fish, rather flat, and of a rellowish hue, and, when fresh, nearly as handsome as the gold-fish, with a dorsal fin of the same colour. When eaught it is immediately soli to merchants who are on the spot, with large boats nilled with ice, in which, leing carefully packed, it is taken over to the main, and thus sold all over the comntry. The flesh is good, and when a little seasoned with sauce possesses an excellent flarom, highly estimated by Chinese gonrmands. This fishery forms an important branch of industry, and oecupies a considerable portion of the islanders. A small species of slank, of a dark grey colour, is also caught during snmmer, and, being salted, is sent to other parts of China. 'The shallow, nuddy seas in this neighbourhood abound in fish, and prodnce horring, mackerel, mullet, pomfret, ray, sole, sturocon, and other varieties.

Of reptiles, a black snalke is very common, and found in the fields, but, from the little heed taken by the natives, it may be supposed to be imocuons. There is another large snake that frepuents houses, pursuing rats and other vernin with great hostility; and, as it is harmless, the natives do not discomage it. It is black on the back, with a yellowish-white belly, and grows to six or cight feet in length. The silkworm is reared by only a few fumilies, hut the position and the clinate of the island would insure suecess in a more cxtensivo cultivation of its prorlnec. 
Chusan does not abound in wood. This scarcity is not the fuult of the soil, but owing to the thriftless habit of cutting down all the growth of the hills as it rises up. The most frequent, perhaps, is the useful tallow-tree (Stillingia), spared and cultivated on account of its produce. It is found principally on the banks of streams, where it blossoms in May, and the berries form in bunches, coming to maturity in October and Norember. By this time the leares are of a beautiful red, the pods containing the seeds burst, and these seeds malic their appearance coated with white tallow, and about the size of a pea. Suddenly the leaves fall off, and the trees, from the whiteness of their berries, look as if they were in blossom. The natives then cut the branches, gather the berries, boil and press them so as to make the tallow run into a fat, which, when congealed, resembles the animal tallow, but is less firm and consistent. The island produces a large quantity of this substance, especially in the north-nestern districts, and exports largely.

The rarnish-tree, which somewhat resembles the fig, thrires also rery well in Chusan. The oil or rarnish extracted is inferior to that produced in Ganhoey, which may perhaps be from another plant. The natives excel in applying it to wood-work of all kinds. Their furniture, and the framework of the best building's, are beautifully rarnished; and the durability of the coating is such as to insure its superiority to all oil-painting and other contrivances for protecting wood against the influence of climate and time. The tree might be introduced with great adrantage into Europe. 
The camphor-tree also flourishes at Chusan, and will grow to a large size if permitted. The natives, however, only use the wood, and do not extract the resin as they do on the main. This tree, too, might lee well introduced in Europe, being very ornamental and sufficiently hardy. A lind of elm, of which the blossoms, when dried, are used as a dye-stuff, and much esteemed by the Chinese, grows on the banks of streams. The dwarf fir and oak are as common as the full-grown trees are rare. The banian ficus is even in this latitnde a beautifnl tree, and, as in the interior of China, planted for religions purposes round temples and other public buildings. A slender graceful pine is cultivated for ornament; and the people show superstitious veneration for the eypress, which they plant 'hicfly near grares.' This pecnliar sort is the Cupressus pendulu, or" "weeping cypress," brought to Englind by Mr. Fortune. Tho Chinese say that this tree soon decays, Jut the wood is firm and fragrant, and estcemed by their cabinctmakers.

The natives possess apricot, peach, plum, apple, and pear trees, but take no troulde to improve them, and the fruit is consequently of the most wretched description. The Lornat, and some kinds of ormges, grow well withont much eare. The best fruit in the island is what has been aroneonsly styled "arlutus," which it very closely resembles, both in fruit and leaves, lecing

1 "When I am reat, inter my borly on the brow of simus indre. gucuted hill, and plunt the fir and the repress thickly armunt." -

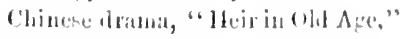
1'. 34. 
at the same time quite a different tree. The Chinese eall it yongmei, and Mr. Fortume says it is"A species of Myriea, allierl to the Himalayan W. supidu, noticed by Frazer, Rorle, and other writers. The Clinese variety, lowever, is much superior to the Indian. Indeed I beliere the Chinese have both, but use the Indian as a stock for grafting on. There is a very large plantation of this tree in Chusan, and the fruit was beginning to be brought to the market during my stay. The trees were hashy, roum hearled, and from fifteen to twenty feet in height. They were at that time loader with dark red fruit, not unlike, at first sight, the fruit of our arbutus, although very differently formed (internally) and much larger."

It is well worth introducing in England.

"The oil plant, Brassica Sinensis (Mr. Fortune obserres), is in seed, and ready to be taken from the ground in the beginning of Haly, and there is a great demard for the oil which is pressed from its seeds. I may state that this plart is a species of cabbage, producing flower stems three or four feet high, with yellow flowers, and long pods of seed like all the cabbage tribe. In April, when the fields are in bloom, the whole country seems tinged with gold, and the fragranoe which fills the air, particularly after an April shower, is delightful."

He adds-

"The flora of Chusan, and all orer the mainland in this part of the wrovince of Chekeang, is rery different from that of the south. Almost all the species of a tropical character hare entirely disappeared, and in their places we find others related to those found in temperate climates in other parts of the work."

That new and beantiful plant, the Teigelia rosea, was first discovered, Mr. Fortune tells us, in the garden of a Chinese mandarin, near the city of Tinghae, on this island. "It was loaded with its noble rose-coloured flowers, and was the admiration of all who saw it, both English and Chinese." It is fortunately quite a hardy plant, and flomishes in the open air in this country.

The tea-shrub is grown almost everywhere on the island, but treated with little care, and left almost wholly to itself. The produce is accordingly of an 
inferior kind. It seldom grows above four feet in height, and occurs sometimes wild among the mountains. The utmost eare taken by the natives is to weed a little round the plants; and so congenial does the climate appear withal, that the plant still thrives, and produces good crops of leaves. There are, on an average, two gatherings in the year. The tirst commences in April, and comprises the young and finer leaves. Old and young women are then busily employed in gathering them, while the nistress of the family keeps up a slow fire under a lirge iron pan, into which they are thrown. When suficiently hated, a strong man receives them into an oval baslict, and kneads them with all his might, in order to press ont the superfluons moisture. They are then spread out on a large frame of wieker work, nuter which a little fire is kept up. This process is repeated after an interval, and the tea is subsernently sorted and pieked, and sold to small merchints, who export it to the minu, principally Soo-chow. The finest trat fetches albont a quarter of a dollar (or one shilling) per catty of $1 ! 31$ h., and suits the Clinese; thongh, on areoment of the slightuess of the firing, it is not calculater for the

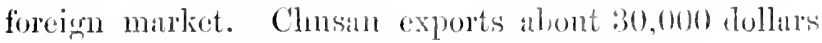
wortl every year, lesirles its own ansmundion.

The bulk of the inhalitants give their whele time to

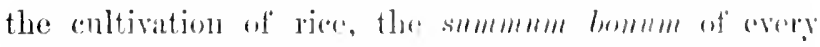
Chinese, whe affects to pity these contrites which do not arow it. Wharesere the snmallest speet ran be com-

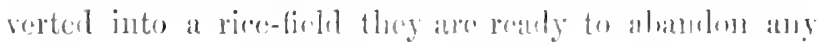


other cnlture, though it might seem more adrantageons. Notwithstamling this, however, there is not sufficient produce for the consumption of the island, and onefourth the annual supply is hrought from Tae-choo. They have the white, red, and no-me, or" old man's rice. The first resembles Carolina rice in the largeness and whiteness of the grain. The seed is first thickly sown in a small bed in the spring; thence it is transplanted into the field in bunches, and placed rery exactly in rows. The greatest care is taken to provicle an ample supply of water, with which the field is flooded; and the tread-wheels are constantly raising water to the different levels in dry weather. Every weed is carefully pulled up, and the appearance of any is considered discreditable to the cultivator. The grain is ripe about the month of Angust: after being first bent down by the farmer, it is subsequently cut off, and thrashed out by beating against the inside edge of a large basket or tub, provided with raised sides, to prevent the loss of the grain. Next it is dried, freed from straw and other impurities, and laid up for use. To disengage it from the husk they pound it in large stone mortars, and then winnow it. The coarser kinds are placed in a stone mill, which is put in motion by a bullock, and a rotatory grinding separates the chaff from the grain. The crop that has been last put into the ground arrives at maturity in October, or even as late as November; but this crop, on account of the uncertainty of the weather, is liable to be spoiled before it can be gathered in. The produce varies from twenty to thirtyfold. 
One of the most graceful and prolific grains in Chusan is the Barbadoes millet, which grows to a great height, and is said to produce a hundredfold. Towards harvest time, when rice is getting scarce, it is made into calies of a reddish hue, and thus constitntes the fool of the people. The large thick stalks are used for fuel. There are besiles two other kinds of millet, of a fine grain and very white, which are used instead of rice.

The wheat is of an inferior deseription. There are two different species, both of which have a low stalk, and one is unbearded. The Chusanites cultivate it like rice, transplanting it in bunches, but without the irrigation. Of the flom they make calies and rermicelli, and use the grain extensively in distilleries. The barley is small, and ground down ly the poorer classes to mix with their rice. Buckwheat is grown in small quantities on the most sterile lands, and also found wild.

The attempts to introduce our common potato succeeded in some measure, but the sweet potato grows so suceessfully on the brows of the lills, that it constitutes a cheap and excellent food for all. The yam and taro are grown, but the latter is small and insipid. The ficlds produce a variety of summer and winter beans, as well as green peas. The radishes, turnips, and carrots are very fine; lut the varicly of litehen verotalles is not great. The lrinjal (at species of solanum) grows in perfection, as well as cabbagr, letuce, and spinach, with enembers, nelons, and pmopkins. Tlere is the large Iretser, or Peling calluage (nore like a lettuce in appearance), which is salted or pickled, and enten 
largely by the Chinese. Ginger, of an excellent deseription, is common, and the coriander seed is cultivated on ridges. The fields, to a large extent, are eovered with crops of mustard, the seeds of which are exclusively used for expressing the oil, a considerable item of export.

The cotton shrub is largely cultivated near the sea, and especially on lands which have been gained from the water, and still contain saline particles. Both the white and the brown, or nankeen, cotton are grown, but the latter only in small quantities. Each is of a rery fine fibre, superior to what is imported from India, but also twice as lear, and by no means of so long a staple. The $y u$, hemp plant, from which grass-cloth is made, grows almost wild, and is cut down twice or even thrice a year for the sake of the fibres. The women, however, do not work it into a texture, but merely spin it into thread, and use it for sowing, probably on account of its strength.

The only walled town in the island is the capital, Tinghae. One-third of the ground-plan of this has no habitations. The level sides of the wall are encompassed by a ditch, that stops short at the hill which enters the city on the north-west. The wall is eighteen feet high and fifteen feet thick, and on the west and east sides nearly in ruins, notwithstanding the extensive repairs by the Chinese in 1841 . The parapet remains in a very fow places. The hill inclosed within the wall on the north-west side is a spur from the neighbouring ridge, and was occupied in 1810 by the 26th, or Came- 
ronian regiment, so many of whom fell rictims to disease, and were buried there. The city is traversed by canals, which are a real nuisince, without any countervailing advantage. The largest street is that which runs in a straight direction between the senth and north gates; the rest are small and short-many of them mere lanes. There are four gates at the cardinal points, forming the ontlets of the principal streets, and also a water gate, between the west and south gates. The buildings are mostly of an inferior description, with the exception of two temples, dedicated to ancestors, and to the guardian irlol of the eity. In the former is the largest representation of buillia that has licen met with. A few of the richer classes lave long rambling honses, walled in within a comt containing a whole series of buillings. The shops of the better traters are very showy; hat the common people have mere mul hovels, or paltry dwellings put togetlere with tiles and stones, without regand to wamth, ventilation, deanliness, or comfort. Nany of them are built in squares: and in a little space, which four Englishmen would limb too narrow for a habitation, there are perlapes forty Chinese huddled torgether. Thinghace would not, in fact, rank with a grod country town in Fingland. Tiefore onr ocenpation it hat a suburb towards the sial, called Themetore, consisting of streets, some woulyards, distilleries, ant stores, all of which were levelled

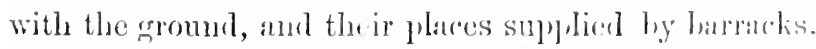
Temple, or Jos-louse Hill, which commands the town and latrour, and was in 1811 so diligently fortified 
by the Chinese, is 800 yards from the south gate, and 122 feet high, close to the beach, with a canal on the east sile. The dyke along the front of Yungtung valley was converted by the notorious ${ }^{1}$ Yulien into a breastwork against an attack by sea, and has since been falling into decay. During our occupation a new suburb, calculated to surpass the old one in extent and solidity, gradually rose up at Tungkeang Poo, some way up the eastern creek or canal, and houses were daily builling there.

The harbour of Chusan is formed by the island itself on the north; Trumball and Macclesfield Islands on the south; Grove Island and Beacon Rock on the east; Guardhouse and Tea Island on the rest. It is well landlocked, the water rarring from four to eight fathoms; but the currents are strong, with not very secure holding ground; they run nine lnots per hour.

The largest place next to Tinghae is the torn or village of Seaonsha ("Little Sandy" Talley), a manufacturing station, where they make agricultural implements. Ta-chen has also a small tomn, as also Selica-mun to the east, and Tsinkiong (or Sinkong) to the west. By far the greatcr portion of the population lives in rillages and hamlets, which are scattered all orer the island, and found in the most secluded spots. The richer landholders generally assemble their tenants in a very large inclosure, where a whole clan lires together with children and children's children, and this generally constitutes a village in itself.

1 China during the War, and since the Peace, rol. i. p. 184. 
The people of Chusan are shorter than the Chinese on the main land; and there is no doubt of a considerable mixture of Japanese blood erer since that people possessed the island. It is well known that the Japanese are universally of short stature. Though often strong-limbed, the Chusinites are not a fine race. Their women are particularly unattractive: for owing to the habit of drawing their hair very tight, or some other canse, they lose their hair early, and become bald. The materials of dress are generally the same in both sexes. In summer they are clothed in grass-cloth (called IIea-poo, or summer cloth), mostly dyed line, and some wear next to the skin a strange gillment composcd of a lamboo network; that is, small sections of bamboo (like bugles) formerl with string into a species of net, which prevents the mper garments coming into contact with the body. On festive ocealsions they are grilly decked out with the help of embroidery. The better clisses wear the fine stutis of Háng-chow and Soo-chow. Since the introduction of our calicoes the cleanliness and comfort of both sexes have advanced; and this applies to the lower orders as well as the ajper. In winter they wear stufferl cotton dresses, mostly of light-blue colonr; a few, also, shrepskins, and the more respectable classes, fiurs, which, during onr stay, gradlatly grave way to broadeloth and cambets. The lower orters dress by no means so extensively in woollens as the rheapeness of om loneells might lead one to expect ; and this is the more surprising as contrasterl with the considerablo consunup- 
tion of English cotton goods. A thick and coarse kind of Russian eloth was much in use; but of late the merchants of Ningpo, as well as the people of Chusan, scem to have preferred our manufactures, which, though thinner, are more durable, and retain their appearance longer than the Russian. The general introduction of woollens must be a work of time; but, as a proof of the growing consumption, may be mentioned the great falling off in those silk manufactures which were formerly used as either linings or covers for fur dresses, as these were worn outwards or inwards.

Few ragged persons are met with; but the thrifty housewives understand patchwork thoronghly, and the warmth and thiclness of the garment increase in proportion as it is mended. The under-garments of all classes are generally in an abominable state; nor are the richest ashamed of rermin and cutaneous diseases.

All classes of people are gross feeders; and, strange to say, the only articles of food for which most of them entertain an arersion are beef, milk, and butter. This seems originally gromnded in the old Buddhist superstition, in regard to the flesh at least. Rice is the basis of the daily food of all, eked out among the poor with barley, sweet potatoes, and millet. They have three hot meals a day; and even the beggar has a number of small messes with which to season his rice. The richer classes, even on common occasions, hare as many as twenty small saucers before them, containing pickled fish, cockles, salted regetables, soy, and similar condisnents. The sea furnishes the largest quota in this 
account, and the ingenuity of the people in preparing these marine delicacies is remarkable. Whatever is highest seasoned and most pungent pleases them best. The consumption of meat is but small, as in the rest of China; and even pork, in such general use elsewhere throughout that country, is but sparingly eaten at Chusan. On the occurrence of festivals they prepare dishes which, in point of elaboration, might rival the productions of finished cooks; and it is by no means uncommon to see as many as serenty following each other in succession. Generally, however, they are very moderate in their habits. Even the use of the distilled spirit called samshoo, so general on the arrival of the British, rery much declined subsequently, in consequence of the many restrictions it became necessary to impose for the sake of the troops. The consumption of opium was rery small in comparison with that at Sincapore and Hongkong.

The town of Tinghac and its suburbs had at the commencement of 1843 about 27,500 inhabitants, including men, women, and children; a large number, considering the small extent of buildings. But even this large number, strange to say, under the government of foreign conquerors, increased towards 1816 (when the island was restored) to abovo 35,000 . Our census did not extend to the whole ishand, of which the population can only be ressumed at 200,000 lescirles. Notwithstanding the general fortility, and the cultivation of rice in every nvalalile nook, considerable importations of grain are repuired. 
Dr. Gutzlaff, who was for some time civil magistrate at Chusan, reported that

"Nine-tentlis of the inbabitants live from hantl to mouth, upon a very miseralile pittance. I lave gone from eottage to eottage, from hovel to hovel, in orler to satisfy myself alont the means of sulisistenee among the majority of the labouring classes, and found it at a very low level. An artizan, who unlerstands his work tolerably well, receives, besides his daily food, alout bin copper cash (the twentietl part of a dollar), or $2 \frac{1}{2} d$. With this lie lias to maintain his family; hut they contrive to subsist npon such a pittance, and the reason is, that the wives understand how to cke out a tritle; and the chiluren, almost as soon as they can walk, are tauglit to contrilute something to the common stock. Eren under such rinching porerty they are seldom heard to grumble, seeming to understand their duties better than their rights, and never looking to others for aicl as long as they ean move themselves. The porerty met with in the houses, accompanied by unahated cheerfulness, is a characteristic of the Chusanites. ${ }^{1}$ When, after haring prohibited legging in the streets, all the paupers of the island were collected, we had about seventy individuals, and these were either old decrepit men and women, or blind and maimed people, who justly claimed our charity."

Any one in the town may carry on what business he chooses, haring first serred an apprenticeship, and been for some time a journeyman. In the country ralleys, however, the poorer classes depend entirely upon the more prosperons landholders, and, though slavery does not exist, they have to work as hard as any slares. There is no legal restraint; the bond is merely social, the landlord being in some measure responsible for supplying his peasantry in time of scarcity with provisions at a certain rate. There is an extraordinary restriction as to the transport of grain from one valley to another (just as there is in China, from one province to another), because it is believed

1 Perhaps of the Chinese in general. 
that if this transport were allowed, the price in the immediate neighbourbood would rise. Owing to this absurdity, the price of rice in Chnsan itself varies sometimes surprisingly in the respective distriets.

The Chusanites are not fond of the sea like the people of Folien; but on land they resemble their own buftaloes in the patience with which they tread daty after day through their inumdated rice-ficlds. Being able to bear much fatigue, and perfectly hardened against the inclemency of the weather, they are sulject to few discases. The two that prevail most are "jungle ferer" and elephantiasis. The furmer is at times very malionant, and carries off numbers in a short time, as was the case in 18t0, partly perhaps the consequence of the war. 'Tlle latter displays itsolf in the swollen legs of the patient, which increase in size gradually until his death; though this complaint, howerer incurable, does not seem much to shorten life, as many who are afflicted with it reach old arge.

No male alyove twenty years of age remains single if he ean help it, and the women are married as early as sixteen. An old unmarried woman is unknown, nor are old lachelors often met with. The advantages attending the marricel state, according to Chinese institutions and notions, liecp up the population to a highpressure state; lat there are fow fumilies with more than four or five children. The disproportion lectween sons and ratohters camnot be aseribed to natural causes, and it is arlmitter that femule infunticide prevails lere as in other parts of China. The females, 
notwithstanding their cramped feet, work very hard both at lome and in the ficlds; but the men never oblige them to plough or perform the labour of cattle, as is the case in some parts of China.

A wedding is colebrated by all with more expense and display than any other erent of life. The parent of the brite receires a certain sum of money, as soon as they agree to marry their daughter, but they at the same time furnish her trousseau. The men are generally too poor to hare more than one wife, and the conjugal tic is pretty lasting. The wires are remarkable for their quarrelsome dispositions and passionate bchaviour when once roused.

They do not attend much at home to the education of their children, beyond teaching the daughters to sew. The sons at about six rears of age go to school if the parent can afford it, and pay perhaps the value of two or three dollars ammally to the teacher. In those establishments of course none but the most elementary knowledge is taught. The boys learn to read the sacred books of Confucius, and to write a legible hand, and leare school as early as trelve or fourtecn years of age. Those who intend to repair to the public examinations, and choose a higher walk of life, continue longer at school and subsequently read at home. When we first took possession of the island, there were two colleges wherein the youth of maturer age studied to become graduates, but the sum total of the learning, as usual, did not go berond explaining the classical books (those of Confucius), and miting essays. As 
some thirty were adranced every year to the grade of Sew-tsae (bachelor), there was a great deal of emulation among them. A few of the elder having obtained the rank of heu-jin (licentiate), and one of them eren promoted to a macristracy in Honan prorince, literature was held in some esteem and reputation on the island. Nevertheless, the mass of the population, in consequence of their extreme poverty, can neither read nor wite, and this is the more remarkable, as in most parts of China few of the male sex can be found entirely devoid. of an elementary education.

The character of the population eomprises the usual mixture of good and bad. It has been shown that they are a hardworking and patient race, and easily guided when once their confidence has been gained; but, like their countrymen on the mainland, they are commonly lying, thievish, and faithless. The most solemm asseverations amount to nothing, and nobody considers himself obliged to perform promises unless bound by something more cogent than a mere sense of duty. They are fond of litigation, easily awed into obedience, orderly and quict; but of course ignorant and narrowminded, and incapalule of comprehending anything beyond the range of their very limited experience. We have seen that they are patterus of contentment, checrful bearing, and patienco under difficulties; but in their social dealiness they are knaves, and, whocver has the power and opportunity to do it, oppresses and takes adrantage of his ucighlom. During one four gears' tenure of the islind as eonquerors, martial law 
found them very quiet and orderly suljects, and had little or nothing to do the whole time, as Brigadier Campleil reported.

Such reliwion as they possess consists in the forms and rites of the grossest idolatry. In the town, and in the numerous rallers, there are abundance of temples (called by our people Jos-houses) built by subscription, on nearly the same models, according to their respective sizes. These serre for the raried, and somewhat inconsistent, purposes of schools, taverns, gambling houses, and theatres. They are generally built, in the country, at some romantic or picturesque spot, in some hilly pass, or some wooded nook, and derive more of their attractions from this than from their architecture. In them are to be found a few clay images of gods or deified heroes rudely cxecuted, and in the larger ones is a priest who subsists on alms, and rather degrades the ecclesiastical character by acting at once as tarem-keeper and waiter to the travellers or visitors. Both temples and priests belong to the Buddhist religion, and the hierophants are of the lowest order of uneducated people, satisfied with a bare subsistence. All their business is to burn incense before the images, keep the lamps trimmed, and on festive occasions light up the building; or, at other times, they are working in the field; for to some of the temples a piece of land is attached as an endowment. They exercise no influence rpon the minds of the people, but are generally treated with contempt.

Altogrether different from these are the preachers of 
the Taou sect, or Rationalists, ${ }^{1}$ of whom there are about thirty in the town of Tinghae, and some in tho country. They read sermons at burials, marriages, times of sickness, and other domestic occasions, and also exercise the office of exorcists, the Chinese being especially afraid of ghosts. The punishment of hanging was viewed by the natives at Hongkong as a comparatirely indifferent matter, as long as the bodies were delivered to the relatives to be interred with the usual ceremonies; but when the order was given that they should be buried within the precincts of the gaol, the terrors of both hanging and imprisonment were mucb increased, and with salutary efiect, as was intended.

The priests of Taou wear no distinguishing badge, nor do they maintain celibacy, but lead a secular life among the people at large. In their professional capacity they recite in a drawling tone discourses which only the initiated can understand, and will go on for five days for a single dollar. The common people look upon them more as sorcerers than teachers.

In many houses there is a domestic shrine, where the inmates licht a lamp and lurn incense; but, subsequent to the oceupation of the island by the English, idolatry of all kinds very much declined. Their gods had perhaps fullen into discredit since the untoward results of the war. Occasionally a procession michlit be seen winding its way throunl the streets; lut only the rablle were to be foumd in its train. The mass of the

Described in "The Chiuese," vol. ii. 1. 70. 
people really live withont religion, totally unmindful of anything but the supply of their physical wants. The only Sablath in the whole twelve months is the New Year; all the rest is a round of unceasing daily toil, to those who are condemned to Iabour. A survey of China afforts the best practical argument in farour of the Sabbatical institution, and of the blessings it confers on mankind; when clear of that fanatical excess, Pharisaical rather than Christian, which was anthoritatirely condemned by Christ himself.

The oceupation of nineteen in every twenty of the inhabitants is agriculture. A large portion of the soil is held by families, not individually, but according to the Chinese rule of domestic clubbing. On letting Iands to the cultivators, a stipulation is made for one Lalf of the produce in kind, and, when the harrest arrices, the corn, on being beaten out, is put into scales, and this equally divided. The cultivator pays the tas to Gorernment, according to the nature of the land, at so much per mow, a space that will produce at the most eight peculs of paddy, or rice in the husk. The farmer must provide all the means of cultivation, and holds his lease, as temant at will, entirely at the pleasure of the owner, who seldom lets abore ten mows to one farmer, generally only five, with the produce of which the latter must manage to subsist.

Their agricultural implements are of the most simple description. The ploughshare is a piece of cast iron; the spikes of the harrow consist of linives which cut sideways. After the second rice harvest is off, they 
plough the fields, allowing them either to lie in large clods, or sowing a species of clover, which is used, not for feeding cattle, but as a manure. This is confirmed by the observation of Mr. Fortune, who says :-

" $\Lambda$ fter the last crnp of rice has been gathered in, the gronnd is immediately ploughed up, and prepared to receipe certain harly greesu crons, such as elover, the oil plant, and other varieties of the cabbage tribe. The trefoil, or clover, is sown on rildges, to keep it athore the level of the water, which often corers the vallers during the wister months. When I first went to Chusan, amd san this plaut cultivited so extensively in the fields, I was at a loss to know the use to which it was applied, for the Chinese have few cattle to feed, and these aro easily supplied from the roadsiles and uncultivater larts of the hills. On inquiry, I found that this crop was coltivated almost exclusively fur manure. The large fresh laves of the trefoil are also picked and uscil as a reretable by the natives."

Their main reliance, however, is on the most disagreeable, though perhaps the most fertile, manure so universal in Clina. They leep it in small waterproof tanks, and promote fermentation by throwiug sulsstances into it. They are in this respect extremely filthy, and with senses more olstuse than might be readily imagined. For peas, and some other regetables of the pulse tribe, they use dry ashes at manure, throwing it into the drill prepared for the seed, and thus manuring the plant rather than the ground. The discovery of Liebig, that beans and peas contain riscime, a sulstance identical with the curd of milk, has beon familiar to the Chinese for

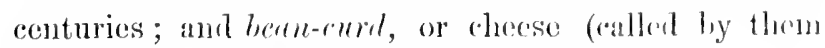
Tow-foo), is commonly lawked about the strects.

They transplant almost every article from a secd hin, 
no matter whether green regetable, grain, or pulse, and assimilate the cultivation of nearly evorything to that of rice. In the case of the sweet potato (a conrolrulus), they cut off the spronts and plant them, after having dug ${ }^{\prime}{ }^{3}$ the previous crop. These sprouts are an article of trade; and, to improre the quality of the potato, people from great distances on the coast of China come orer to Chusan and plant whole tracts of hills, with a certain stipulation regarding the prociuce.

Chusan has but few manufactures. Some weavers make up coarse stuffs of cotton from yarn which has been spun by the cottagers; but the home-made article is not sufficient to clothe more than a portion of the population. There are some forges constantly at worls in Seaou-sha, near Ting-hae on the N., for proriding agricultural implements; and the salt works on the coast make up the total of industry apart from agriculture. Within the town of Ting-hae, during our occupation, a consiterable business was carried on in the carving and ramishing work, which exists in such perfection on the opposite coast of Ningpo. Nothing can exceed the durability and neatness of furmiture prepared in this manner. The greatest care is bestorred on bedsteads, or rather little tabernacles, which constitute both a bed and dressing room within themselves, and on which a profusion of carring and inlay-work is larished. One of these obtained a prize at our Great Exhibition.

Previous to our occupation of the island, a great number of junks which traded between the N. and S. 
touched at Chusan, anchoring in the harbour of Tingbae, where the suburbs formed a depott for merehandise. The presenec of our shipping seemed to discourage this resort; but Sinkeamun, to the eastward, continued to be a place of rendezvous for a great number of ressels, chiefly fishing crift, which r'unged at large among the group of islands, and along the embouchure of the Keang, mamned principally by Fokien sailors. These adventures are partly carrich on with the capital of the island; and some Folien firms, who traded in company with Chusan merchants, were establishcd in Ting-hae. Thus, the most necessary article in China next to rice, that is, fish, was provided for the arljacent main from the Chusan group, whose shallow seas and landlocked roatsteals are musually faromable to fishing. The other prineipal exports were coarse black teal, eotton, regctable tallow, sweet potitoes, and some wheat. 'The litrere junks were driven away by our capture of the istimd, lut the smaller clatt semed to inerease. They came from Wunchow, Tilceliow, Shihpoo, Seang-shnu, Ninglo, Shaouhing, Hainghow, and Chapoo, bringing the produce of their respective districts, and principally rice, as well ats Siven silver; in return for which they hought our cotton mannfiustures, epium, a few woollens, and some Stratits' proluce.

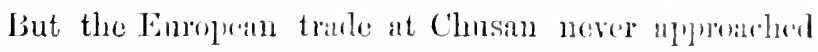
the anticipations of matny simenine speculaters. Tho

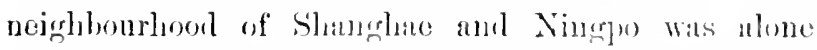
enough to attract and ongross the main part at those large marts, especially the former. (mupreded, low- 
ecer, with what existed previous to our arrival, the trade was actire, and many of the native traders of Tinghae hecame comparatively opulent; a result which they could rery little have anticipated, from what they must have been accustomed originally to regard as a great calamity.

Should Japan become effectircly open to European trade, Chusan, from its vicinity, must occupy a still more important position than it has erer done yet. The new whaling trade, established by the Americans in the adjacent scas, would find it a most convenient spot for refitting and supplies, for which they now resort to Hongkong. Nothing more would be then required to complete its prosperity but an increased cultivation of tea and silk, for both which products it possesses the exact geographical position and climate which are found most farourable on the opposite coast of China.

Prerions to our occupation, Chusan and all the smaller islands of the group constituted a district under the jurisdiction of Ningpo. The principal ciril authority was a magistrate of the rank of Hien, with two subordinates at Tinghae, and sereral others on the other islands under his charge. He transmitted about 10,000 tales and 30,580 shih of rice annually to the gorermment on the main.

At the head of the military establishment there was an admiral, with about 20 to 30 war-junks, and a nominal force of 5,000 to 6,000 men. A great part of these were mere men of straw, whose pay and allow- 
ances were drawn, in Chinese fashion, ly the mandarins. It was seldom that a tenth of the number could he mustered, and it was said that at our tirst attack in 1840 no more than 500 men were fortheoming. Tpon the temporary eracuation in 1841 the importance of the position was fully perceived by the Chinese Gorermment. and three generals, with about 10,000 men, were sent orer expressly, at the same time that a militia was raised on the spot. On the sccond capture in 1841 these three generals all fell, one in action, and the two others by their own hands. After the conclusion of peace the Chinese Government endearonred to retain some anthority over the island, notwithstanding our occupation by treaty, and an oflicer wats stationed at Tackesturn with this view. But his improper interference becane soon checked by the adoption of summaly measures, and the inhalitants were therely tanght that no divided sway woild be permitted during onr oecen altion. When britisle rule becune extrneded over the island, it wats the first olject of om oflicers to put at stop to the violenees and aisonder which land prevatiled during the war. Native constalles were estallishled in all the valleys, and these leing erencrally men of substance and influence, and sapporterl by our antlupitics, suceceded in restoring onder and ensuring the serourity of preson and property. Tllere was, lesides, a small and eftective police, which, being hatedied on oceasion by

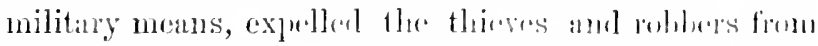

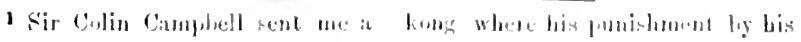

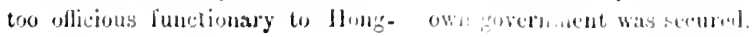


the island. In a short time crime decreased; nothing was lost that was not in time restored, or its cquivalent recorered. The exemption from all taxes during our tenure of the island tended of course to conciliate the good-will of the people; and upon its eracuation in 1816 the Emperor's Gorernment did not deem it prudent to alienate the Chusanites by demanding past arrears from them. Their experience of British rule under circumstances of military conquest can hardly have failed to convey a favourable impression; and the stimulus giren to the trade and industry of the island rendered the war, in its ultimate results, a benefit rather than an infliction to the inhabitants themselves.

Cluusan has since, for the third time, been in our occupation during the last Chinese war. 


\section{VIII.}

\section{AXALISIS OF I HORK ON HCSBANDRY IXD BOTLNY.}

(Prescuted to the Horticultural Socity with the original work.)

Derixg the four years passed by me in China, as Governor of Hongliong, I had freepent communications with an accomplished Italian, Monsignon. Il Conte di Besi, Bishop in protibus infildium. His long residence in the country (I had linown him there in 1S34), and his knowledge of the lingnage, joined to the new facilitios and immunities afforded by our treaties, hat enabled him to procure valuable Clinese books, anong wheh was a work which he was good enomgle to present to mysclf. It relates to the whole system of national hushandry, and treats at the same time largely of botany, being entitled Noony-Chin!! T's'nenshoo, literally the Iie Iiustice liber completissimus. In a Chinese sense the title is certainly not misapplied.

Subsequent leisure has, conalded me to examine it with srme attention; and as the methodical armangement of the work, torgether with the incillental notices, appeared to be sufliciently illustration of the state of Chinese knowledge on an inportant sulpject, it ocenomel 
to me that a short analytical summary of the whole might be considered within the scope of the objects pursucd by the Horticultural Society.

The mork is divided into sixty sections, and contained in twenty-four of those brochares which constitute the form of all Chinese books. A corering of handsome green silk distinguishes this book from ordinary ones, and the printing and paper are of the best rescription. Some humlreds of colomed roodcuts illustrate the various objects described in the work.

Sect. I.-III. The first three sections treat of the nrigin and early history of husbandry, commencing with what is to be found in classical writers, and then procecting to cite generally what has been said later on the subject. "Men," it is observed, "lived entirely on flesh until the time of Shin-Noong, "the divine linsbandman,' who taught them to study the seasons and cultivate the earth." This plainly refers to the pastoral state as preceling the agricultural, and the firct lessons of the Chinese, as of all other early nations, consisted of what Tirgil calls

"Arrorum cultus, et sidera celi."

The third section records all that the different drmasties of sorereigns have instituted as regulations and customs to give importance and encouragement to linsbandry. In my work on China I had occasion to state that agriculture has always been called the "root," and mannfactures and trade only the -branches."

sect. IT., T. These two sections are on the con- 
struction and regulation of fields and cultirated lands. They are ranked in the threefold order of-1. Riceficlds, or those artificially levelled or flooded, and cilled Tien; 2. Those destined to the ordinary, natural, or dry cultiration, called Te; 3 . The hills, or more barren and waste lands, called Shom. These thrce constituted the divisions of Chusan during our oceupation, ${ }^{1}$ and they pay dues to gorernment accordingly, in a descending scale. The terrace cultivation in steps is called Te-tien, or "Ladder-fields."

So generally have the Chinese alhered to the decimal scale, on account of its obvious adrantiges, that their land measurements are squares of ten. Thus a hundred square poo make a more, or what has been called a Chinese acre; a hundred mow malie a fin. The original or theoretical divisions of land were in the style of a chess-boarl, which of course usually becomes impossible in practice.

Sect. VI.-XI. The next six sections are entitled the "Business of Husbandry." The sixtl and seventh relate to the management of farms, ploughing, and the use of manures. It is inculcated as a maxim in firming, "Better a little land and good than much and bad." The eighth and ninth scetions are on the breaking up and reclaiming of waste lands. 'The government, as an cncouracement to the cultivation of wastes and the production of food for the people, allows any unreclaimed lands to become the property of

1 Chusan in Jitish Occulation, page 131. 
lim who first brings them into tilth, and levies no taxes until such time as the produce yields a surplus. The tenth and cleventh scctions treat of the four seasons and their respective productions. The twelve lumations of the Clinese ycar are reviewed in detail. The rarious natural phenomena of each period, with the plants and animals which distinguish each, are cnumerated, and there is a complete collection of prognostics. The suljects are exactly those of the Phenomenu and Inosemeic of the Greek poet Aratus. In the tenth section is giren a curious diagram, consisting of concentric circles, after the fashion of those which surround the Chinese compass. Near the centre are the seasons, months, \&c., and radiating from each of these are the natural phenomena of each period. In the outer or largest circle of all are the labours to be performed, and the products to be expected, under every season. It is in fact, a rery comprehensive synopsis of " Trorks and Days."

Sect. XII.-XX. Considering the important part which water performs in Chinese husbandry, it is not surprising to find nine scctions deroted to the "Profit (or use) of Water." After some Tsoong Lun, or "general observations," the work proceeds to notice the modes of irrigation in various parts of the empire; but as the eastern and southern prorinces are incontestably superior in their natural adrantages to the western and northern (which are either mountainous or cold), so three sections are giren to the east and south and only one to the west and north. 
The serenteenth section treats of the construction and management of dams and sluices, and the various modes of raising water to a higher level. Colonred moodcuts give very clear representations of the wooten chain-pump, the (so-called) Persian wheel observed by our embassies in the interior, and other contrivanees for irrigating lands lying abore the level of the water required. This is very essential in rice eultivation, and the Chinese effect their olject, as usual, with great ingenuity and suceess.

The eighteenth section treats of Chinese waterwheels of various descriptions, which are illustrated by coloured wooleuts; and the nineteenth and twentieth sections grive some aceount of the water machinery of the "great west," meaning some of the practical applications of hydrostatics and hydraulies in Europe. This must have been collated from treatises in Chinese composed by the Jesuit missionaries. Coloured diagrams are interspersed, explaining the principles of lifting and forcing pumps (the latter with double alternating pistons and no air-chamber), and other European contrivanees. They commonly apply the principle of the forcingpump in their fire-engines, which are very efficiently constructed. The Chinese are shrewd enough to perecire and arlopt what is really advantageous in use, thourh it may be forcign, and this part of the work contains the very undenialble remark that, "without, the machinery for water, you eamnot have the profits of water."

Sect. XXI.-XXIV. 'These four scetions are deroted 
to the description and representation of Noong Kee, "The Tools or Jmplements of Husbaniry." Here the coloured wookents come in with good effect, and are highly illustrative of about one hundred and twenty different implements, the use of most of which is suffeiently obrious without the printed description. They comprise varieties of ploughs, harrows (square and diagonal), scarifiers, bush-hurdles (some loaded with stones), rollers of different linds for smoothing or dibbling the ground, hoes, spades, shovels, rakes, breast-ploughs, sickles, bill-hooks, choppers, slicers, lamboo stages for drying corn, instruments for separating the corn from the husk, mills mored by two mules, baskets, tubs, and vessels of many sorts, and winnowing machines. Of the last I have already remarked in my work on China, "They have a wiunowing machine exactly like ours, and there seems to be the best evidence for the fact that we borrowed this useful invention from them. A model was carried from China to Holland, and from Holland the first specimen reached Leith."

Sect. XXT.-XXX. Six sections are deroted to all those regetable productions which are the suljects of planting or cultivation. It may be remarked, incidentally, that the importance of eight of these is indicated by their names constituting eight out of the 214 roots of which the whole written language of China is compounded, riz., Pice, Bamboo, Wheat,

1 There is no representation of a flail. 
Millet, Bean, Onion, Hemp, and Cucurbitaceous plints. They were, in fact, the original materials of food, lodging, and elothing, as derived from the eirth.

The first two of the abore six sections treat of the principal sorts of grain and pulse constitnting the materials of food. The third comprises the different species of encurbitaceous plants, of which the Chinese possess a great variety and make much nse. The fourth is on various culininy regetables, chiefly of the onion and leek tribes. The list two enmerate and describe the principal fruits of China, as the lecehee, the longan, the mprica described by $\mathrm{Mr}$. Fortune at Chusan, the gripe (little cultivated in comparison with Europe), the great variety of oranges, citrons, les. Se. I had occasion in another place to notice thit the Chinese do not cultivate their firuits with quite the eare and skill that they bestow on their flowers; and the practice of planting their fruit trees on the banks of streams and camals, though it las been found furouralle to the trees, renders the fruit the object of depredation, and cususes its being gathered immature.

Sect. XXXI.-XXXIV. These four sections are deroted to T'sin Sim!- "Silliworms and Mullyerry-trees" - that is, the rearing of the silkworm, and the coltivattion of the mulleary for that purpose. 'The thing-first

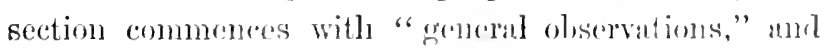

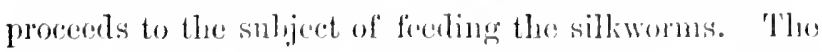
thirty-second relutes antirely to the plinting and cultivation of the mulbery-tree. The next two sees- 
tions are copionsly illustrated with woodeuts, in explanation of the management of the silkworm by women, from the egg to the spinning of the cocoon by the worm, and then onward to reeling off the silk, and erery other successire step to the final process of wearing.

Sect. XXXY.-XXXYI. After silk come the tro cognate suljects of cotton and hemp, the first of which is treated in the thirty-fifth, and the second in the thirty-sixth section. Numerous moodents represent the various processes of reeling and rearing these two substances.

Sect. XXXTII.-XL. These four sections are deroted to the subject of Choong Chě-" Sowing and Planting." First come general observations, which occupy the thirty-serenth section. A great number of useful trees, among others the rarnish or lacquer tree, are discussed in the thirty-eighth chapter; while the bamboo and the tea-plant occupy, par excellence, nearly the whole of the thirty-ninth. The fortieth section is devoted to the consideration of nineteen different rarieties of useful trees and plants.

Sect. XLI. This section treats of domestic animals, cither edible themselves or useful in proriding or preserring fool. They are in the following order:Horses, mules, oxen, sheep and goats, pigs, logs, cats, geese, ducks, forls, pond-fish, and lastly bees. The Chinese, lilie Tirgil, call the queen bee the ling.

Sect. XLII. The whole of the forty-second section is 
composed of a large collection of useful receipts, principally for the preparation of articles of food.

Sect. XLIII.-XLV. The remaining portion of this work is the most remarkable of all. I have endearomred, in my work on China, to explain the causes which (grounded on the encouragements to orer-population) tend to make the country liable to frequent visitations of dearth and famine. For these reasons, there is no nation, perhaps, in which so much attention has been directed to extraordinary provisions against famine. To this may probably be attributed the unlimited range of the Chinese kitchen and bill of fare, as well in the regetable world as the animal. I may quote an example from the description of a dimmer at Chusan :"Another strange ragont proved to be the flowers of the eommon China (or montlly) rose, dressed whole. Here the mixture of salt, sour, and other indescribable flarours forluade a repetition." There are few instances in which we dress the flowers of plants. For one, at least, there is the authority of the inveterate Londoner who saicl, "there was no garden like Covent Garden, and no flower like a cauliflower." Articholies are another example of eating a portion of the immature flower.

The three sections, from forty-three to forty-five, are deroted to tho history of pullic provisions against dearth. In the last is an enmmeration of 41.1 plants described and fignrer in the concluding volmmes of this work, of which 188 are taken from the stantiud Chinese 
herbal, ealled Pun-tsuou, and 276 have been alded. They are classified as follows:-

$$
\begin{aligned}
& \text { Tsanu-Iferbaccous }{ }^{1} \text {. . . . . } 245 \\
& \text { Mrül-Wooly . . . . So } \\
& \text { He Kŭh-Grains and Pulse . . . } 20 \\
& \text { Kuro-Fruits . . . . . } 23 \\
& \text { Tsuc-Culinary Herbs . . . . } 46 \\
& 414
\end{aligned}
$$

A further classification of the same is given, as muder :-

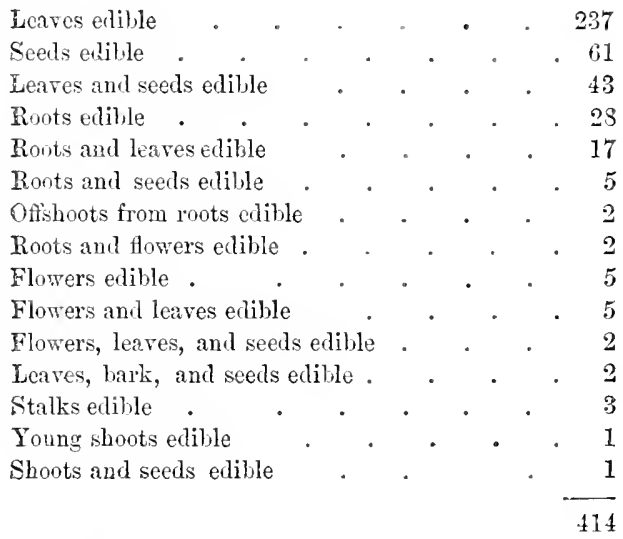

Sect. XLTI.-LIX. These fourteen sections are styled the "Provisional Herbal against Dearth," being the history of all the plants above classified, and the modes of preparing them as food. The description and coloured representation of each plant oceupy two con-

1 This term is extended sometimes to soft-wooded or pithy plants, as the fig and the plantain, the last being really lerbaceous. 
tiguous pages, and are easily found. The contents of the sections are as follows:-

Sections.

XLVI.-L. Herbaceous plants, leaves edille . . . 159

LI.,$\quad$, roots,$\quad$. . 2:

LII. " " " . 20

, " " " leares and seets edille . 12

" , " , roots and leares , , 23

, , " stalks , . . 3

, , , shoots and seeds , . 1

LIV. Woody plants, leares edible . . . . 41

LT. , " seeds (or fruit) edible . . 20

LVI. ", ,, leare's and seeds ," . . 8

, , , flowers , . . . 5

", ," flowers and leares celible . . 1

", ", ", thwers, leaves, and sects ellihle 2

" , ", leares, bark, auml seeds ., . 2

., , , offshorts from roots , , 1

LVII. Grain and Pulse, seeds ellile . . . 20

LVIII. Fruiting plants, fruit colille . . . 11

$, \quad, \quad$ leaves and fruit edible . . 5

" " " $"$ roots $\quad$. 2

, , ,, roots and fruit , . . . 2

,C Culinary Ilants, leaves edible . . . 14

LIX. " " " , , . . . 19

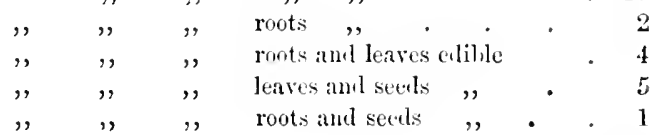

1]10

The albove list is, for some reason or other, short of the preceding summary ly four.

Sect. LX. This conclurles the work, with drawings and descriptions of sixty-three wild plants, colible in calse of fimine.

As to the style of deseription, the following aceomt

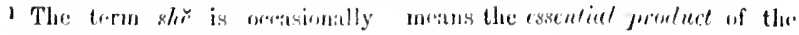
alpliesl to cither seed or fruit. lt plimt. 
$17 \pm$ ANALYSIS OF A WORK ON HUSBAEDRY AND BOTANY.

of the native Clinese fig (Sect. LY.) is a specimen of the way in which each pictured plant is described. From my own experience, the native fig of China is rery poor, and hardly advanced beyond the wild state. It would be a real benefit to send some of our European figs to Hongkong.

"The flowerless fricit grows in the hills and wilds. At present it is also planted in gardens. The leaves somewhat like those of the rine, but larger, stiffer, and thicker; civicled into three lobes. The fruit grows at the junction of the leaf with the stalk. It is at first green and small; when ripe, of the shape of a pear and of a purple colour; taste sweet. The fruit may be gathered and eaten."

The drawings in this work, of some four hundred and sixty plants, however inferior to our own in execution, might rery well serve, in combination with the appended names and descriptions, to procure specimens of the plants, of which many must be new. The localities are often, and indeed generally, mentioned. Portions of the work might be adrantageously translated in cletail; but two circumstances are essential: the translator must have leisure for the task, and he must be resident in China, as many points mould require elucidation on the spot. 


\section{IX.}

\section{TALLEY OF THE KEANG}

TO THE PORT OF IIATHOW.

(From the Joumal of the Royal Lnital Sorvice Institution.)

The Keang, or Great River of China, or the Yang-tsze (Son of the Sea), has been laid open by the treaty of Tien-tsin up to the central mart of ILankow, a distance of more than 500 miles from its mouth below Nanking. Haring myself journeyed along 300 miles of that distance, from the extremity of the Grand Canal to the Poyang Lake, I purpose to state the results of my own observations to that extent, and to supply the rest from the experience of other's. The fruits of Lord Elgin's adventurous and most interesting expedition may be introduced by a condensed summary of what hiss been known before, and followed ly a comparison lectween the former and present states of the country (before and since the devastations of the rebels), as the ground of our just anticipations for the future.

The whole tract in question lies, witl little exception, between thirty and thirty-two degrees of north latiturle, the faroured climate of tea and silk, our principal imports, and including some of the finest portions of China. Commencingr by the mouth or alclat of the 
river, we have the long allurial island of Tsoong-ming, abont thirty miles in length, and called from its shape and position Keang-she, the "tongne of the river." A small party landed here during our first war and lost an officer, whence that spot at the rest end was called Harrey Point. Its principal town, Tsoong-ming-Hien, on the soutl coast, is only a tomn of the third class. The canals with which the island abounds have high embankments to preserve the country from floods, especially dangerous from the low, flat, and allurial formation of the land. The dense population has resulted as the effect of Chinese industry exerted on a naturally fertile soil. The portion least cultivated is the north side, abounding in those coarse high reeds which are found on the low shores or islands of the rirer higher up, and which serve, in combination with mud, to form embankments and even dwellings, as well as occasionally answering the purposes of fuel. A portion of the soil in the northern part is so saturated with sea salt as to form a fund for the supply of the whole island, with a large surplus for the main land itself. ${ }^{1}$ The southern portion is the most fertile and cultirated division of the island, producing rice, wheat, barley, and millet.

1 This article is so superabundant as to render its importation from abroad a rather profitless speculation. It was a part of my business in China to decile against its importation, in accordance with the fiscal regulations of the gorern- ment, with whom it is a rery im. portant source of revenue; and by the trade regulations appended to Lord Elgin's recent treaty at Tientsin, this decision has been confirmed, the article of salt being expressly excluded. 
From the western extremity of Tsoong-ming to Chinkeang on the Grand Canal, which is the first point of mnch interest on the river, the total distance, with windings, is about 125 miles. That so long a tract should be comparatively destitute of large towns ${ }^{1}$ is explained by the fact that the government, aware of the accessibility of Nanking and the Grand Canal from the sea, has always discouraged the navigation below Chinkeang, the canal itself supplying an inland transit independent of the sea-coast. This portion of the river was a profound mystery until Armiral Sir William Parker in 1842 conducted seventy men-of-war or transports to Nanking without the loss of a vessel, where no Emopean lieel late ever plonghed before. This, and the late expedition of fire war steimers all the way to Hankow, in spite of diffienties generally deemed insurmomtalle, are exploits of which our nary may justly be proud. I have known many instances in the fur east where they latse hat the good fortume to succour foreign ships of war in trouble ; and I cammot call to mind any oceasion (of a merely natutical nature) on which they have had to claim foregn aid themselves.

It is at Chin-keang that my own aequaintance with the ereat river besins, and continues to the Poymug Jakke, about 150 miles short of our treaty limit at Hankow. Jommeying in the boats of the conntry, the

1 The rhicf towns whinh suecend corle other an the worth lank are

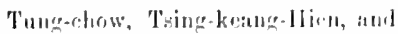
Tac-yu-Ilien; on the south linuk are Troo-paton-Hich and Yeh-shinIling, -all of them towns of the secousl and third order. 
difficulties of the passage to a large squadron of Chinese ressels, against the stream and a contrary wind, occupied no less a time than from the 19th of October to the 14th of November, or little more than ten miles a day, leaving abundance of time for excursions and observation. It conveys some idea of the breadtl of the river (when full from two to five miles in breadth) when I state that it frequently afforded a tolerable horizon for ascertaining the latitude.

The neighbourhood of Nanking has become so comparatively familiar to us that we may pass on at once to a higher and less known point, which we reached on the 29th October, namely, Se-leang-Shan, the "Western Pillar Hill," a remarkable high rock, which, with the "Eastern Pillar Hill" on the opposite shore, forms the Gades of the Keang, about thirty-five miles above Nanking. From the top of the western rock, a height of 500 feet, we observed the broad channel of the river, as it flows between two lines of mountains to the sea. This is a remarkable spot among the Chinese themselves (in peaceable times); and the well-built town at the foot of the rock seemed to owe its existence to the influx of visitors. On the 30th October the strength of the stream and the want of wind obliged us to stop at Wu-1nu, a very considerable town about ten miles above the "Pillar Rocks," and dependent upon Taeping. In proof that the technical classification of Chinese towns does not always indicate their real size and importance, this appeared to be superior to many of their first-class cities; and it was to the great inland com- 
merce carried on by this town that such musual wealth and prosperity were to be referred. Wo here tirst observed bales of eloth with the English mark upon them, about 600 miles from Canton, inlind.

Quittingr Wu-lun on the 31st October, we started with a north-west wind, and, our course here being sometimes due south, we made more progress tham nsual, accomplishing a hundred lees, or thirty miles, by the time the boats reached the mouth of a tributary river named Teih-keony on the right bank, in which wo anchored, near a small town built at the foot of some low lills. The Emperor's desire to get rid of us ly the shortest ronte was the forturate occasion of our thus narigating the Keang hetween the Grand Cimal ant the Porang Lake, instem of following the beaton tratck of low marshes alomg the remainder of the canil. After travelling throngh the swamps of shantmugr atrel the north of Kamernin, we were now in a combtry that yiells to none in the whole world, and is equallunt by very few. It was justly remarlied by the late sir Henry Ellis, one of one party up the liemen. "Howeres. alswret the pretensions of the Enmperor of ('hinn to universal supermacy, it is impossible to travel thromeng his dominions withont fecling that he has the tinest comtry within an inperial ring-fence in the worlel." After the lapse of abent a fortnight we were, owing to contrary winds and the timidity of our boatmen, net atvansed one hall of the way to the lake; lut this delay only afforded the more time for olsorrmtion and 
inland excursions, which met with no opposition from our conductors.

On the 1st Norember, we adranced only twelve miles, to Tsing-lica-chin, on an island which divides the stream of the Keang, and above which the river spreads to a breadth of nearly five miles, after describing what appeared to us a considerable portion of a circle round two islants. On the 2nd, as early as nine o'clock, we found the whole squatron of boats anchored at the considerable town of Tung-ling II 'n ${ }^{1}$ on the right bank, eighteen miles from Teilh-keang. Thinking we were to stop for the day, some of us set ont as usual on a ramble througl the town into the country beyond, hut in the conrse of an hour the wind became fair and the boats prepared to sail. We had extended our excursion to abont two hours, when some Clinese came hallooing and announcing the departure of the fieet, and we did not conclude our chase of the boats on their way up, until fonr hours after quitting them.

On the morning of the 3rd Norember we were anchored at a town called Tilumg Chin, on the right hank, and opposite to those long islands by which the Keang is so often divided. We were detained here by contrary winds for no less than five days, which were spent in exploring those beautiful hills at the foot of which the town lies. Our excursions extended to cir-

1 The name denotes "copper of a valuable green stone found here mountains," and Du Halde speaks probably malachite, or copper ore. 
cuits of fiftcen and sixtecn miles, when we often came across tea plantations, thongh here less frequent than in the south-east parts of herng-men, and in Cher-liren!! and Foliente.

On the morning of the 7 th Norember it blew strongr from the north-east, and we made one of our best day's jommeys, arriving in the afternoon at Wooshatkea, or "Black Sand Fork," liea meaning one of those numerous points where the Keang forks ont into two branches to compass an island in the midhle. As we were albont to enter again on the main stream, om condnetors thonght it prutent to remain mith the wind moderated. Nothing was more surprising than the ditherence between the Chinese sailors of Canton and theil " lonershore" brethren of the Kcang. The boats were almost as different as the loatmen; lin, while the Canton boats are strongly lonilt and calnalle of buffeting with the waves, these great stmitre boxes, damped with irom at the joininess, seemed really to justify the approhen-

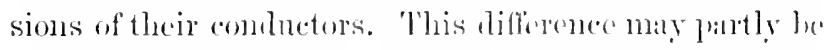
ascriber to the hathit of oreasionally ancomtering the sea near Canton, and partly to the long experienes and example of Euloperans at that jliner.

On our way to the present ancheratere we passed the

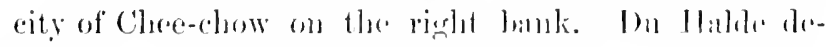
seriles this as latring six dependlont towns, and, thomgh

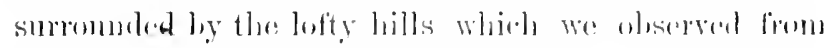

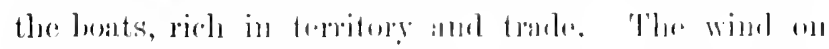

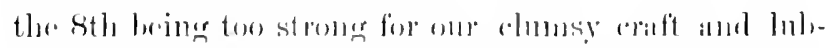

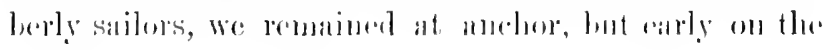


morning of the 9th started with a fair breeze, and after traversing about one hundred lees, or thirty miles, anchored on the further or western side of Ganking, an important first-class city. Du Halde describes the position of this large town as very adrantageous, and states that a Tartar garrison was kept there for the command of the Keang and the neighbouring lake. He must have passed this on approaching the east side of the city, where 500 men in line made a good appearance. Our examination of the interior and suburbs conveyed a favourable impression of the place, where we found very good porcelain shops, indicating our approach to the neighbourhood of King-tih-chin, the chief place of its production.

We left Ganking at an early hour on the morning of the 10th November, and, after the best day's run since entering China, viz., 125 lees, or nearly forty miles, reached a place called Hwa-yuen Chin, or the "Flowergarden Station," abont five miles short of Wangshan Hien, on the left bank. On our way here, we passed Tung-lew Hien, on the right bank, a walled city of the third class, but containing within its extensive enceinte fewer streets than dwellings and gardens. The most populous part of the place was on the outsicle of the walls, between them and the river. The houses in this part of the comnty were whiterashed, which gave them an European look. Parts of the river, even as high as this, appeared not less than three miles across, and huge porpoises were rolling along near our boats as they do at sea. 
After being detained at Hwa-yuen Chin for a whole day, we sailed on the 12th Norember, and soon came to a part of the river where it is again divided by a long island into two streams, and proceeding along the sonth or right hank, we passed Ma-tung-shang, "Stirrup-iron Hiil," a curions bluff point; and towards evening ap. proached a rery remarkable insulated rock, rising precipitously from the stream to the lieight of 250 feet. This (with another larger one at the entrance of the Poyang Lake) is celebrated in China by the name of Seao-koo-shan, the "Little Solitary" or "Orphan Rock." It appeared inaccessible on all points, except one, and here the Buddhist priests had contrived to ereet some of their temples on terraces, rising one abore the other. But the most remarkallle feature was the countless swarm of pelicans, or fishing cormorants, which darkened the face of the rock by their numbers.

We had now entered the limits of the Keangse prorince, and the first walled town we passed, ly name Peng-tse Hien, was, in point of position, the most remarkalble we had seen. It lay on the right lank, nestled in a romantic valley, or rather amphitheatre, formed by the lofty hills aromd, but open to the river. Among native drawings of remarkable places I possess one of this town, as well as of the "Orphan liock" - both of them especially noticed in Lord Elgin's expedition.

The weather became thick and boisterons, hut we proceded, and our boat with some difficnlty renched Kin-kantr-lenon, onr destined resting-plane, beingr a rillage of small note at the month of a creck on the 
north or left bank of the river. We passed the 13th also at this anchorace, which the Chinese itinerary stated to be about sixty lecs, or some twenty miles, from the mouth of the Poyang Lake. We became naturally anxious to inspect this famous inland sea, which, howerer, though about seventy miles long, is only the second of the empire in size, and yields greatly to the Tong-ting Lake, also fed by the Keang, but considerably above Hankow.

We set sail early on the 14th Norember towards the Poyang. On the hold and hilly shore to our left (the right bank) we passed Hu-kow, at the "Lake's Nonth," as the name implies. Here, after little less than a montlis protracted journey orer a distance, by the Chinese itinerary, of 950 lees, and by our own calculation 280 miles, from the canal, we quitted the magnificent Keang to cross the lake on our way towards the south, already 400 miles from its month, but yet 2,000 short of its source. The entrance to the lake was aljout a mile wide, and after passing this we came upon the Ta-koo-shan, or "Great Solitary Rock," rising out of the waters of the vast lake, and larger than the others, but less picturesque and striling in effect.

For the rest of the route to Hankow we were indebted (previous to Lord Elgin's expedition) to Du Halde and MI. Huc. The remaining distance from hence is about 157 miles. The first large city is Kew-keang, a few miles past the entrance of the lake, with the lake on its east and the rirer on its north side. Du Halde states, from the Jesuits' survey, that the tide is apparent here 
at new and full moon. He spealis of the porpoises, which we had ourselves observed, and states besides that salmon and sturgeon are canght as high up as this point. After averaging a westward course for about twenty miles to the mouth of a river on the right bank, flowing in from Hing-kwo, the Keang lies north-west and south-east from Hankow, the tirst city of consequence being Hwang-chow, on the left bank. Du Halde observes of this, that its neighbourhood to the great centre of commerce, Hankow, and the lakes and rivers in which the vicinity abounds, naturally render it very commercial and opulent. The comntry is highly cultivated, and rendered very pieturesque by the litls on the north. Turler its jurisdiction are eight towns of the third order (Hien), and one of the second (Chow).

Seventy or eighty miles above this city we reach the important eentral point where the three great towns of Wuchang, Hanyang, and Hankow lie at the confluence of the Hang-keangr with the Yang-tse. This aflluent of the great river is in itself no inconsiderable stream, rumning a course of six or seven hundred miles, including windingss. The three great cities form a sort of triangle, separated only by the water from each other. Wuchang is the capital of the double provines Hn-kwang (north and south), and the residenee of the

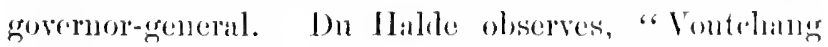
est eomme le centre de tont l'ompire, at le lina d'on il est plus nisé de se ropantre dans les antres provinees."

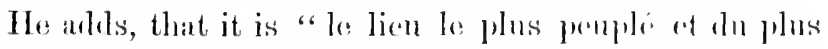
grand abord de la Chine." To any one who hats seen 
Shanghae, this must seem surprising. It is placed opposite to the confluence of the Hankeang with the Yang-tse. “Doubtless," says Du Halde, “in viewing only the forest of masts which borders that noble river the Keang, about a league in breadth at such a distance from the sea, there is sufficient ground for admiration; but if, on mounting some height, one comes to discorer that vast tract all covered over with buildings, one scarcely believes one's sight, or at least one belieres it to be the finest thing in the world of its kind."

Han-yang, the second city of Hu-kwang, is separated from the above only by the Keang, and lies at the western angle made by the confluence of the Hankeang with the Yang-tse. Hankow, on the opposite angle, is the mere growth of this immense commerce, which, in China, seems often to escape from the municipal trammels of the interior of walled cities and to fix itself on the outside, in order to breathe more freely.

It is some drawback to the splendid prospect held out to our future trade, to consider that the valley of the Keang, from Chin-keang and Nanking to beyond Hankow, has been for years in the power of the rebels; and that, as their occupation and pursuit hare been civil war and rapine instead of trade, the baneful effects must be very perceptible. But every one who has seen how speedily the Chinese repair the disasters of a fire, may feel sanguine as to the healing results of their indomitable industry :

"Mox reficit rates

Quassas, indocilis pauperiem pati." 
The adventurous and most interesting visit of Lord Elgin to Hankow now enables us to jurge of the existing state of the Keang and its cities. 'The Retribution, Furions, and Cruiser war-steamers, and Dove and Lee gun-boats, left Shanghat on the 9th of Norember. The shifting sands and shoals of the river had completely altered its chammels as far as Chin-keang since the survey of $18+2$, and the squadron did not reach that point under a week, when, as an additional delay, the Furious struck on a sunken rock between the south bank and Silver Island. On the 20th of November they reacher the healquarters of the rebels at Nanking. Having leen fired on pretty sharply in passing. the wise resolution was formed to drop down next morning with the stream and administer such a lesson as would prevent the Chinese repeating the agrogression on the return of the squatron; amd this was done in the completest mamer. It must be remarked that the Emperor's thect, close at home, was encouraged thereby to make an attack on the rebels' position immediately afterwards, thongh at a safe distnnce; a style of warfare which accomnts for this civil strife having dragered on in a chronic state for so many yeurs. The condition of the roldels, however, is decidedly retrograde. Thry have been driven from chintemen, which they before orenpicel, on the canal; their flonting forec has been displated liy the Emererores war-junlis along the whold of the Krang; and the expectition olservert that the

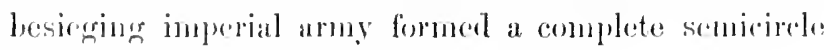
ahout Nomking by land.'

1 Nonking has since been titien, thanks to Colonel Gordon. 
The lesson at heatquarters was probably the cause of amicalle orertures being made from the rebel city of Tae-ping, on the right hank; and when our squadron reached Wu-hu on the $23 \mathrm{rd}$, after serions detentions by shoals, here again their fame had preceded them, and they were civilly received by the insurgents, whose appearance and condition conveyed anthing but a farourable impression of their character and resources.

Lord Elgin's expedition was just one montlı later in the season than that in which I. was a traveller, and the fallen condition of the river obliged the Retribution to remain at Kew-hein, literally "old town," some twentyfive miles above Wu-hu, and almost the only place at that time in possession of the Emperor's forces on the south bank, from Nanking to the highest point of rebel occupation towards the lake.

On the 26th Norember the expedition reached Ganking, the last post of the rebels to the westward. Being on the north or left bank, and the insurgents haring no means of communication across, while the city was actually beleaguered by the Imperialists, the proceedings at Nauking and elsewhere were probably unknown, and hence a fire was opened on our expedition, which was soon silenced. The Emperor's force again at this place was encouraged by what took place to attack the rebels after the steamers passed on. These inclications have an important learing on what mar be anticipated in the future. They denote a due appreciation of our power by the Imperial government, and must induce them to have us rather as friends than enemies. The sandbanks again impeded the narigation on approaching 
the Poyang Lake; thereabouts a f'w trading junks were for the first time observed, and the expedition was as much struck by the appearne of the Orplian or Solitary Rock (before described) as we had been so many years previously. After passing the lake's montl on the way to Hankow, the city of Kew-keme, on the sontl bank, was found in a state of completedesolation, thongh for some time ahantoned by the rebels. At Kechow, further on, was olserved the bollest amd finest scenery on the river, which is licre contracted within a gorge formed by the mountains on both sides.

It was not mitil the 6th December that the expedition reached Hankow, little less than a month alter puitting Shanghate lut still not much longer thin I was mracelf travelling (under Chinese conduct) only from Chin-keang to the Purangr, about half the distance.

After previous alcounts the actual condition of Hankow was espeecially disappointing. Every dwelling and hulding in the plate hat been demolished during the previons oceupation by the reliels; hut still much had becn restored. The shops and warehomses in one quarter are stated to have been umsually liage, and well furnished with a surprising supply of English and Enroperan groods. 'The opposite aty of Hanyang wats still a waste of puins; but Wuchang, the provincial city, on the sonth shore, alpearen in a muleh better condition, and corresponded nore nearly with former accomuts-exciting, inderd, cousiderable admintion in the expedition.

The propulation had, of course, suffered by the ro- 
morseless civil war, almost to extinction, and conld afford no grome whaterer for an estimate of its former numbers. The reception given by the governor-general of the two provinces to Lord Elgin was a very handsome one, promoted to some extent, no doubt, by what had been done to the rebels on the way up; and the people showed the greatest curiosity and desire to trade.

On the 11th December the expedition quitted Hankow on its return, and, after proceeding about thirty miles, found that the river was rapidly falling. After a week's incessant labour in working the steamers over the shoals only 130 miles had been accomplished, and on reaching the bar at the Poyang Lake not more than eleven feet of water remained, the Furious drawing fifteen feet. In fact, seven feet of water had fallen since they went up. Here the Furions and Crniser were left, while Lord Elgin and suite proceeded in the Dove and Lee to join the Retribution lower down. On the 29th December the three steamers reached Nanking.

The relels displayed, as might have been expected, a very peaceful disposition after their previous chastisement; and a risit being paid to the rebel chief, the interior of Nanking exhibited the same scene of ruin and desolation as the other places occupied by the rebels, whose sole business seems to be destruction withont any reproduction. It was erident they were hard pressed by the Emperor's force, and one of the chiefs made secret proposals to the English party to be allowed to desert his colours. Arrangements were effected for safe communication with the two ships up the river, and 
the mission reached Shanghae on the 1st January, after more than seren weeks' absence.

It was impossible to anticipate any other than the best results from this well-timed expedition by Lord Elgin. It seems to have tested with snecess the good intentions of the Peling Groverument, if we may julge from the conduct of their representative, the viceroy of Hu-kwang. But had it produced no other result than to establish a proper understanding with the rebels, and show them the folly of aggressive measures towards onr people, this alone was worth having. The cont of Peling probably hopes from us something better for itself than perfeet neutrality towads the rebels, and mily have been confirmed in this hope ly what the spuadron, in mere self-defence, was compelled to do arainst them up the river. Shonld this tend to secure good faith and practieal sincerity in the olservance of the new treaty wo may acerpt the results with satisfiction, without troubling omrselves as to the disinterestedness and purity of the motives. If the anthoritios are ancomaged to strennous exertion, and put a final enel to the robellion whieh has desolated the comitry and prarlyzed trade, this will be at great common benctit.

TIIF: FND. 



\section{MIR. MURRAY'S}

\section{GENERAL LIST OF WORKS.}

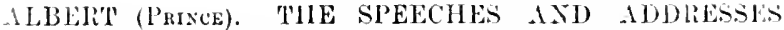
w1 Public occasions of II.R.JI. THE Plitick CONSOJT: with nu Introduction giving some Gutlines of his Character. Pur:rait, bro. 1's. 6el.; or Popalar Edition, feap. Svo, 1 s.

ABBOTT'S (Rev. J.) Philip Musgrave; or, Memoirs of a ('burch of England Missionary in the North American Colonies. Post Svo. 23.

ABERCROMBIE'S (JOHs) Enquiries eoncerning the Intellectual I'owers and the luvestigation of Truth. 16:h Edition. Feaj. Svo. 6s.6\%. Fcap. bro. $4 s$.

Philosol'hy of the Moral Feelings. 12th Edition.

ACLAND'S (liev. ChakLes) Popular Aecount of the Manners and Customs of India. Post 8vo. 2s.

WOPOS FABLES. A New Translation. With Hintorical P'reface. By liev. Thomas James. With 100 Woodeuts, by Texisiz. and WoLf. 50th Thousund. P'ost Svo. 2s.6d.

AGRICULTURAL (The) Jounat. Of the lioyal Agrieultural Society of England. 8vo. L'ublished half-yeurly.

AIDS TO FAlTH : a Series of Esays. By various IV riters. Edited by Willias Thoysus, D.1)., Lord A relibishop of York. bro. :'s.

CONTENT.

liev. II. I. ManskiL-Miracles.

BDEH, UF KILLALOE-C'kristiun Evideteres.

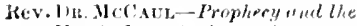
Hesraic liecord of Creation.

liev. Casus Couk - Ideology and Subscription.

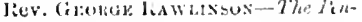
listeuch.

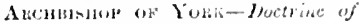
the stonement.

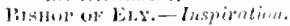

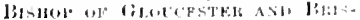
7ol..-Sicripture and ats Jntriphlation.

AMBER-WITCII (THE). The most interesting Trial for Witebcraft ever known. Transtated from the German by LALY ICA. Gorbos. Jost svo. 2\%.

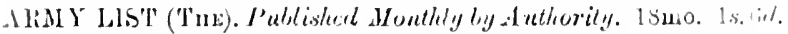

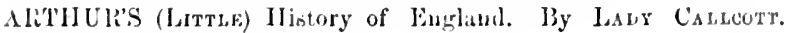
13ith 'Thousand. Woudectits. lecap.swo. 2y.6d.

ATlisison's (Mnso) liecollections of 'lartar steptes and their

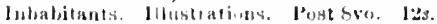

AUN'T IJA's Walks and 'latks; a Story Book for Children. By a loApr. Wordcuts. 16ino, bs.

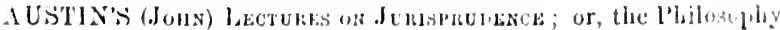

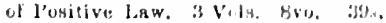

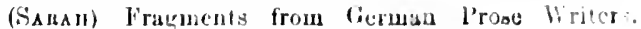
Wibl Liographical Noters. loot 8 vo 10, 


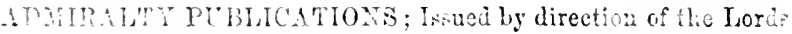
Comentstoners of the Aumiratis:-

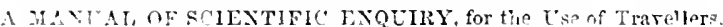

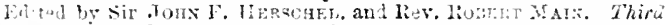
Fitirn, Woodeuts, Post Sro. 9s.

AIRY ASTRONOMICAL ORSEPVATIONS Mad AT GEEETICL. 836 to 1817 . Iiosal tio. 50 s, each.

ASTRONORHCAL RESLLTS. 1Sis to $155 \mathrm{~s}$. 4to. Ea fach.

APPLNDICE TO TIE ASTRONOMICAL OBSERTA. TIONS.

:36.-I. Tessel's Refiaction Tables.
It. Tables for converting Errors of R.A. and N.P.D. $\}$ S.s. into Errors of Longitude and Ecliptic P.D. $\$ 3 \pi .-i$. Ingarithms of Sines and Cosines to every Ten?
Seconds of Time.

II. Table forconverting Sidereel into hean Solar Tine. $\int$

1812.-Catalogue of 1439 Stars. 8s.

1815.-Inngitude of Valentia. 8s.

1847.-Twelve Years' Catalogne of Stars. $14 s$.

$1551,-$ Maskelyne's Ledger of Stars. $6 s$.

155\%-I. Descriptiou of the Transit Circle. 5\%.

II. Regulations of the Rosal Obserratory. is.

1Si3.-B bssel's Refraction Tables, 3s.

155x.-I. Description of the Zenith Tube. $3 s$.

II. Six Years' Catalogue of Stars. $10 s$.

:S56.-Description of the Galranic Apparatus at Greenfich Ob. servators. 8s.

MAGNETICAL AND METEOROLOGICAL OBSERYATIONS. 1810 to 1817 . Royal 4to. 50s. each.

- ASTRONOMICAL, MAGNETICAL, AND METEOROLO. GICAL ODSERTATIONS, 18 18 to 1862. Fojal 4to. 50s. eac?.

- ASTROXOMICAL RESLLTS. 1948 to 1862. 4to.

MAGNETICAL AND METEOROLOGICAL RESLLTE. -Sis to 1862 . 4 to. Es, each.

- IEDUCTION OF TIE OBSERTATIONS OF PLANETS 1750 to 1850 . Roral 1 to. 50s.

to 1850.2 VoIs. Ropal 4to. 50s. eacli.

LUNAR OBSERTATIONS. 17E 1831 to 185.4 . 2 ) 5.

73EIPOCLIIS SLACENTENARY TABLE. London, 17\%9. 4 to.

RESSELS AUXILIARY TAPLES FOR HIS METHOD OE CLEAP. INǴ LCNAR DISTANCES. Sro.

FEXDAMENTA ASTROROMIE: Regiomontii, 1513. Folio. $60 \mathrm{~s}$.

I.IRD'S METIOD OF CONSTRUCTING MURAL QUADRANTS Lovion, 176s. 4to. 2s.6d.

- METHOD OF DIVIDING ASTROXOHICAL IXSTREMEXTS. London, 1767. 4to. 2s.67.

COOK, KING, AND BAIIY'S ASTRONOMICAL ODSERTATIONS. Io.2don, 17\$2. 4to. 21 s.

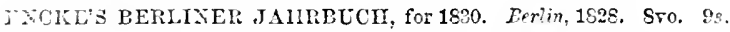

FPOUMBRIDGE'S CATALOGUE OF CIRCUMPOLAI STARS. 4 to. $10 \mathrm{~s}$.

IIA YEN' TABLES DE LA LCNE. Ato. 208.

AHCTONS PRIXCIPITS OF HIS TIME-KEEPEI. PUTF, 1797. 410. 58 . 
ADmaraty l'ulicicatons-cuntinucd.

HUTTON'S TABLES OF TIE IRODLCTS AND POWLISS OE NUMBEIS. 17Si Folio. T\&.6i.

LAX'S TABLES FOR FINDING THE LATITUDE AND IONGITUDE. 14?2. Oro. $10 s$.

LUNAR OBSERVATIONS at GRLFNWIII. 1783 to 1SI9. Compared with the Tables, 1,21 . 4 to. 7 s. 6.2 .

DASKELYYIS ACCOEXT OF TIE GOING OF IIAREISON'S WATCH. $176 \%$. 4to. $2 s .6 l$.

MAYER'S DISTANCES of the MOON'S CENTRE from the PLANETS. IS22, 3.; 1823, 4s.6\%. 1524 to 1835, Svo. 4s. each.

- THEORIA LUNA JUXTA SYSTEMA NEWTONIAXUM. 4to. $2 s .6 d$.

-.. - TADULA MOTUUM SOLIS ET LUNA. 17i0. 4\%0. 5 ASTIONOMICA! OBSERVATIOXS MADE AT GOT. TISGEN, from 1756 to $176 \mathrm{l}$. 132G. Fulio. Ts. Cil.

NAUTICAL Al,WAXACs, from 1767 to 1869 . Svo. 2s. 6 . each. SELECTIOXS FROA THE ADDITIONS

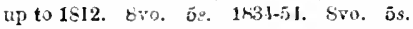

Sro. 2s. ench.

SUIPLE.MENTS, 102S to 1923, 1837 and 1538.

1781. Sro. 5\%

JOND'S ASTRONOHICAL OBSEIVATIONS. $15: 1$ to 1Es. 4to. 21s. each.

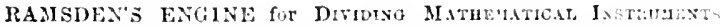
4 to. 5 s.

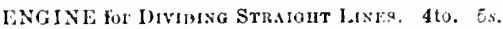

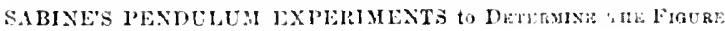
OF THE liATH. 1525. 4to. 40s.

SHEIIIERD'S TABLES for Correcting Loxar Distaxces. 1772. Royal ttu. 21s.

TABLES, GENERAI, of the IIOONS DISTANC:: from the SUN, and 10 STMLS. 176. Folio. 5.6. $6 \%$

TAYLOR'S SEXAGLSIMAL TAILE. 1780. 4lo. $15 \mathrm{~s}$.

TALLES OW LOGARITIMS. Aio. 3i.

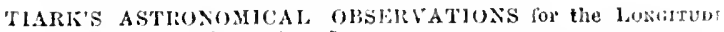
of HADEHLA. 1822. 4lo. 58.

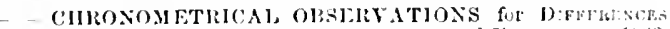

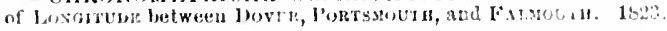
4 to. $5 i$.

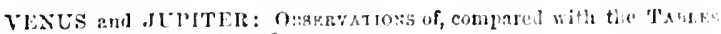
Loud $(m, 1822$. 4to. $2 s$.

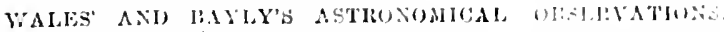
1777. Atก. 2!s.

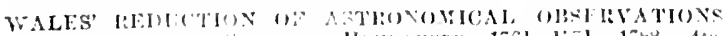

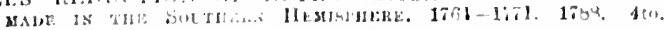
$111 ., 6, \%$.

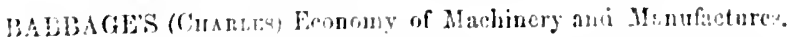
Fourth Bitition. Findp. Svo. Be.

Reffections on tho Teeline of Sciense in lin land,

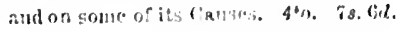


B.1liles (W. B.) Narrative of an Exploring Voyage up the livers Quorra and Tshado in 1554. Map. Svo. 16s.

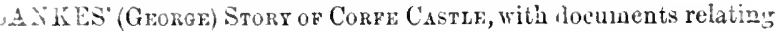
to the Time of the Ciril Wars, \&e. Wuodcuts. Post bro. 10s. El.

BjilibiULD'S (MRs.) Hymns in Prose for Children. Witl 112 origlual Desigus. Small 4 to. 5s.

Zinliurs (Sin Jons) Autobiographical Memoir, including Resections, Obserrations, and Reminiscences at llome and Abroau. From Early Life to Advanced Age. Portrait. 8ro. 16s.

Voyages of Discovery and Research within the Arctic legions, from 1818 to the present time. Svo. $15 \mathrm{~s}$.

rous Original Letters. Host Sro. $2 s$.

LiAlYS' (H. W.) Records of a Naturalist on the River Amazons during eleren years of Adrenture and Trarel. Secon! Edation. Hisslratious. Post bvu. 12s.

BEES AND FLUivers. Two Essays. By Rer. Thomas James. Repriuted from the "Quarterly Review." Fcap. 8vo. 1s. each.

BELlis (Sir Charles) Mcchanism and Vital Endowments of the lland as evincing Design. Sixth Edition. Woodcuts. Post sro. 6s.

BERTHA'S Journal during a Tisit to her Uncle in England. Containing a Variety of Interesting and Instructive luformation. Seventh Bdition. Woodcuts. $12 \mathrm{mo}$.

BILCH'S (SAYUEL) History of Ancient Pottery and Porcelain : Cgyptian, Assyrian, Greek, Roman, aud Etruscan. With 200 Illustrations. 2 Vols. Medium 8 ro. $42 s$.

L'LUNT'S (REv. J. J.) Undesigned Coincidences in the Writings of the Old and New Testament, an Argnment of their Veracity : contriving the Booke of Moses. Hintorical and Prophetical Scriptures, and tha Gospels and Acts. 8th Edition. Post 8vo. 6s.

History of the Church in the First Three Centuries. Third Edition. Post 8vo. 7s. $6 d$.

- Parish Priest; His Duties, Acquirements and Obligations. Fourth Edition. Post 8vo. 7 s. 6 .

- Lectures on the Right Use of the Early Fathers. Second Edition. Sro. 15 s.

P'ain Sermons Preached to a Country Congregation. Second Edition. 3 Vols. Post Svo. 7s.6d. each.

Essays on varicus subjects. 8 vo. $12 \mathrm{~s}$.

BISSET'S (Andrew) History of England during the Interregnum, from the 1) ath of Charles I. to the Battle of Dunhar, 1645-50. Chicfly from the 31.SS. in the State Paper Otfice. Svo. 15s. 
BIAKISTON'S (CAPT.) Narrative of the Expedition sent to explore the Llerer Waters of the laug-T'sze. Jliustrations. Swo in.

DIOMFIELDS (Branop) Memoir, with Seleations from his Corre-

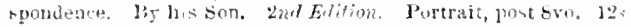

POOK OF COMMON PRAYER. Illustrated mith Contred Borders. Initial betters, and Woodents. A nell edition. Evo. 14. clotiı; 31. Gr. calt; 3rs. morocen.

PORPOW'S (George) Bible in Spain: or the Journeys, Adventures, and Imprisonments of an Englishman in an Attunipt to circulatis the Scriptures in the Peninsula. 3 Vols. Post 8 ro. 27s, or Popular Fidition. $16 \mathrm{mo}, 3 s .6 \mathrm{el}$.

Zincali, or the Gipsies of Spain; their Mannerp, Customs, Relinion. and Language. 2 Vols. Jost Svo. 15s.; or lopulin Eddition, 16mo, $3 s, 6$.

Lavengro; The Seholar-The Gipsy-and the Priest Portrait. 3 Vols. Post 8vo. 30s.

Romany Rye; a Sequel to Isavengro. Secone? Edition. 2 Vols. Yost svo. 21s.

Boswelds (JANes) Life of Samnel Johnson, LL.D. Including the Tour wo the Hebrides. Edited by Mr. Crokft. Jortraits. Kir:at 8 ro. 10 .

13li.LCE'S (C. I.) Ifictory of the liaces of the Ohl World. Desiornel

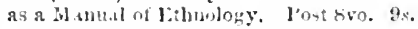

BRAY'S (Mrs.) Life of Thomas Stothard, I.A. With Perana? Reminiscences. Illustrated with Portrait and to Voodeuls of hi. clitef works. 4to.

BREWSTER'S (SIR David) Nartyrs of Seience, or the Lives of Galileo, Tycho Irahe, and Kiplur. Fourth Edition. Fcap. 8vo. 4s. 6rt.

More Worlds than One. The Creed of the I'hilo. bopher and the llope of the Christian. Fighth Liditim. I'ost 8vo. 6s.

Stereoscope: its IIistory, Theory, Construction, and Application to the Arts and to Education. Woodeuts. 12m, $68.6 d$.

Kaleidoscope: its IIstory, Theory, and Construction, with its application to the line and Useful Arts. Second tidion Woodents. I'ost svo. 5s.6it.

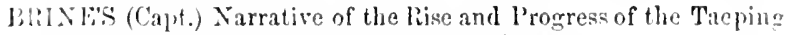
labblisin in Clina. Jlans. l'ost kro. 10s. 6it

BRITISH ASSOCIATION REPORTS. 8vo. York and Oxforl, 1831-32, 13s. fol. Cambrides, 1833, 12s. Ellinburkl, 15.3t, 15s. Jublln,

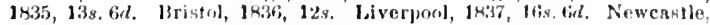

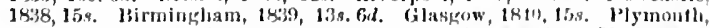
1811, 13\%. fid. Manchester, 18I2, 10s. Gd. Cork, 1812, 12s. York, 1HA1,

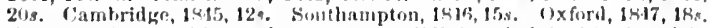

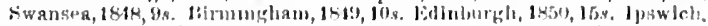

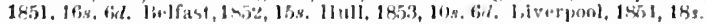

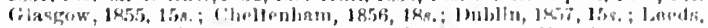

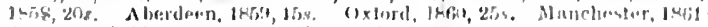

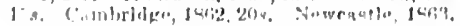


BRITISI CLASSICS. A Now Series of Standard English Authors, printed from the mest correct text, an l edited with notes. swe.

Aready Published.

1. GoLDS.MITI's WORKS. Edited by PeTER Coxisgmam, F.S.A. Vignettes. 4 Vols. Sos.

II. GIBBON'S DECLINE AND FALT, OF TIE ROMAN EMPIRE. Edited by Wilias smiri, LL.I) Portrait and Maps. 8 Vols. 60s.

III. JOHNSON'S LIVES OF TIIE ENG!ISII POETS. Edited by PateB CixNisgham, F.s.A. 3 Vols. 2\%s. 6rd.

IV. BYRON'S POETICAL WORKS. Edited, with Notes. 6 rols. \&üs.

\section{In Preparation.}

WORKS OF POPE. Wih Life, Introductions, aud Notes, by Rev. WuitWELl Elwis. Portrait.

HUME'S HISTORY OF ENGLAND. Edited, with Nates.

LIFE AND WORKS OF SWIFT. Edited by JoHN Forster.

BROUGHTON'S (LORD) Journey throngh Albania and other Prorinces of Turkey in Enrope and Asia, to Constantinople, 1509-10. Third Edition. Illustrations, 2 Vols. Svo. 30s.

Tisits to Italy. 3 rd Edition. 2 rols. Post 8 ro. $18 s$.

BUBELES FROM THE BRUNNEN ON NASSAU. By an O!d Man. Sixth Euition. 16mo. 5s.

BUNYAN (JOHN) and Oliver Cromwell. Select Biographies. By Rueert Southey. Post Svo. $2 s$.

BUONAPARTE'S(NA POLEON) Confdential Correspondence with his Brother Josepl, sometime King of Spain. Stcond Edition. 2 vols. 8vo. $26 s$.

BURGON'S (Rer. J. W.) Mlemoir of Patrick Fraser Tytler. Sec\%d Edition. Pest 8ro. 9s.

Letters from Rome, writton to Friends at Homs. Illustrations. Post 8vo. 12s.

BURN'S (Lreut.-Cor.) French and English Dictionary of Naral and Military Techuical Terms. Fourth Edition. Crown 8vo. 15 .

BURNS' (Robert) Life. By Jozn Gibson Lookgart. Fifth Edition. Fcap. 8ro. $3 s$.

BURR'S (G. D.) Instructions in Practical Surveying, Topographical Plan Drawing, and on sketehing ground without Instruments. Fourth Edition. Woodents. Post \$vo. 6s.

BUTTMIAN'S LEXILOGUS; a Critical Examination of the Mearing of numerous Greek Words, chiefly in Homer and Hesiod. Translated by Rev. J. R. Fishlake. Fifin Eitition. Sro. 12s.

BUXTON'S (Sir Fowell) Memoirs. With Selections from his Correspondenee. By his Son. Portrait. Fijth Edition. 8ro. $16 s$. Abridged Edition, Portrait. Fcap. 8vo. 2s. $6 a$. 


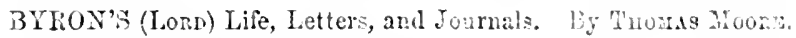
Plates. Q Vols. Fcap. Sro. 18 s.

Life, Letters, and Journals. By Troms Moons. Portraits, loyal 8ro. 9s.

- Poetical Works Portrait. 6 Vols. Evo. 15s. Poetical Works. Plates. 10 Vols. Feap. sro. Sos. Poetical Worke. 8 Vols. 24mo. 20.

- Poctical Works. Plates. Iloyal Sro. S.

-... Poetical Works. Portmit. Crown Sro. is. Chike Irarold. With So Engravings. Simall tto. 21s. Childe Harold. With 30 Vignettes. 12wo. os. Childe IIarold. 16mo. 2s. $6 d$. Childe Harold. Vignettes. 16mo. 1s. Childe II arold. Portrait. $16 \mathrm{mo}$. bel. Tales and Poems. 24mo. 2s. 6cl. Miscellaneous. 2 Vols. $24 \mathrm{mo}$. 5\%.

Dramas and Plays. 2 Vols. $24 \mathrm{mo.} 58$. Don Juan and Beppo. 2 Vols. 2 mo. Es.

Benuties. Selected from his Poetry and Prese. Portrait, . Teap.8w. 3s. $6 d$.

CARNARVON'S (Lono) Fortugal, Gallicia, and the Batenc Provinces. From Notes mado during a Jou:ney to those Countrist. Third Lation. Post Svo. 3s, 6id.

Recollections of the Druses of Lebanon. Fit!

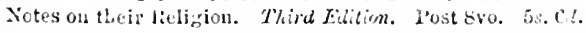

CAMPBELL'S (Lori) Lives of the Lord Chancellors and Feepers of the freat seal of Lngland. From the karliest Times to the Dean of

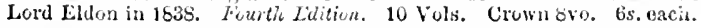

Jives of the Chief Justices of Fugland. From the Xorman Conquest to the Death of Lord Tenterden. Second Latiticu. 3 Vols. 8 vo. $42 s$. 8vo. 5s. 6l.

Shalspeare's Legal Aequirements Considered. Life of Lord Chanecllor Bacon. Feap. Sro. 2s. C.'

(Georgr) Modern India. A Sketch of the Syrten:

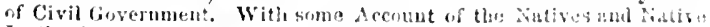
Institutions. Second Edition. Evo. 16s.

India an it may be. An Gubline of a propoied Government and l'olicy. Svo. 1:s.

('Tnos.) Short Jives of the liritikl l'octa. With an lisiay on linglish poetry. Lost swo. 3s. i,l.

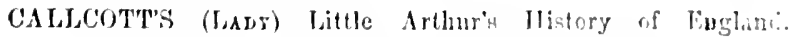

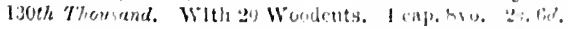


C.ISTLEREAGH (THE) DESPATCHES, from the commeneement of the efficial career of the late Viscount Castlereash to the close of his

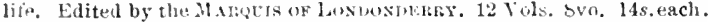

('ATHCART'S (SIR Geongf) Commentaries on the War in Russia and Germany, 1812-13. Plans. Sro. 14s.

CATALCASELLE AND CROWE'S Xew History of lainting in Italy, from the secrim to the sixpenth Century, from recent reserathes in the Archives, as well as from personal inspection of the Works of Art in that Gountry. With 70 Ilmstrations. Vols. 1. and 11. (250. 4.s.

Notices of the Lives and Works of the Earls Flemish Painters. Woodcuts. Post 850, 12.

CHAMBERS' (G. F.) Handbook of Descriptive and Practical Astronomy, lihtration; Post 8 vo. $12 \mathrm{~s}$.

CIARMED ROE (THE) ; or, The Story of the Jittle Brother ans sister. ВуОтто S̈ескти. Plates. 16 mo. $5 s$.

GITTTON'S (Arempeacon) Gongora. An Historical Essay on the A re of Philip IlI, and IF, of Spain. With Translations. Portraic. 2 Vols. small $\mathrm{s}$ \% 15 .

CLAUSEWITZS (CARL ToN) Campaign of 1812, in Rusia. Translated from the German by Lord Eltesmere. Map. 8vo. 10s.6 .

ritive's (Lord) Life. By Rev. G. R. Gleig, M.A. Post 8vo. 3s.6d.

COLCIIESTER (THE) PAPERS. The Diars and Correspondence of Charles Abbott, Lord Colchester. Speaker of the Ilouse of Common, 1802-1817. Edited by IIIs sos. Portrait. 2 Vols. Swo. 42s.

COLFmidge's (Samof Tarlon) Table-Talk. Fourth Eltion. Portrait. Fcap. Svo. 6s.

COLONIAL LIBRARY. [See Home and Colonial Library.]

COok's (Rer. Canon) Sermons Preached at Lincoln's Inn Chapel, and on Spectal occasions. 8ro, is.

COOKERY (Modran Domestic). Founded on Principles of Economy and Practical Knowledge, and adapted for Prirate Families. BY a lady. New Eaition. Woodcuts. Fcap. Sro. 5s.

CORNWALLIS (The) Papers and Correspondence during the American War, - Administrations in India,-Cnim with Ireland, and Peace of Amiens. Ldited by Charles Ross. Second Edition. 3 Vols. Svo. 63s.

COWPERS (ATARr Cotxtess) Diary while Lady of the Bedchamber to Caroine Princess of Wales, 1711-20. Srond Edilion, Portrait. 8vo. I0s. $6 \%$.

CRABBE'S (Rev. Gronge) Life, Letters, and Journals. By his Son. Portrait. Fcap. Svo. 3s.

- Life and Poetical Works. Plates. 8 Tols. Feap. s. 21s.

Life and Pnetical Works. Plates. Royal 8ro. 7s. 
CROKER's (J. W.) Progressive Geography for Children. Fifth Erition. 19mn. 1s.6d.

Stories for Children, Selected from the IIistory of England. Fiftisnth Edition. Woodeuts. 16mo. 2s.6l.

Boswell's Life of Johnson. Ineluding the Tour to the Hebrides. I'nrtraits. Royal 8 ro. $10 s$.

Essays on the Early Period of the Frencli Revolution. Sro. 15 .

- Historical Essay on the Guillotine. Fcap. Sro. 1.s.

CROMwell (Oriver) and John Bunyan. By Robert Soutner. Post Sro. 24.

CROWE'S AND CATAICASELLE'S Notices of the Farly Flemish lainters; their Lives and Works. Wonderits. lost Svo. I2s.

Ilistory of Painting in Italy, from 2nd to 16th Centurs. Derived from listorical lienesrihts a with

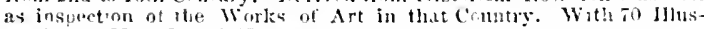
lrations. Vols. 1. and II. Eve. 42s.

CUnninghan's (Artan) Pocms and Songs. Now first coll.ected and arranged, witl Biograplical Notice. 2tmo. 2s.6a.

CURETON (IREv. W.) Remains of a rery Aneient liccension of the Four cosnels in Syriac, hitherto unk nown in Borope. Discovered, Edited, and Translated. 4 to. : $21 s$.

CURTILS' (ProfEscon) Student's rireek Grammar, for the nse of

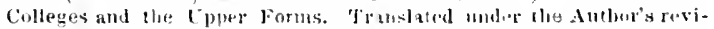

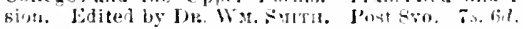

Smallel Greek Gramnar for the nse of the Midlde and

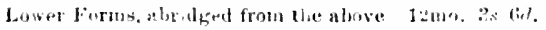

First Greck Conrse; eontaining belectus, Bxereise brok, and Vocalulaties. 1:3mo. 3is tirl.

CURzon's (How. Robert) Armenia and Ekzerous. A Year on the Frontiers if Rinssid, Turkey, and Persit. Third Edition. Wund. cuts. l'ost 8vo. 7s. tid.

CUST'S (Gewaral) Annals of the Wars of the 1 sth s 19 th Centuries. 9 Vuls. Feap. svo. 5x. each.

Lives and Characters of the Warrinrs of All Nations who have Commanded filets and Armies before the linemg.

DARWIN'S (Chartess) Tournal of licsearches into the Natural llistory of the Countries visited during a Voyage round the World. post sovo. fis.

Origin of Species ly Means of Natural Selection;

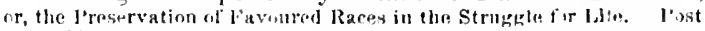
8 inn. $14 s$.

Fertilization of Orehils through lnonet $A$ inener, and

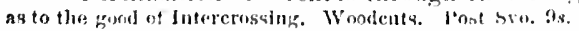

D.IVISS (Natras) Visit, to the liuined Cities of Numidia and Carthaginia. Illustrations. Roo. lis.

DAVY's (Sra Humbres) Consolations in Travel; or, Last Days of a l'hilosopher. Fith sitition. Wondents. Feap. Ron. Fis.

Salmonia ; or, lays of Fly Fiahing. Finth litifiom. Wondeuts. Feap. Aun. Bis. 
DELEPIERRE'S (OCTArE) Mistory of Flenish Literature. From the Twelfin Century. Swo. 9s.

DENNIS' (Georas) Cities and Cemeteries of Etruria. Plates. 2 Vols. Sro. $42 s$.

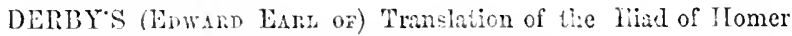
into Engtish blank Verse. 2 Yols. Sro. 219.

DIXON'S (Hepworth) Story of the life of Lold Bacon. Portrait. Fcap. Sro. $7 s, 6 u$.

DOG-BREAKING; the Most Expeditious, Certain, and Easy If ethod, whether great excellence or only mediocrity be required. By Lievt.-Ges. IIUTChissos. Fourth and lituised Edition. With additional Woodcuts. Crown Sro.

DOMESTIC MIODERN COOKERY. Founderl on Principles of Economy and Practical Knowledge, and adapted for Private Families. New Edition. Woodcuts. Fcap. Svo. $5 s$.

DOUGLAS'S (General Sir Howard) life and Adventures; From Notes, Conversations, aud Correspondeuce. By S. W. Fullow. Portraic. Svo. 15s.

- On the Theory and Practice of Gunnery. 5th Elition. Plates. 8vo. 21s.

Military Bridges, and the Passages of Riwers in Xlilitary Operations. Thiol Edition. Plates. Sro. 21s:

8s. $6 d$.

Naval Warfare with Steam. Second Edition. Sro.

Modern Systems of Fortifieation, with special reference to the Naval, Littoral, and Internal Defence of England. Plans. 8 ro. $12 s$.

DRAKE'S' (Sir Francis) Life, Voyages, and Exploits, by Sea and Land. Bу Johx Barnow. Third Edition. Post 8ro. 2s.

DRINKWATER'S (JoHN) History of the Siege of Gibraltar, 1779-1783. With a Description and Account of that Garrison from the Earliest Periods. Post Sro. $2 s$.

DU CHAILLU'S (PAUL B.) EQUATORIAL AFRICA, with Accounts of the Gorilla, the Nest-building Ape, Caimpanzee, Crocodile, \&c. Illustrations. 8ro. 218.

DUFFERIN'S (LoRD) Letters from High Latitudes, being some Account of a Yacht Voyage to Icelaud, \&c., in 1856. Fourth Edition. Woodcuts. Post Svo. 9s.

DYER'S (Thomas H.) History of Modern Europe, from the taking of Constantinnple by the Turks to the close of the War in the Crimea. 4 Vuls. Sro. 60 s.

EASTLAKE:S (Sir Charles) Italian Schools of Painting. From the German of KugLer. Edited, with Notes. Third Edition. Illustrated from the Old Masters. 2 Vols. Post Svo. 30s.

EASTWICK'S (E. B.) Handbook for Bombay and Madras, with Directious for Travellers, Ofticers, \&c. Map. 2 Vols. Post 8vo. $24 s$.

FDWARDS' (W. H.) Voyage up the River Amazon, including a Tisit to Para. Post Sro. $2 s$. 
ELDON'S (Lonn) Public and Private life, with Selections from his Correspondence and Diaries. By $110 \mathrm{R} \Delta \mathrm{CE}$ Twiss. Third iuid: n P'ortrait, 2 Vols. Post Svo. 218.

ELLIS (REv. W.) Visits to Madagasar, including a Journey to the Carital, witis notices of Natural Ilistory. and Present Civilisation of the People. Fifh Thousand. Map and Woodcuts. Sto. 16 s.

(Mrs.) Education of Character, with Hints on Dioral Training. Post Svo, 7s.6d.

ILLESMERES (LORD) Two Sieges of Vienna by the Turlis. Translated from the German. Post 8 ro. 2s.

Campaign of 1812 in Russia, from the German of General Carl Ton Clausewitz. Map. Sro. 10s.6 $u$.

Poems. Crown 4to. $21 s$.

- Essays on History, Biography, Geography, and Engincering. 8vo. $12 s$.

ELPHINSTONE'S (HoN. MoUNTSTUART) IIistory of India-the Jlindoo and Mahomedan Periods. Fouth Lation. Map. Svo. 1 s.

EXGEL'S (CARx) Music of the Most Ancient Nations; partieularly of the Assyrians, lipsptians, and llebrews; will specist Ileferences is

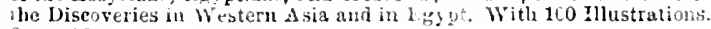
Svo. 16s.

ENGIJAND (IIsTorr of) from the Peace of Utrecht to the Peace of Versailics, 1713-53. Iy Lown Manox (Lasl Stanloge). Lilirary Eution, 7 Fols. Svo. 93s.; or Irpulet Eutition, 7 Vols. Just svo. 3.s.

From the First Invasion loy the Romans, down to the 1fth year of Queen Vietoria's Iieign. By ilus. MakkHas. 11sth Edition. Woodeuts. 12mo. $6 s$.

(The Stunent's Hune). A History of England

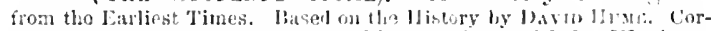

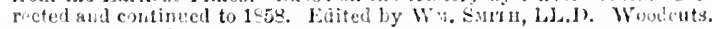

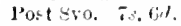

ENGLISHWOMAN IN AMERIC.1. Post Sro. 10s. $6 d$.

ESKINIUX and English Voeabulary, for Trarellers in the Aletis Regions. $1 \mathrm{cmo}$. 3s. $6 a$.

ESSAYS FROM "THE TIMES." Being a Selection from the

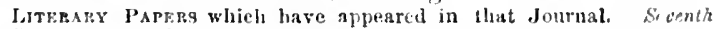
Thousard. 2 vols. Feap, Svo. 8 s.

EXETER'S (Bronop or) Jetters to the late Charles Butler, on the Theolngical parts of his lionk of the lioman ('atholsc chureh: with kemarks on certain Works of Jr. Milnter and Dr. Jine:url, ind on solue parts of the lividence of Dr. Doyle. Second Edition. swo. Ifis.

FAMIJY RECEIPT-BOOK. A Collection of a Thousand Valualile and Useful facecipts. Feap.svo. Eq. Cid.

FARRAR'S (Rler. A. S.) Critical History of liree Jltonghtib in

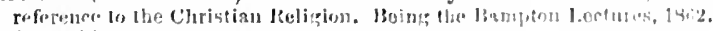
Swo. 16 s.

(F. W.) Brigrin of Langutare, labsed on Moleru lesearchere licol swo. is. 
FEATHERSTONHA UGH'S (G. W.) Tour through the Slave States of North Anerica, from the liver lotomac to Texas and the Frontiers if yexico. Plates. 2 Vols. 8vo. 26s.

FErgussors (JAMes) Palaces of Nineveh and Persepoliz liestored. Woulcuts. Svu. liss.

- History of the Monlen Strles of Arelitecture, completing the above work. With :12 Illustrations. 8vo. 31s. (it.

FISHER'S (Rew. GEoRge) Elements of Geometry, for the Use of Schools. Fifth Edition. 1Smo. 1s. 6et.

First l'rinciples of Algehra, for the Use of Schools. Fifth Edition. 18mo. 1s. $6 d$.

Flower GaldDEA (The). By Rer. Thos. Jayes. Fean. S:o. Is.

FoxyerkdUs (T. G.) liary of a Dutiful Son. Feap. $8 \mathrm{~m}$. 4. $6+1$.

FORBES' (C. S.) Iceland; its Tolcanoes, Gevsers, and Glaciers. Illustrations. Yost sw. 148.

FORD'S (Ricrard) Handbook for Spain, Andalusia, Ronda, Talencia, Catalonia, Granada, Gallicia, Arragon, Navarre, \&c. Thivd Editimu. 2 Yols. Post 8 vo. 30 s.

Gatherings from Spain. Post 8ro. 3s. 6d.

FORSTEP'S (JOHN) Arrest of the Fire Members by Charles the First. A Chapter of English llistory re-written. Post 8ro, 1:er.

Grand Remonstrance, 1641. With an Es₹ay on Inglish freedom under the Plantagent and Tudor Sovereigns. Drocunt Edition. Post Sro. 12s.

Oliver Cromwell, Daniel De Foe, Sir Richard Stcele, Charles Churchill, Samnel Foote. Third Edition. Post Sro. 12.

FORSYTH'S (William) Life and Times of Cicero. With Selections from his Correspoudence and his Orations. Illustrations. 2 Vols. Post Evo. 18.

FORTUNE'S (Robert) Narrative of Two Tisits to the Tea Countries of China, 1543-52. Third Edition. Woodents. 2 Yols. Post 8vo. $18 s$.

Third Tisit to China. 1853-6. Woodents. Sro. 16s.

Yedo and Peking. With Notices of the $A$ rriculture and Trade of Japan and China. Illustrations. Svo. $16 \mathrm{~s}$.

FOSS' (Edward) Judges of England. With Sketehes of their Lives, and Notices of the Courus at Westminster, from the Conquest t, the Present Time. 9 Vols. Sro. 114 s.

FraNCE (History of). From the Conquest by the Ganls to the Death of Louis Philippe. By Mrs. MArkHay. 56th Thousand. Woodcuts, $12 \mathrm{mo}$, 6s.

(The Student's History of). From the Farliest Times to the Establishment of the Sacond Empire. 1852. By W.11. PzARson. Edited by W.s. SMith, LL.D. Woodcuts. Pust $\varepsilon_{\text {ro. }} i s .6 e$.

FRENCH (THE) in Algiers: The Soldier of the Foreign Legionand the Prisoners of Abd-el-Kadir. Tranclated by Lady Duff Gornox. Post Ero. $2_{S}$. 
GaLTON's (Francis) Art of Travel; or, llints on the Shits ant Contrivances avaitabie in Wild Countries. Thurd Elition. Wood cuts. Post sro. Ts. $6 . l$.

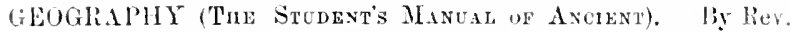

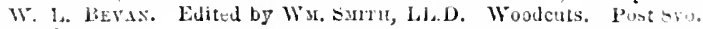

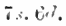

London. Sro.

Journal of the Royal Geographical Soeiety of

GERHANY (History of). From the Invasion by Marius, to the present time. By Mrs. Maвкuas. Fifteenth Thousand. Woodcuts, 12mo. G.

GIBBON'S (EDward) History of the Deeline and Fall of the Liman Enpire. A Now Exition. Preceded by Lis Autobiography. Edited, with Notes, by Dr. Ws. Ssitu. Maps. 8 Vols. Svo. 6us.

(The Student's Gibbon); Being an Epitome of the ahove work, incorporating the Researches of Recent Commentators. lyy Dr. Wx. Ssirm. Ninth Thuesend. Woodcuts. Post 8vo. iss. $d d$.

GlFFARD's (Eowari) Deeds of Naval Daring; or, Aneedotes of the British Navy. New Ldition. Fcap. Svo. 3s. 6d.

GuLDSMITII'S (Olivkn) Works. A New Edition. Printed from the list editims revised by the Anthor. Edited by PrTen CussisuHasl. Vignettes. 4 Vuls. svo. 30s. (Minrrity's British Clissics.)

GLADSTONE'S (Rirat Hux.W. E.) Financial Statements of 1558 ,

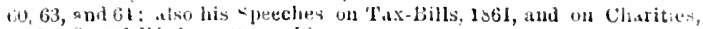
1963. Srcoml Eilution. Sro. I's.

Hedgwood: an Aldtress delivered at burslen. Woodcuts. Post swo. 2s.

GLEIGS (Rry. G. R.) Campaigns of the British Army at Washing. ton and New Orlears, p'ust sro. "ys.

Story of the Battle of Waterloo. Post svo. ss. 6i\%.

Narrative of Sale's Brigade in Atrginanistan. P'ost 8 ro. $2 s$.

Life of Iiobert Lord Clive. Post 8vo. 3s. bid.

Life and Letters of Sir 'Thomas Munro. Post Sro 3s. bel.

GORDONS (Srr A rex. Durr) Sketehes of German Life, and Scenes from the War of Liberation. From the German. Post 8 ro. 3s. jicl.

(Ladr Durr) Amber-Witeh: A Trial for Wir.h. craft. From the German. Post bvo. 28.

French in Algiers. 1. 'The Soldier of the Foreign Legion. 2. The Prisoners of Abd-el-kadir. From the Frencl. P'ost sio. $2 s$.

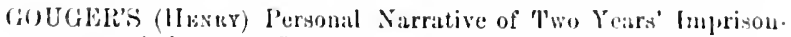

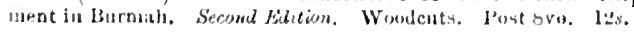

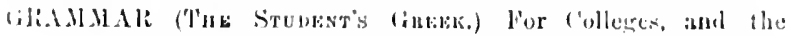

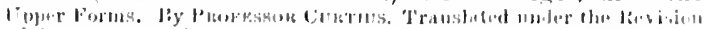

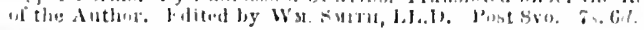

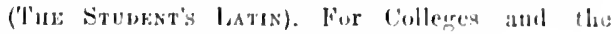

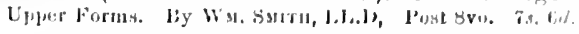

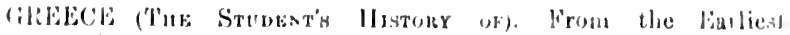

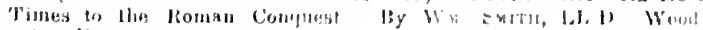

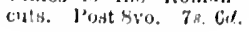


GIENVILEE (The) PAPERS. Being the Public and Private Correspondence of Genge Grenvile, including his Private Diarr. Euited by W. J. Sxizu. 4 Vols. 8ro. 16s. each.

GEEl (Faris) on Parliamentary Government and Reform. A New Edition, containing Suggestions for the Improvement of our RepreEentatire System, and an kxamination of the Reform Bills of 1859-61. sro. $9 s$.

GREY'S (Sir George) Polynesian Mytholozy, and Ancient Traditional History of the New Zealand Iace. Wooderats. Post Sro. $10 \mathrm{~s} .6 d$.

GROTE'S (George) History of Greece. From the Earliest Times to the close of the generation contemporary with the desth of Alexander the Great. Fourth Edition. Maps. S vols. Sro. 112s.

- Prato, and the other Companions of Socrates. : Vols. Sro.

(Mrs.) Memoir of Ary Scheffer. Post Sro. S\&. Gl.

Collected Papers. Sro. 10s. 6 1 .

GUIZOT's (M.) Meditations on Christianity. Containing 1. Nateral problems. 2. Cmpistian Dogmas. 3 The Supersateral. 4. LiMits of SCiEACE. 5. Revelatios. 6. Isspipation of Hols Schiptere. 7. God ACcordisg to the Bible. S. Jests Cirist according to the Gospels. Post 8vo. 9s. 6d.

HALLAN'S (Henry) Constitutional History of England, from the Accession of Henry the Seventh to the Death of George the Second. Soventh Edition. 3 Yols. 8vo. 30s.

History of Europe during the Middle Ages. Tenth Edition. 3 Vols. 8 vo. 30s.

Literary History of Europe, during the 15th, 16th and 17 th Centuries. Fourth Edition. 3 Vols. 8vo. 36s.

Literary Esạ̧s and Charactere. Fcap. 8ro. 2s.

Historical Works. Containing History of England, - Middle Ages of Europe,-Literary History of Europe. 10 Vols. Post Sro. 6s each.

(Arthor) Remains; in Verse and Prose. With Freface, Memoir, and Portrait. Fcap.Svo. 7s.6d.

HAMILTON'S (James) Wanderings in North Africa. Post Sro. 12s. HART'S ARMYY LIST. (Quarterly and Annually.) 8ro. 10s.6d. and $21 s$ each.

HANNAH'S (Rev. Dr.) Bampton Lectures for 1863; the Dirine and Haman Eiements in Holy Scripture. 8vo. 10s. 6d.

HAY'S (J. H. Dromarond) Western Barbary, its wild Tribes and savage Animals. Post 8 vo. $2 s$.

HFAD'S (Sir Francis) Horse and his Rider. Woodcuts. Post 8ro. Fs. Rapid Journeys across the Pampas. Post 8vo. 2s.

Bubbles from the Brunnen of Nassau. 16mo. 5 s.

Emigrant. Fcap. 8ro. 2s. $6 d$.

Stokers and Pokers; or, N.-Western Railway. Post

Svo. $2 s$.

Fortnight in Ireland. Map. 8ro. 12s. (SIs EDarox) Shall and Will; or, Future Auxiliary

Verbs. Fcap.8ro. 4 . 
HAND-BOOK-TRAVEL-TALK. English, Germn, Freneh, : $: 14$ Italian. 1Smo. $3 s, 6 d$.

NORTII GERMANY, IIOLLAND, BELGIU, an! the Hhine to Switzerland. Map. Post Svo. 10s.

KNAPSACK GUIDE TO BELGIII ANT) TIIE RHINE. Post Svo. (In the Piess.)

SOUTH GERMANY, Bavaria, Austria, Styria, Salzberg, the Austrian and Bararian Alpe, the Tyrn', IJungary, and the Danube, from Ulm to the Black Sea. Map. P'ost $8 \mathrm{w} .10 \mathrm{~s}$.

KNAPSACK GLIDE TO THE TYROM. POA sro. (In the Priss.)

FAINTING. German, Flemish, ani Dutch School. Edited by Dr. WaAges. Wondents. 2 Vols. Post svo. 24 s.

LIVIS OF THIS EARLY FLEMISII PAIXTERS,

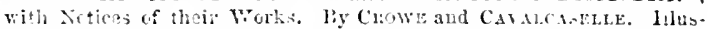
trations. I'ost sro. $12 s$.

SWITZEILAND, Ains of Saroy, and Piedwont. Mapj. I'ost Sro. 9 s.

swo. 5s.

KNADSACK GLIDE TO SWTTEELLAN]). Post

FRANCE, Normandy, Brittany, the Freneh $\Lambda l_{\mathrm{I}} \mathrm{s}$, the Rivers Loire. Seine, lihone, and Garonne, iduphine, l'rovence, and the I'yrenees. Maps. l'ost Gro. I0s.

FNAPAACK GUDE TO FRANCE. POS swo. ( Wia the Press.)

PAlis and its linvirons. Map. Post 8ro. 5.3.

SPAIN, Andalusia, lionda, Granada, Valencia, Catalonia, Gallicia, Arragon, and Navarre. Maps. 2 Y'uls. Post 8 ro. 30 s.

PORTCGAl, Lissox, \&e. Map. l'ost 8ro.

NOR'II I'LALY, l'iectmont, higuria, Venetia,

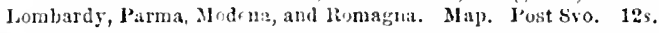

CENTRAL ITALY, Jueca, 'I'useany, Florence, 'lhe Marches, Umbria, and the l'atrimmy of st. l'etr.r. Map. J'ost sov. 10

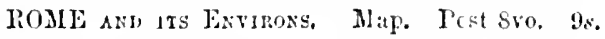

SOUTII ITALY, T'wo Sicilies, Naples, I'ompeij, Herculaneurn, snd Vesuvins. Map. Post 8 vo. 10 s.

KNAISACK GUIUE TO ITALY. Po-t Sro. tis.

SIClIS, I'atermo, Messina, Catania, Syrarue, Ltua,

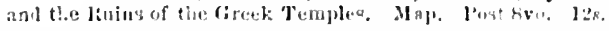

PAINTIXG. The Italian Sclonols. From the fieman

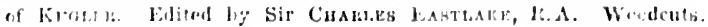

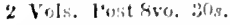

JIVEA OF 'TIE BARLY ITALAN J'AINTER,

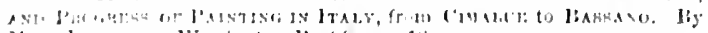

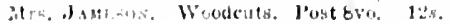


IIAND-BOOK-TICTUNARY OF ITALIAN PAINTER, By A LADY, ldited by liapu Wulsed. With a Chart. Post $8 v c .63 .6 \dot{u}$. GREECE, the Ioni:n Islands, Albania, Thessaly, and Macedonia. Maps. Host bro. 15s.

TURKEY, Malta, Aria Minor, Constantinople, Amenia, Mesopotamia, Sec. Maps. Past Sro. (In the Press.)

EGYPT, Thebes, the Nile, Alexindria, Cairo, the Prramids, Mount Sinai, \&c. Map. Post Svo. $15 \mathrm{~s}$.

SYRIA \& PALESTINE, Peninsula of Sinai, Edom, and Syrian Desert. Maps, 2 Vols. Post Sro. 21 s. SจO. 248 .

BOHBAY AND MADRAS. Map. 2 Vols. Past NORilli, Map, Poet s\%o, 5s.

DENhARK, swenen and Korwat. Maps. Post Sro. $15 s$. 8vo. 12s.

RUSsia, the Baltic and Finland. Maps. Poat

MODERN LONDOS. A Complete Guide to all tie sights and Objects of Interest in the Hetropolis. Map. 16mo. is. E.t.

WESTMINSTER ABBEY. Woodcuts. 16mo. $1 s$.

KENT AND SUSSEX, Canterbury, Dorer, Rams. gate, Sheerness, Rochester, Chatham, Woolwich, Brightcn, Chuchester, Worthing, IIastings, Lewes, Arunde!, \&c. Map. Post Sro. 10 s.

SURPEY, HANTS, Kingston, Croydon, Reigrate, Guildford, Wincliester. Southanpton, Purtsmouth, and Isle of Wistr. Maps. Post 8vo. $7 s .6 d$.

BERKS, BUCKS, AND OXON, Windsor, Eton, Peading, Aylesbury, Uxbidge. Wyrombe, Henley, the City and Lniversity of Oxford, and the Descent of the Thames to II aidenbead aud Windsor. Map. Post Svo. 7s, 6l.

WILTS, DORSET, AND SOJIERSET, Salisbury, Clippewham. Weymouth, Sherborne, Wells, Bath, Bristol, Taunton, sec. Map. Post 8ro. 7s, $6 d$.

DEVON AND CORNWALL, Exeter, Ilfracombe, Linton, Sidmouth, Dawlish, 'Teignmouth, Plymoutb, Devoupnrt, 'Torquay, Launceston, Truro, Peuzance, Falmoutb, \&c. Maps. Post Sro. $7 s . \dot{6} d$.

NORTH AND SOUTH WALES, Bangor, Carnqroon, Peaumaris, Snowdon. Conway, Menai Straits. Carmarthrn, Pembroke, Tenby, Swansea, The Wye, idc. Maps. 2 Vols. Pust Sro. $12 s$.

CATHEDRALS OF ENGLAND--Southern Divicion, Winchestar, Salisbury, Exeter, Wells, Chichester, Rochester, Canterbury. With 110 Illustrations. 2 Yols. Crown Svo, 21s.

CATHEDRALS OF ENGLAXD-Eastern Dirision, Oxford, Petertrmongh. Nonwich, Ely, and Lincoln. With 90 llustrations. Crown Sro. 18 s.

CATHEDRALS OF EXGLAND-Western Divi. sion, Bristol, Gioucester, Her ford, Worcester, and Lichubld. With 50 1llnstrations. Cruwa Svo. 1 bse.

FABILIAR QUOTATIONS. From English Authors.

Third Edition. Fcap. Svo. Es. 


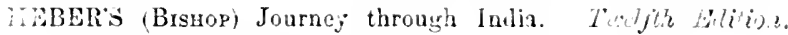
2 Vols. Post sro. is.

Poetical Horks. Sixth Edition. Portriat. Finp. 8vo. 6.

IIRropoTUS. A New English Verion. Elited, with Notes und Essays, historical, ethugraphical, and geographical. By is..1i.

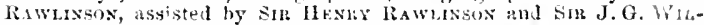

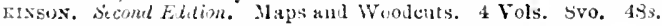

Messer (Rev. Dr.). Sunday-Its Origin, Iistory, and Preacia

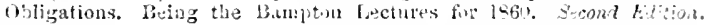
sw. 16 s.

HICKMAN'S (Wyr) 'Treatise on the Law and Pratice of xyav? Courts-Martial. Evo. 10s.6\%.

YILT.ARD' (G. S.) Six Months in Italy. 2 Yols. Post 8vo. Yo.

HOLLW. IY (J. G.) Month in Norway. Ecap. Ero. 2.

nONEY BEE (The). In lang. by lier. Thonas Janes. Reprnted irom the "Quarterly leview." Falp. ovo. 1 s.

JoOk's (Desi) Church Dietioniry. Vinth Edition. 8vo, lis.

- ('Turodora) Life. By J. G. I.ucknation. Reprinted from ti:s "Qurterly lieview." Fcap.sw, 1:.

MnOK ER'S (Dr. J. D.) Ilimalayn Jommals; or, Notes of an Crienial

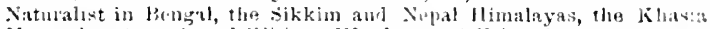

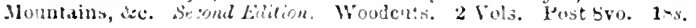

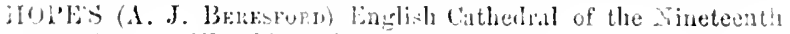

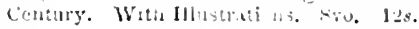

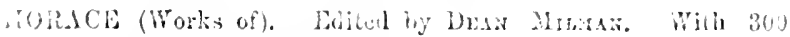
Wordcuts. Crowusvo. 21s.

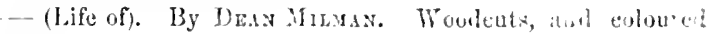
liosders. 8vo. 9s.

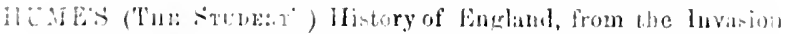

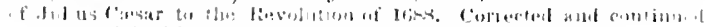

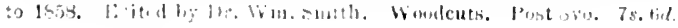

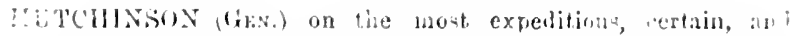

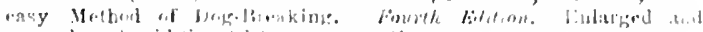

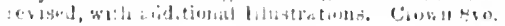

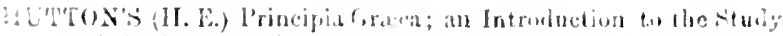

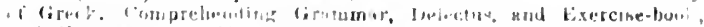

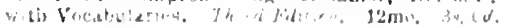


IIOAE AND COLONIAL LIBRARY. A Series of Works adapted for all circles anI classes of Readers, having been selected fin tleir acknowledyed interest and ability of the Authors. Post 8vo. Published at $2 s$. and $3 s .6 a$. each, and arranged uuder two distiretive heads as follows:-

\section{CLASS 2.}

HISTORY, BIOCPAPHY. AND HISTORIC TALES.

1. SIEGE OF GIBRAITAR, TY JotX DENKWATEF. Es.

¿. THE AMBER-WITCII. By LADX DUFF GORDON. 2s.

¿.ROMWELL AND BUXYAX. By ROBERT Sottritit. 25.

4. LIFE OES SIR FRANCIN DR.L ISE. BY JOHN Ba Row, -s.

5. UAMPAIGNS AT WASIINGTON. BY IRE. G. R. GLEIG. 2\%.

c. THE FRENCII IN ALGIEIS. By Ladr Duke Gomos. 2s.

7. TIIE FALL OF THE JESUITS. $2 s$.

S. LIVONIAN TALES. ¿s.

๑. LIFE OF CONDE. BY LORD ME Hox. Os. $6 d$.

10. SALES BRIGALE. Hy ZLV. G. K. GLEIG. 2 $s$.
11. TIIE SIEGES OF YIENNA. by Lond Eldes MRre. $2 s$.

12. THE WAYSIDE CROSS. BY CAPT. Milmax. $2 s$.

13. KKTTIES OF GERMAN LIFE. I3v Sir A. Gordon. 3s. $6 d$.

14. TIE BATTLE OF WATERLOO. By Rev. G. R. Gleig. 3s.6d.

15. ACTOHIOGLAPII OF STEF. FENS. 2s.

16. TIE BRITISII POETS. MY Thonas Campbeli. $3 s .6 d$.

17. IISTORICAL ESSAYS. BY LORD ilahon. 3s. Cd.

13. LIFE OF LORD CLIVE. BF liev. G. I. Gleig. 3s. Gd.

19. NORTH - WESTERN RAILWAY. By SIR F. H. HEAD. 2v.

20. Life of MUNRo. Dy Ref. G. R. Gleia. 3s. 6d.

\section{CIESS P.}

\section{VOYAGES, TRAVELS, AND ADVENTURES.}

1. BIBLE IN SPAIA. HYGEOEGE BOrEotv. 3s. 6 .

2. GIPSIES or SPAIN. BF GEORaN Borrow. 3s.6a.

U 4. JOURNALS IN INDIA. BE Bishop Ilemigr. 2 Yols. $7 s$.

J. TRAYELS TNTHE IIOL T LAND. By IRBi and MANGLES. 2s.

2. IIOROCCO AND TIE MOORS. Ly J. DeUMano HAY, $2 s$.

7. I. TTERTS THOM THE BALTIC. Bद a LADY. 2s.

S. NEW SOUTH WALES. By MIR. MZEEDITE. 23.

9. TIIE WEST INDIES. By N. G. LEWIE, $2 s$.

1). SKETCIES OF PERSIA. By Sir Joma Malcolm. 3s. Gi.

11. MEMOIRS OF FATHLR RIPA. 28.

12. 13. TYPEE AXI OXOO. PY Hermans MerVILLE. 2 Vols. Ts.

11. MISSIONARY LIFE IN CANADA. Bg REV.J. ABвotT. 2s.

15. LETTERS FROM MADRAS. Pr a LADY. 2s.

:3. IIITILAND SPORTS, BY Ciratiles St. JohN. $3 s .6 a$.

17. PAMPAS JOURNEYS. BY SIR F. B. HEAD. "us.

18 GATHERINGS FROM SPAIN. By Richard ford, 3s. $6 u$.

25. TUE RIVER AMAZON. BY W. H. EDWARDB, 2s.

20. IANNEIS \& CUSTOMS OF IXDIA. BrREY. C. ACLAND. $2 s$.

21. $\triangle D Y E N T U R E S$ IN MEXICO. By G. F. Ruxtos. 3s. 6?.

22. PORTUGAL AND FALLICIA. By Lord Carnarvos. 3s. $6 d$.

23. BUSH LIFE IN AUSTRALIA. By Rev. H. W. Ha ganth. $2 s$.

24. TIE LIBIAN DESERT. By BAYLE St. JOHN. 2s.

25. SIERPA LEONE. By a LADT. $3 ? .6 d$. 
IRBY AND MAYGLES' T'ravels in Egypt, Tubie, Syria, and the Holy Land. Post Sro. 2s.

J.AAES' (Rev. Thomas) Fables of .Esop. A New 'Trutuslation, with

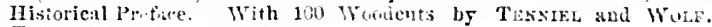
Thiriy-ighth Thousani. P'ust swo. 2us. bia.

JAMESON'S (Mrs.) Lives of the Early Italian Painters, from

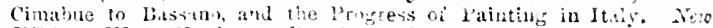
Edition. With Woudents. Dustero. 12s.

JESSES (LDwari) Gleanings in Nutural History. Eighth Lultion. Fep. 8ro. 6s.

johissor's (Dr. Samuzh) Life. By James Boswell. Includin'

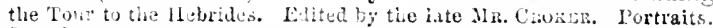
loysalso. 1us.

Livos of the most cminent Finglish Peetz. Edites?

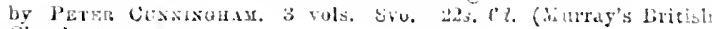
(litsico.)

JOURAAL OF A TATURALIST'. Woodeds. Post SPo. 9s. Gi.

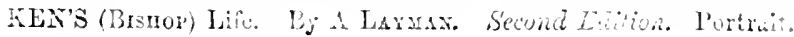
2 Vols, bro. $1:$.

- Disposition of the Apstles' Creer. Extracted from hi "iractice of bivine Live." leap. 1s.6u.

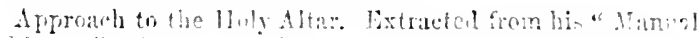

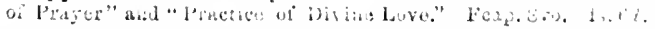

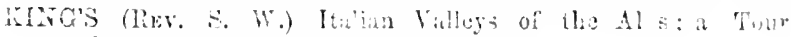

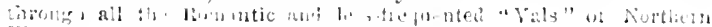

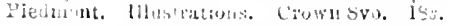

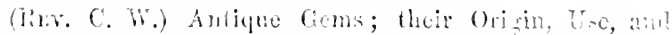

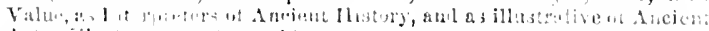

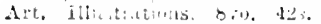

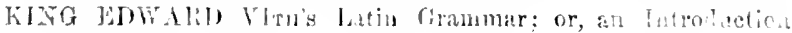

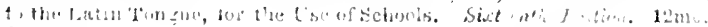
3s. bil.

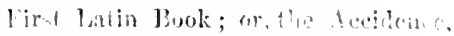

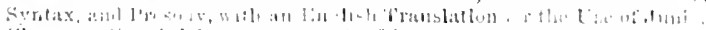

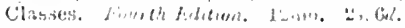

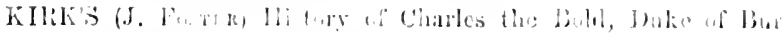

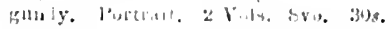

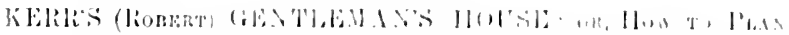

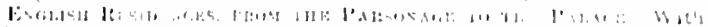

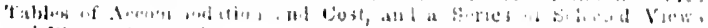
a:1! Plans, sin, 21.5 
KUCLERS Italian Schools of Painting. Editer, with Notes, by Sir Charles Eastlake. Third Eidition. Woodcuts. 2 Vols. Post 8vo. $30 s$.

German, Dutch, and Flemish Schools of Painting. Edited, with Notas, by Dr. WAAGEx. Eecend Elition. Woodeuts. 2 Vols. Po:t Svo. 24:.

J.A TGUAGE (The Exalisul. A Series of Lectures. By Caroril: P. Marsu. Edited, with additional Chapiers aud Notes, ly W T. Amy Ir. Li. D. Post 8ro. is. 6\%.

I.A'PIN GRAMMAR (King EDward VIth's). For the Use of Schools. Sisterinth Eitition. 12mo. 3s.6d.

First Book (King Eoward VIth's); or, the Accidence, Syntax, and Prosody, with English Translation for Junior Classes. Fourtin Edition. 12mo. 2s. 6d.

AYARD'S (A. H.) Ninereh and its Remains. Being a Nar. rative of Researches and Discoveries amidst the Ruins of Assyria. With an Account of the Chaldean Christians of Kurdistan; the Yezedis, or Devil-worshippers; and an Enquiry into the Manners and Arts of the Ancient Assyrians. Sixth Edition. Plates and Woodents. 2 Vols. 8vo. $36 s$.

Nineveh and Babylon: being the Result of a Second Expedition to Assyria. Fourteenth Thousand. Plates Sro. 21s. Or Fine Priper, 2 Yols. 8vo. 3r's.

Popular Account of Nineveh. 15th Edition. With Woodeuts. Post 8 vo. 5s.

LEAKE'S (COL.) Topography of Athens, with Remarks on its Antiquities. Secoma Falition. Plates. 2 Vois. Sro. 30s.

- Travels in Northern Greece. MLaps. 4 Yois. 8vo. $60 s$.

Disputed Questions of Ancient Geogrephy. Mar. 8vo. $6 s .6 d$.

Numismata Irellenica, and Supplement. Completing, vescriptive Catalngue of Twelve Thomsand Greck Coins, with Notes Geographical and IIistnrical. With Map and Appendix. 4t.. $63 \mathrm{~s}$.

Peleponnesiaca. Sro. 15s.

Dagradation of Science in Engrland. 8vo. 3s. $6 i$.

LSLIES (C. R.) Handhook for Young Painters. With Ilustra. tions. Post Svo. 10s. 6a.

Autobiographical Pecollections, with Selections: from his Correspondence. Edited by Ton TAYLor. Portrat. 2 Vols. Po:t svo. 1ss.

Life of Sir Joshua Reynolds. With an Acconnt of his Woiks, and a Sketch of his Cotemporaries. BF ToM Tarios. l!lustrations. 2 Vols. \&ro.

JAERES FROII THE SHORES OF TIIE BALTYC. BY a CATY. Post 8 vo. $2 s$.

Manras. By a Lany. Post $3 \mathrm{rr}$. 23.

Sirra Leoks lyy a Ladr. Ellited by the Jumarafe Mire. Nontox. Post Svo. 3s. 6d. 
HEWIS' (SIR G. C.) Lisay on the Government of Dependencies. Sro. 1:s.

Glossary of Frovineial Words used in Herefordhire ant some of the adjoining cousties. 12uro. 4s.6al.

(iI. G.) Journal of a liesidence among the Negroes in the West Indies. Post nro. $2 s$.

LIDIELLAS (DEAN) IIistory of liome. From the Garliest 'limes to the Establishment of the Lmpirs. With the llistory of Lit:ratu:." and Art. 2 Yols. $8 \%$. 26.

Student's Hirtory of Rone. Abridtrel from the abore Work. 2ath Thuosemi. With Woudeuts. l'ust Sro. is.6\%.

LINDSAY's (Lony) hives of the Lindsays; or, a Memoil of the llouses of Crawtud and Ralearres. With Extracts from Untial Papers and Personal Niaratuves. Second Edition. 3 Vols. Sro. 24 s.

Report of the Claim of $J_{\text {atmes, }}$ Earl of Crawfuri and Balcarres, to the Griginal Juketom of Montruse, created in 1185 Folio, 15.

Scepticisnt; a letrogressive Movement in Theology and linl s thy. bro. 9.

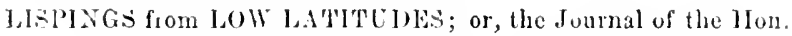

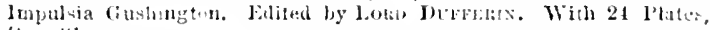
4to. $21 \mathrm{~s}$.

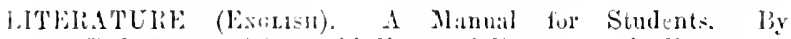

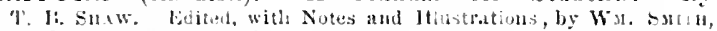

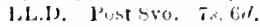

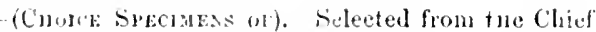

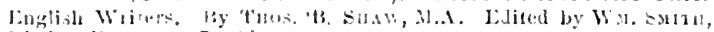
1.L.1. P'ost 8*w. Ts. 6id.

LITRLE ARTHUR'S IISTORY OF EXGLAND. By LAH Caldcott. 1:06h Therusend. With 20 Woodents. Teap. 8vo. 2s. 6d.

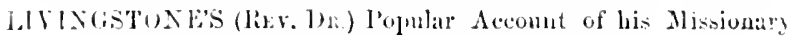

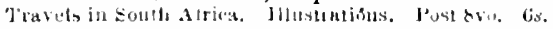

Narrative of an lexpedition to the $/$ mulere and its Tributaries; and of the iliscosery of bakes Stirwa and Nydsat.

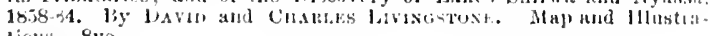
tions. 8 vo.

IIYONIAN TAJES. By the Author of "Letters from the lablic." P'ust 8vo. 22.

LOClildRT'S (J. G.) Ancient Spruinh Ballads. Jlintorical and Jimaunice Transhated, with Nones. Lllustrated Eiltion. 4to. 21s. Or,

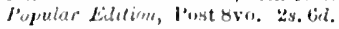

Jife of Robert Burun. Fifth Eelition. Feap. 8vo. 39.

LoNI)GX's (Brolol or) Dangers and sifeguarel of Moden

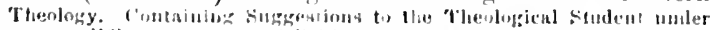

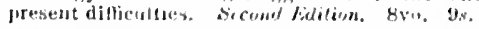

(1) UDON'S (Mks.) Inatructions in Gardening for Iadicm. With

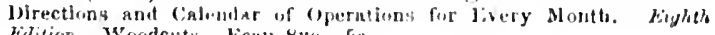
fidition. Woodents. Fechy, sro. 54. 
LUCAS' (SAMCEL) Sceularia; or, Surreys on the Main Strean of llistory. Sro. $12 s$.

LUCKNOW: a Lady's Diary of the Siegre. Fourth Thousand. Feap. Sro. $4 s .6 d$.

3.Y.JLL'S (Sir Charles) Elements of Geology; or, the Ancicnt Changes of the Earth an! its Inlabbitants consilered as illustrative of Geology. Sixth Elition. Woodcuts. Sro. $18 s$.

Geological Eridenees of the Antiquity of Man. Tium Elition. Illustrations. Sro. 14.

IXTTELTON's (Loni) Ephemera. Post sro. 10s. 6il.

ETTTON' (Sir Edward Dulyer) Toems. Ter Elition. Revised. Post 8:0. 10.

MAHON'S (IORD) History of England, from the Peace of Utrecht in the Peace of Versailles. 1713-83. Litrary Edition. 7 Vols. 8ro. 93s. Fopular Edition, 7 Yols. Pont Sro. Sos.

"Forty-Five;" a Narrative of the Rebellion in Scotland. Post Sro. 3s.

Iistory of British India fiom its Origin till the Peace of 17S3. Post Sro. 3s. Cd.

Spain under Charles the Second; 1690 to 1700. Seconil Eation. Post 8ro. 6s. 6a.

Life of William Pitt, with Extracts from his MS. Papers. Second Eilition. Portraits. 4 Vuls. Post 8 vo. $42 s$.

Conde, surnamed tlie Great. Pcst 8vo. 3.s. 6d.

Belisarius. Second Edition. Post 8vo. 103.6d.

Historical and Critical Essays. Post 3ro. 3s. 6a.

Miscellanics. Second Elition. Post Sro. 5s. 6rl.

Story of Joan of Are. Fenp. 3ro. 1s.

Addresses. Fcap. Sro. 1s.

MeCLINTOCK'S (CAFT. SiR F. L.) Narrative of the Discorery of the Fate of Sir John Franllin and his Companions in the Aretic Seas.

Twelfth Thousand. Illnstratious. Sro. 1ês.

IICULLOCH'S (J. R.) Collected Edition of Ricardo's Political Woris. With Notes and Memoir. Sreml Lation. Sro. $16 s$.

MACDOUGALE (CoL.) On MLodem Warfare as Infuenced by Modern Artiliery. Mith Plaus, Post Sto. 123.

IIAINE (H. Suxwer) On Ancient Law: its Connection with the Early History of Societs, and its Relation to Norlern Ileas. Sccond Edition. Sro. 12 s.

IALCOIAS'S (SIR JoAn) Sketches of Persia. Third Edition. Post Bro. Es. 6 .

IANSEL (Rev. H. I.) Limits of Religious Thought Examined.

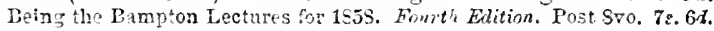

-INNSFIELD (Sin WILLIA) On the Introduction of a Gold rumency in* India: a Conrilytion to the Literatare of Political Ec noms. Sro. 35.6a. 
MANTELL'S (GIDEoN A.) Thonghts on Animaleules; or, the Invisible Worlh, as revealed by the Microscope. Secont Edition. I'lates. $16 \mathrm{mo}, 6 s$.

MANUAL OF SCIENTIFIC ENQUIRY, Preparcd for the Use of Officers and Travellers. Br ratious Writers. Ellitel hy sir I. F. Jlerscurte and Rev. Ii. Maisi. Third Fation. Maps. Post Evo. 9s. (Fublished by order of the Lords of the Admiraliy.)

MARKHAN'S (Mrs.) History of England. From the First Invasion by the Ramans, down to the tourteenth year of Queen Victoria's Reign, 156th Edition. Wondents. 12u\%. 6\%.

History of France. From the Conquest by the Gauls, to the Death of Louis Philippe. Sixtith Eilition. Woodents. 12mo. 6s.

History of Germany. From the Inrasion by MLarius, to the present tine. Fijtuth Lidition. Woodcuts. 12mo. Es.

History of Grecee. From the Barlicst Times to the Roman Congueit. lig Dr. Wr. Smitu. Wooderts. 1/5mo. 3. $6 d$.

History of Ione. From the Earliest Times to the Establislumint of the Empire. Ry Dr. Wr. Sistis. Woodeuts. 16mo. 3s. Gi .

(Clasexts R.) Travels in Peru and India, for the purpose of collectin: Cinelura l'ataty, and introhtrcing bark into India. Maps and Intastmanis. Evo, i6:

MARKLAND'S (T. H.) Reverence due to Holy Places. Thirk Edition. Fcap. 8ro. 2\%.

MARTYAT'S (JuspI) History of Molem and Nedimval Fotter: and Porcelain. Witin is I"scriptions of the Manufactum. Seconis Elition. Plates and Wirouts. 8vo. S1s.tid.

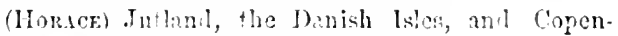
largen. Illistrations. 2 Vidk. P'ost S6r. 21s.

vols. pinteron ans.

MATTHIN'S (AcGustus) Greek Grammar for Schools. Ahrilged

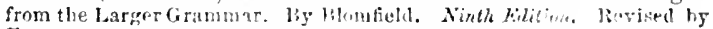
EDwards. 1 1mo. 3s.

M.AUREI'S (Julfs) Bsay on the Character, Aetions, am! Writinga

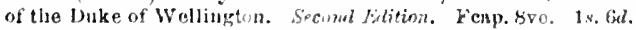

MAXIMS AND IINTS on Angling and Chere by lizmart Press. Woodcuts. 12mon. 1 s.

MAYXES (R. C.) Folir Yes in British Columbia and Y:tn-

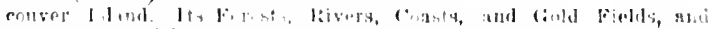

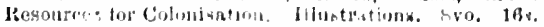

MELVIfJli:s (Hrimans) Type and hinoo; or, Alrentur

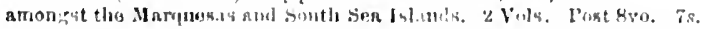

MLREDITIS'S (Mra. Cunurris) Notes and Slietches of Now South Wale. H. poist swo. 2 s. 
NESSIAH (THA): A Narrative of the Life, Trayel, Dears, lic surrection, and Ascension of our Blassed lord Br A labm Anthor of the "Life of Binop ken." Mal. Sro. 1sis.

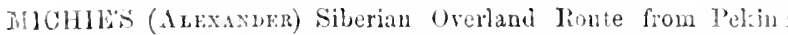

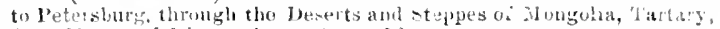
cic. Naps and Ithitrations. Sro. 16\%.

Fillis (Anthus) India in 1853; A Summary of the Fxisting $\Lambda$ Aministration. Second Edition. Map. Sro. 10s.6\%.

(Rev. Jonx) Three Monthe' liesidence ats Nalolus. wit: su Accunst of the Nodern Samaritans lilustrationc. Post Svo. 10s. is?

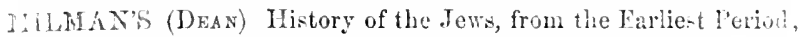

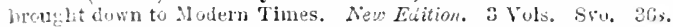

Christianity, from the Birth of Christ to the

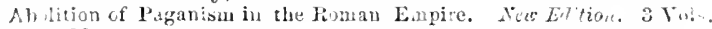
S.0. 36 .

Latin Christianity; including that of the Popss to the Pontificate of Nicholas V. New Elition. 9 Vols. Sro Sts.

- Character and Conduct of the Apostles considered 9.3 sn Evidenee of Christianity. 8ro. 10s. $6 d$.

- Life and Works of Horace. With 300 Woodcuts. ¿Vols. Crown sro. 30s.

- Poetical Works. Plates. 3 Vols. Feap. 8ro. 13 s.

- Fall of Jerusalem. Fuap. 8ro. 1 s.

(Cart. E. A.) Wayside Cross. A Tale of the Carlist War. Post 8ro. 2s.

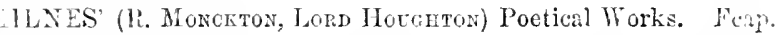
850. 6.

II IDERN DOMESTIC COOKERY. Founded on Principles of Lconomy and Practical knowled te and adapted for Private Families. New Edition. Woodcuts. Fcap. Sro. 5 s.

MOCliE's (Thomas) Life and Letters of Lord Byron. Plates. 6 Vols. Fcap. 8ro. $18 s$.

- Life and I.etters of Lord Byron. Portraits. Royal sro. 6.

J10'LLE'S (J. L.) History of the United Netherlands: from the Jeatl: of William the silent to the Syuod of Dort. Embracing the: English-Dutch struggle against Spain; and a detailed Account of the Spenish Armada. Portraits. 2 Vols. 8vo. 30s.

3 JUHOT's (HFnri) Siam, Cambojia, and Lao; a Narrative of Tlavels and Discoveries. Illustrations. 2 rols, Sro. 3:s.

HOZLEY'S (Rer. J. B.) Treatise on Predestination. Sro. 14s. Primitive Doctrine of Baptismal Regeneration. 8ro. $7 s .6 \mathrm{l}$. 
MUNDY's (Genfrar) Pen and Pencil Sketehes in India. Third Edition. Slates. Post bro. Ts, Cd.

(Amajkal) Account of the Italian lievolution, with

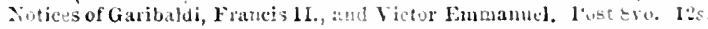

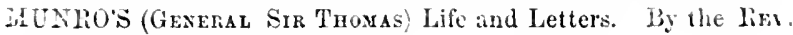
G. fi. Gleig. Pust Svo. 2s. Gel.

MURCHISON'S (SIR Ronerice) Rusia in Europe and the L Tal Monntans. With Colonred Mtep, Plates, sections, \&c. 2 Vols. liogal 4 to.

Siluria; or, a History of the Ollest liocks cou.

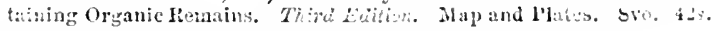

\section{MURRAY'S RAILWAY READING. Containing:-}

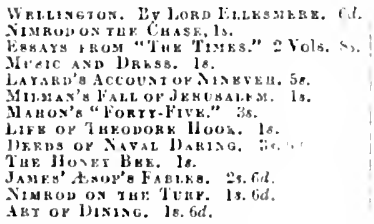

MUSIC AND DRESS. By a Lawr. Reprinted fom the "(luarterl! licuew." Ecap. sro. 1 s.

NAPlEli's (D) Wx) Euglish Battles and Sieges of the Peninsular War. Third Vilicion. L'ortrait. I'ost Evo. 10s.6\%.

Life and Letters. Edited W. II. A. Buver, M.I'. rurtraits. 2 Vols. Crown bvo. 2y.t.

Jife of General Sir Chirles Napier: chiefi" drived Irom his Journats and Letters. Sicomi I.dilien. I'ustraits. a Vuls. I'osit sro. 4s's.

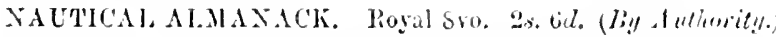

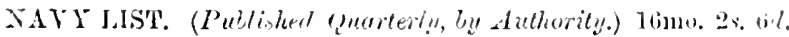

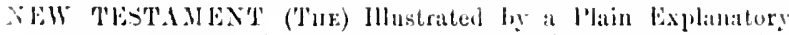

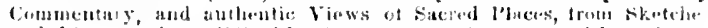

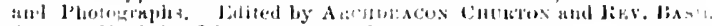

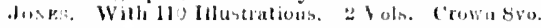

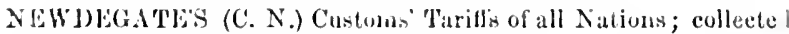
and arrasized uje to the year 15is. $420.30 s$.

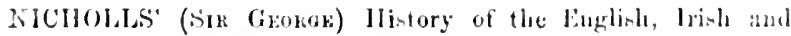
scoled loor liwh. A Vis. Svo.

(lice. II. (i.) Ilistorical Aecount of the fiorest of 11.311. Woodchts, \&c. I'obl 8vo. 10y.6il.

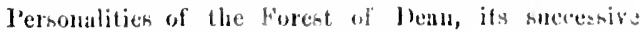

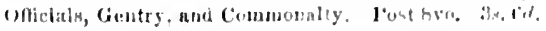


NICOLAS' (Sir HankIs) Historic Peerage of England. Exhi. biting tho Oririu, bescent, and l'resent state of every Title of Peerare which has existed in this Conntry since the Conquest. By Wilman Counthore. Sro. 30:.

NIMROD On the Chace-The Turf-and The Road. Reprinted from the "Quarterly Review." Woodent. Feap. 8ro. 3s.6e.

O'CONNOR'S (R.) Field Sports of France; or, Innting, Shooting, and Fishing on the Continent. Woodeuts. 12mo. 7s.6x.

OXENIMAN'S (REv. W.) Anglish Yotes for Latin Elegiacs ; designed for early Proficients in the Art of Latin Versification, with Prefatory Rules of Composition iu Elegiac Metre. Fonoth Edition. 12mo. 3s.6d.

PARIS' (Dr.) Philosophy in Sport made Science in Earnest; or, the First P'rinciples of Natural Plailnsophy inculcated by aid of the Tors and Sports of Youth. Ninth Elition. Woodcuts. Post Sro. $7 s, 6 d$.

PREL's (Sir Robert) Memoirs. Euited by Fard Stanhope

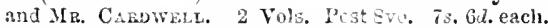

PENN'S (RICHARD) Maxims and Hints for an Angler and Chessplayer. New Edition. Woodcuts. Feap.Sro. 1s.

PENROSE'S (F. C.) Principles of A thenian Arehitecture, and the Optical Rehements exhibited in the Construction of the Ancient Buildings at Athens, from a survey. With 10 Plates. Folio. 5l.5s.

PERCY'S (JoHN, MID.) Metallury of Iron and Stecl; or, the Art of Extracting dletais from theil ores and adapting then to various purposes of Xianuacture. Intustrations. Sro. $42 s$.

PhILliPP (Charles Spencer Marii) On Jurisprudence. 8vo. $12 s$.

PHILLIPS' (fonis) Miemoirs of Whiliam Smith, the Croologist. Portrait. Sro. $7 s .63$.

Geclogy of Yorkshire, The Coast, and Limestone District. Plates, 4ts. Part I., 2ns.-Part II., 30s.

Rivers, Mrountains, and Sea Coast of Yorkshire. With Essays on the Climate, Sconery, and Arcient Inhabitants. Second Edition, Plates. Sro. 15s.

PHillporT'S (Bisrop) Letters to the late Charles Butler, on the Theological parts of his "llook of the Roman Catholic Church;" witli Remarks on certain Works of Dr. Il ilner and Dr, Lingard, and on some parts of the Evidenco of Wr. Doyle. Second Edition. Svo, 16s.

POPE'S (Alexander) Life and Works. 1 Tew Edition. Con. taining nearly 590 mpublinbed Letters. Edited with a Nerv LIFv, Intruductions and tiote.s. By Rev. Whitwell Elwir. Portraits. Svo. (In the Press.)

PORTER'S (Rev. J. L.) Five Years in Damaseus. With Travels to Palmyra, Lebanon and other Scriptme Sites. Mlap and Woodcuts. 2 Vois. Post 8 vo. $21 s$.

Handbook for Syria and Palestine : includingan A ceount of the Gergraphy, Hintnry, Antiguities, and Inlazitauts of these Countries, the Prinsula of Sinai, Edom, and the Strian Desert. Maps. 2 Vols. Post 87o. 24s. 
PRAYER-BOOK (The Tllustrated), with 1000 Ilutrations of Bor-

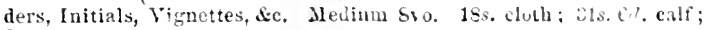
$3 \mathrm{c}$ s. morrucco.

FRECEPTS FOR THE CONDICT OF LIFE. Extracted from the icriptures. Sicmel Fitition. Fonp. Sro. 1 s.

PUSS IN BOOTS. With 12 Jlusuations By OtTo SPEoktri. Culoured, 16mo. 2s. ca.

QUARTERT REVEA (THe). Sro. es.

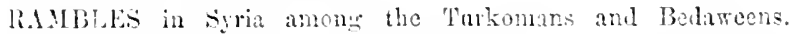
Pest sw. 1(c. 6l.

lidwlixsox's (Rev. Grokan) Herolotus. A New Finglish

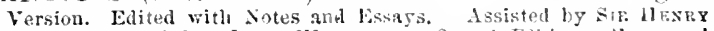

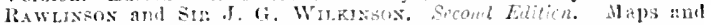
Wooncut, 4 Viols. 3ro. 4 s.

- IIistorienl lvidences of the truth of the Seripture Reconds stated anew. Secombletilina. Sro. 14k.

Five fireat Monachics of the Ancient Worlh.

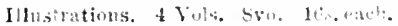

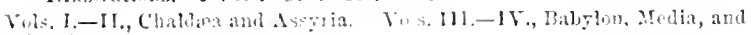
Pertia.

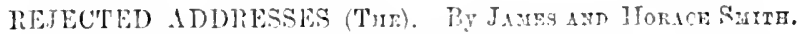

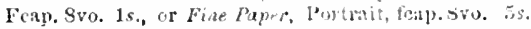

likxylas (1). F.) British Irms in Peking. 1s60; Tagnsina, ro6.2. Pest Sro. Jis.

P'kin and the Pekines: Narrative of :

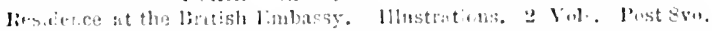

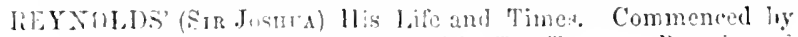

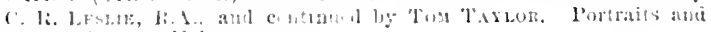

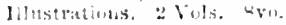

HICARJu's (DArin) Political Worls. With a Notice of his

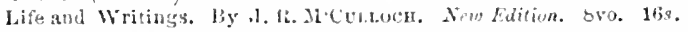

PIPA'S (Fatnen) Nemoirs during Thirteen Years' Residence at the

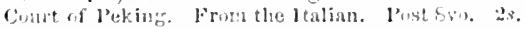

RoBEDTSON'S (CANor) Bli-tory of the Christian Chureh, from

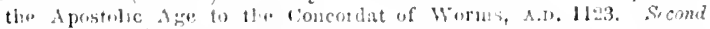
Exlition. :3 rols. Swo. E\&s.

JoBussox's (Jiry. 1)n.) Billical lesearches in the fioly dand.

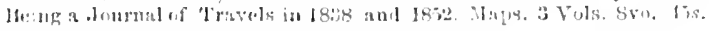

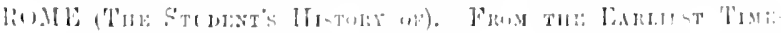

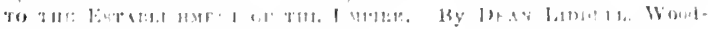

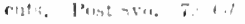

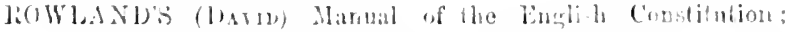

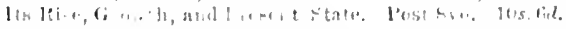

…

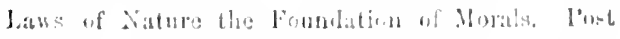

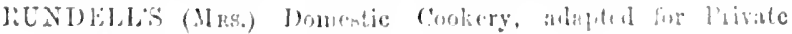

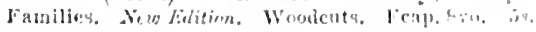




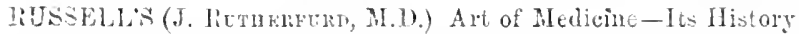
and is llemes. Fertmits. tro. $11 \mathrm{~s}$.

RUXTON'S (Gronge F.) Trapuls in Mexieo: with Aaventures among the Wild 'lrihes and Animals of the Prailies and kock Motntains. Pust bro. 3s. tid.

S.MLA (Sir Robert) Brigade in Afghanistrn. With an Aceonnt of the Defence of Jellahahd. Py Rev. (r. R. Lilmig. Post Sro. "2s.

SANI)HITH'S (Humprir) Siege of Kars. Tust sro. 3. Gal.

COTT'S (G. Ginbert) Secular and Domestic Allitecture, I'lsent and Future. Sechil Luition. Sro. Ss.

- (Master of Balial) University Sermons I'ost sro. Si. Git.

SCliul'E's (G. P.) Geology and Extiuet Tulemoes of Centril France. Second Edition. Ilustrations. Medium Sto. 30s.

SELF-HELP. With Illustrations of Character and Conduct.

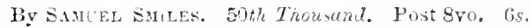

LNIOR'S (N. W.) Suggestions on Ponular Education. Sro. $! s$

SHAFTESBLIiT (Lont Chancellok) ; Memoirs of his Larly Life. With his Letters, \&. liy W. W). Cmmstie. Portrait. Sro. 1us. 6d.

SHAW' (T. B.) Student's Manual of English Literature. 'Edited, with Notes and linstrations, by Lr Wy. Smitr. Pust Svo. is.Gu.

Choiee Specimens of English Literature. Selected from the Chief Lnglish Witers. Ldud 7s. 64 .

SIERRA LEONE: Deseribed in Letters to Frienis at IIome. By A Ladr. Post sro. 3s.6d.

SIMMONS on Court-Martial. 5th Edition. Sro. 11.

SIILFS (SAMCEL) Lives of British Engineers: froril the Earliest Period to the Deatl of Robert Steul $n$ non: with an accutst of their Pincipal Works, and a Hint ry of Inlani Communication in Bridia. Pirtraits and Ilustrations. 3 Vols. Swo. 63 s.

- George and Rolert Steplenson: the Story of their Lives. With Purtraits and (1) Woudeuts. Post Sro. Us.

James Brindley and the Early Engineers. With Portrait and 50 Woodents. Puit Sro. 6i.

Self-Help. With Illustrations of Character and Conduct. Post 5ro. 6s.

Indnstrial Biography : Iron-Workers and Tool Makers. A companion volutute to "selt-1lelp." Post $8 v^{\circ}$. 68.

_- Workmen's Laruings-Sarings-aud Strikes. Feap. sro. 1s. $6 d$.

SOMERVILLE'S (Mary) Physieal Geography. Fifth Eaition. Portrait. Post 8ro. $9 s$.

Connexion of the Fhysieal Seiences. Ninth Edition. Wroodcuts. Post 8 ro. 9s.

SOUTH's (John F.) Houschold Surgery; or, Hints on Lmergen. cies. Seventeenth Thousard. Woodeuts. Fep.Sro. 4s.6?. 
SMITH'S (Dr. Wr.) Dietionary of the Bible; its Antiquities, Fiography, Geography, and Natural llistory. I lustrations. $3 \mathrm{Vilh}$.

8vo. Goss. ciuts. Sro. 4ts.

(114. 3 Vo's. Swo. 51. 15s. 6d.

Biography and Ifythology. Wooksiro. Sis.

Geograply. Woodeuts. 2 Fol.

Classical Dictionary of Mytlology, Biography, an! diengraphy, compiled from the above. With 550 Wonduts. dro. 1s.

Latin-English Dictionary, 3rd Edition. Revised. s.o. 21.

- Smaller Ciassieal Dietionary. Wocdents. Crown ove. 7s. 6 el.

7. $6 u$.

Dietionary of Antiquities. Woodents. Crown Swe. Latin-English_Dictionary, 12mo. is. ord.

Jatin-Englisl Vocabuary; for Phadrus, crenciu-

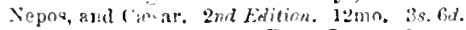

Lrincipia latina-Part I. I Crammar, Deleche, an?

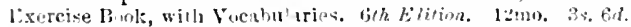

Part II. I Bealing-book of liyilo.

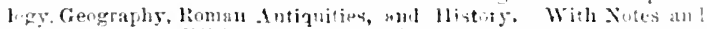

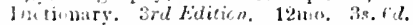

Part III. I Latin Poctry lirul..

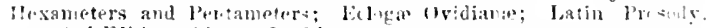

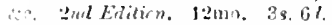

Part IV. Latin Prose Compo:ition.

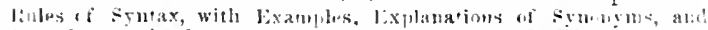

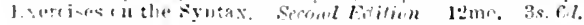

Student's Greek Grammar. By Profesor Crrates. loot m. $79 \%$

$12 \mathrm{mo} .3 *, 6,1$

Latin Grammar. Pet sro. 70 bil.

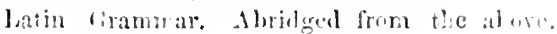

smaller cireck Grammar. Abribrel from curtic: lation. 33. (ist.

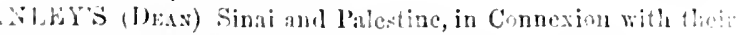
Hision. Map. sso. 1fis.

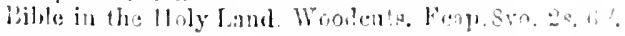

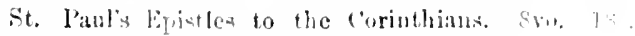
Eastern Ghurch. linny. vo. 12s.

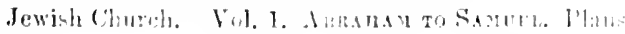
"wn. 14.

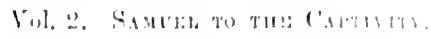

- wo. 1tis

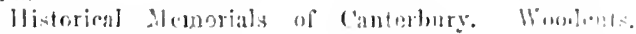

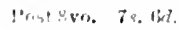

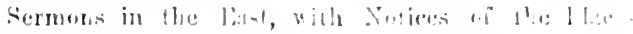

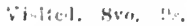

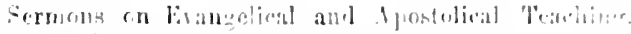

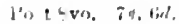

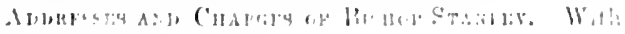

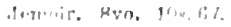


SOUTLEY'S (RoBert) Book of the Chureh. Seventh Edition. Post sro. 7s, ir?.

Lives of Bunyan and Cromwell. Fost 8 ro. $2 \kappa$. SPEClTER:S (Otro) Puss in Boots. With 12 Woodeuts. Square 12mo. 1s. 6d. plain, or 2s. Gi. coloured.

Charmed Roe; or, the Story of the Little Brother aud Sister. Illustrated. 16mo.

ST. JOHNS (Crnanes) Wild Sports and Natural History of the Higliands. Post 8vo. 3s. Ga.

(BArLe) Adrentures in the Libyan Desert and the Oasis of Jupiter Ammon. Woodents. Post svo. $2 s$.

STANHOPES (EARL) Life of William Pit. With Extracts

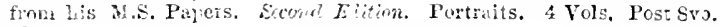
$42 s$.

Misceharies. Second Ledition. Post Sro. 5s. 6d.

STEPHENSON (Georee and lioberr). The Story of their Lives. Dy Same Sulles. With Portraits aud 70 lllustrations. Post Sro. $6 s$.

STLDENT'S HUME. A History of England from the Invasion of Julns Ceesar to the Revolution of 16s8. liy David Huza, and continued to 1S5s. Wroodcuts. Post Sro. is. 6a.

* * A swaller Ilistory of Eugland. 12mo. 3s. Gl.

HISTORY OF FRANCE; from the Earliest Times to the Istahishmint of the Stcond Empire, 1852. Hy W. II. Pealisus, Xi.A. Woudeuts. Post Evo. 7s.6d.

HISTORY OF GREECE ; from the Earliest Times to the Rrman Concilest. With the Hisiory of Literammend Art. By Wr. Sistil, LL.J. Wondents, Crown 8vo. 7s. 6d. (Questions. 2s.) * A smallek Ihisingr ue Geeece. 12mo. 3s. Gd.

HISTORY OF RONE; from the Earliest Times tr. the Lstablishment of the Empire. With the History of Literature

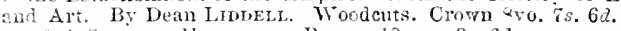

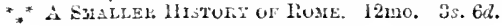

GIBBON; an Epitome of the Hitory of the Decline and Fuil of the R'man Empire. Ly Eoward Gibeos. Inerp'rat. ing the researches of liecent Commentaturs. Woodeuts. P'ost Sro. Ts. 6 ? .

MAXUAL OF AXCIENT GEOGRAPHY. By. Ler. W. L. Levas, M.A. Woodents. Pust Sro. is. $\mathrm{d}$.

WNGLISH LANGUAGE. B̈ Gzorge P. MARST. Post Sro. is, fid.

ENGLISH LITERATURE. By T. B. SHAw, M.A. Post 8vo. 7s.6d.

SPECHMLXS OF ENGLISH LITERATURE. selected from the Chlef Writers. Dy Thomas D. SaAw, H.A. Post svo. Ts. 6il. 
STOTHARD's (Trus.) Life. Witl Personal lieminircelices. Bg Mrs. Bray, With lortrat sal co Wuodeuts. Ito. 21.

STREET'S (G. E.) Gothic Arehitecture in Spain. From Tersonal Observations during sevaral joundegs tinough that cumby. Illus. ilatiulas. Hediun orj.

Brick and Marble Architecture of Italy in the Middle Agres. Plates. 8ro. $21 s$.

SWIFT's (Joxathas) Life. Lcters, Jomnals, and Horks. By Jons Furster. Sro. (Th Irefurution;

SYJIE's (Professon) Principies of Surgery. 5th Edition. Sro. 12.:

TAIT's (BIsnop) Dangers and Fifegurds oi Mlodern Theology. svo. 94.

TAYLOR'S (Inis) Totesfom Jifs. Itap. 8ro. 25.

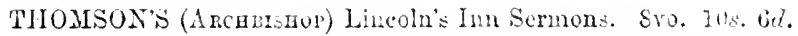

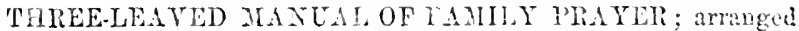
so as to save the ta hilje of haming the Pages backwards and forwads. Koyal sio. $2 s$.

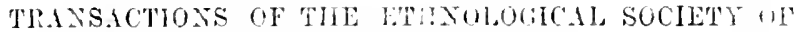

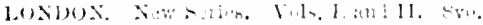

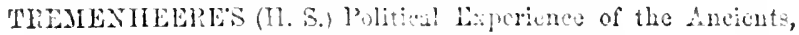

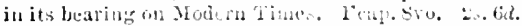

TRISTRAM (il. B.). Pine Great salutr. Wanderings South of the

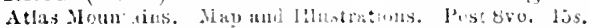

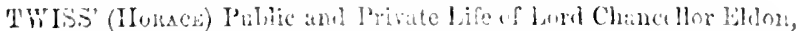

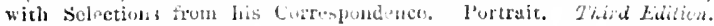
2 Fols. l'ost sro. 2ts.

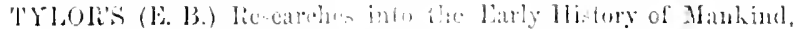

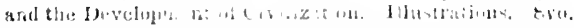

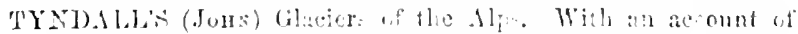

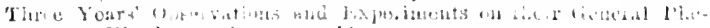

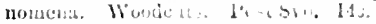

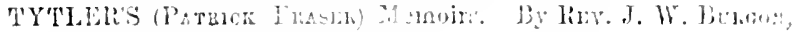
3... bro. 9.

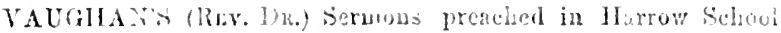
Evo. 1 , 6.

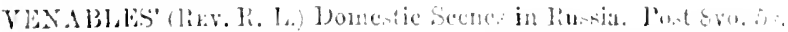

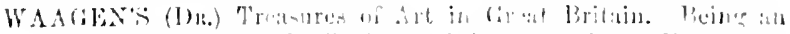

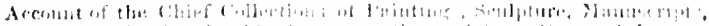

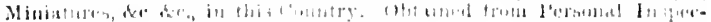

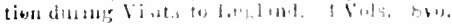

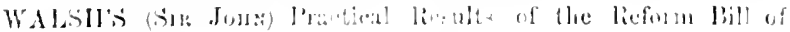

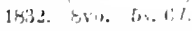

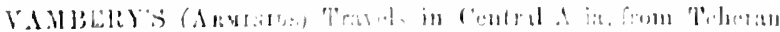

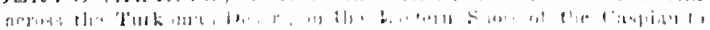

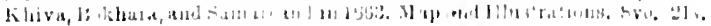


WELLINGTON'S ('The Duke of) Despatches during his rarious Campaigns. Compiled from ofticial and other Anthentic Bocuments. By Cor. Gerwood, C.B. 8 Vols. svo. 21s, each.

Supplementary Despatehes, and other Paper: Edited by his Son. Vois. I, to XIl, Svo. 20s. each.

Selections from his Despatehes and Gencral Orders. By Coloner Gurtiono, Sro. 1ss.

Speches in Parliament. 2 Vols. 8vo. $42 s$.

WilkINSON:S (SrR J. G.) Popuiar Account of the Private Life, Manners, and Customs of the Ancient Egyptians. Sto Edition. Revised and Condensel. With 500 Woodcuts. 2 Yols. Post sro. 12s.

Irandbook for Egypt.-Thebes, the Nile, Alex. andria, Cairo, the Pyramids, Monut Sinai, \&e. Map. Post Sro. 15.

(G. B.) Working Man's Handbook to South Au i. tralia; with Advice to the Farmer, and Detailed Information for the several Classes of Labourers and Artisans. Map. 1Smo. 1s. 6d.

irllsoN'S (Brshop Daniet) Life, with Extracts from his Letters and Journals. By Rev. Josma Eateman. Netomd Edition. Illustratious, Post Ser. 9 .

(GENL. SIR RoBERT) Seeret History of the French Invasion of Rilsia, and Letrext of the French Army, 1812. Second Editicn. 8vo. 15e.

- Private Diary of Travels, Personal Services, anel Public Events, during Missions and Employments in Spain, Sicily, Turkes, Russia, Poland, Germany, \&c. 1812-11. 2 Vols. Sro. 26.

Autobiographieal Memoirs. Containing an Aceount of lifs Early Life dowin to the Peace of Tilsit. Puttrait. 2 Yols. Ssu. $26 \%$.

HondSWORTH'S (CAYON) Journal of a Tour in Athens and Attica. Third Edition. Plates. Post Svo. Ss.6d.

Pietorial, Descriptive, and Historica! lccunt if Greece, with a Ifistory of Greek Art, by G. Scmin, I. Edition. With 600 woodents. Royal sro. 2Ss.

NoI? NUM (Ratph). A B́ographical Dictionary of Italian Painters: witly a Tahle of the Contemporary Schools of Itals. is a Lais. Post Evo. is. tid. 

UNIVERSITY OF CALIFORNIA LIBRARY

\section{Los Angeles}

This book is DUE on the last date stamped below.

\section{RECEIVED}

AUG 171983

CIRC. DEPT. URL 


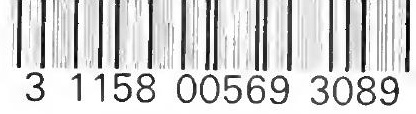

UC SOUTHERN REGIONAL LIBRARY FACILITY

\|\|$|\|||||||||||||||||||||||| \mid$ AA $001053655 \quad 5$ 
